UNIVERSIDADE DE SÃO PAULO

ESCOLA DE ENFERMAGEM

BÁRBARA BARRIONUEVO BONINI

SER ENFERMEIRO NEGRO NA PERSPECTIVA DA

TRANSCULTURALIDADE DO CUIDADO

São Paulo

2010 
Bárbara Barrionuevo Bonini

\section{SER ENFERMEIRO NEGRO NA PERSPECTIVA DA TRANSCULTURALIDADE DO CUIDADO}

Dissertação apresentada à

Escola de Enfermagem da

Universidade de São Paulo para obtenção do título de Mestre em Ciências. Área de Concentração: Fundamentos e Práticas de Gerenciamento em Enfermagem e em Saúde.

Orientador: Prof. Dr. Genival Fernandes de Freitas

São Paulo 
AUTORIZO A REPRODUÇÃO E DIVULGAÇÃO TOTAL OU PARCIAL DESTE TRABALHO, POR QUALQUER MEIO CONVENCIONAL OU ELETRÔNICO, PARA FINS DE ESTUDO E PESQUISA, DESDE QUE CITADA A FONTE.

Assinatura:

Data:

\section{Catalogação na Publicação (CIP)}

Biblioteca "Wanda de Aguiar Horta"

Escola de Enfermagem da Universidade de São Paulo

Bonini, Bárbara Barrionuevo

Ser enfermeiro negro na perspectiva da transculturalidade

do cuidado / Bárbara Barrionuevo Bonini. -- São Paulo, 2010.

184 p. : il.

Dissertação (Mestrado) - Escola de Enfermagem da Universidade de São Paulo.

Orientadora: Prof. Dr. Genival Fernandes de Freitas

1. História da enfermagem 2. Enfermagem Transcultural

3. Racismo 4. Negros 5. Cuidados em Enfermagem - Cultura 
Nome: Bárbara Barrionuevo Bonini

Título: Ser Enfermeiro Negro na Perspectiva da Transculturalidade do Cuidado.

Dissertação apresentada à

Escola de Enfermagem da

Universidade de São Paulo

para obtenção do título de Mestre em Ciências.

Aprovado em:

Banca Examinadora

Prof. Dr. Instituição:

Julgamento:

Assinatura:

Prof. Dr.

Instituição:

Julgamento:

Assinatura:

Prof. Dr. Instituição:

Julgamento: Assinatura: 


\section{DEDICATÓRIA}

Dedico este trabalho à minha família.

Ao meu irmão, Arthur, pela amizade, carinho e companheirismo. Para que ele nunca se esqueça que os sonhos, por mais impossíveis que possam parecer, se tornam realidade quando trabalhamos duro e não perdermos a fé.

Aos meus pais, César e Sueli, por terem me ensinado as lições mais valiosas da vida e por estarem sempre presentes, longe ou perto, comemorando cada conquista e me ajudando a levantar e seguir em frente após cada derrota.

Aos meus avós, Antônio e Eny, que nos ensinaram que o amor é algo incondicional e paciente, mesmo quando demoramos a aparecer nos almoços de domingo. 


\section{AGRADECIMENTOS}

A Deus, pelo dom da vida, pelas graças concedidas todos os dias e pelas oportunidades que me permitiram chegar até aqui.

À minha família, Pai, Mãe, Tutui, Nono, Vó, Ana, Haidy, Kaká, Bella e Má, pelo amor, pelo carinho e por serem minhas pessoas favoritas no mundo!

Ao querido Professor Genival, pela oportunidade de realizar esse trabalho, pelas tardes de orientação e pelo apoio nessa caminhada. Obrigada pela paciência, pelo incentivo e por acreditar que eu conseguiria.

À professora Taka, pela oportunidade de iniciar minha trajetória na pesquisa e pelo incentivo constante.

Ao professor Paulo Fernando, responsável pelo meu encantamento com a temática, pelas valiosas dicas e orientações ao longo desses 4 anos. Às companheiras, Márcia e Alessandra, pelos conselhos, pelas viagens e por mostrarem que era possível.

Aos meus queridos Rafael e Paulo Henrique, que mesmo sem entender direito o que eu vinha fazendo, estiveram sempre presentes, com seus sorrisos sinceros e seus abraços acolhedores.

Às grandes amigas, Helo e Dani, pela amizade, pelos desabafos e pelo companheirismo. Tenho certeza que continuaremos juntas em nossas caminhadas. 
À minha amiga Carol, que mesmo estando longe, teve um papel fundamental nessa etapa da minha vida. Obrigada por não desistir de mim, amiga!

À querida amiga Bruna (Duda), pelo apoio, pela disponibilidade e pela excepcional revisão textual.

A todos os colaboradores dessa pesquisa, por suas valiosas entrevistas e pela oportunidade de entender o racismo a partir de diferentes pontos de vista.

Aos membros do Grupo de Pesquisa "História e Legislação da Enfermagem”, pelas dicas, pelas discussões e por todo o aprendizado. 
"Ninguém nasce odiando outra pessoa pela cor de sua pele, ou por sua origem ou sua religião. As pessoas precisam aprender para odiar e, se elas podem aprender a odiar, podem ser ensinadas a amar, pois o amor chega mais naturalmente ao coração humano do que o seu oposto."

(Nelson Mandela) 
Bonini, B.B. Ser Enfermeiro Negro na Perspectiva da Transculturalidade do Cuidado. [Dissertação]. São Paulo (SP): Escola de Enfermagem, Universidade de São Paulo; 2010.

\section{RESUMO}

O presente estudo teve como objetivo central descrever questões da identidade do ser enfermeiro negro formado pela Escola de Enfermagem da Universidade de São Paulo, a partir da perspectiva da Teoria da Enfermagem Transcultural através da análise de situações de preconceito vividas por esses enfermeiros frente a sua escolha profissional, sua formação acadêmica e a sua inserção no mercado de trabalho. Por ser o presente trabalho de natureza descritiva, histórico-social e exploratória, optouse pelo método da História Oral, que é um método de pesquisa que utiliza a técnica da entrevista e outros procedimentos articulados entre si, no registro de narrativa da experiência humana. Optou-se também pelo método da História Oral Temática pelo fato desse ser um método que possibilita que as pessoas falem livremente, em seus respectivos contextos. A Escola de Enfermagem da USP formou, no período de 1947 a 2006, 2.886 enfermeiros, dos quais, 128 se declararam como não brancos. Foram localizados, no estado de São Paulo, 45 dos acima identificados, dos quais 14 cederam entrevistas para a presente investigação. Pode-se observar que a terminologia "moreno(a)" foi a mais utilizada para a autodeclaração e que, dos entrevistados, todos afirmam ter sofrido preconceito racial em algum momento de suas trajetórias de vida, em especial de forma velada, forma essa mais difícil de ser enfrentada. A presente investigação propiciou fazer da História uma atividade mais democrática a cargo das próprias comunidades, uma vez que permitiu construir a História a partir das próprias palavras daqueles que a vivenciaram e que participaram de um determinado período, mediante suas referências e, também, do seu imaginário, possibilitando o registro de reminiscências das memórias individuais ou a reinterpretação do passado.

PALAVRAS-CHAVE: História da Enfermagem, Cuidado Transcultural, Racismo, Negros, Cuidados em Enfermagem - Cultura. 
Bonini, B.B. Being Black Nurses in the Transcultural Care Perspective. [Dissertation]. São Paulo (SP): Escola de Enfermagem, Universidade de São Paulo; 2010.

\begin{abstract}
This study aimed to describe the central issues of being a black nurse graduated by the School of Nursing, University of São Paulo, from the perspective of the Theory of Transcultural Nursing trough the analysis situations of prejudice experienced by these nurses facing their career choice, their academic training and their integration into the labor market. As the study has a descriptive, historical, social and exploratory character, was chosen the method of Oral History, which is a method that uses the interview and other processes linked together in the narrative record of human experience. It was also chosen the method of Oral History Thematic considering the fact that this method helps people to speak freely in their respective contexts. The School of Nursing graduated, in the period of 1947 to 2006, 2,886 nurses, of which 128 identified themselves as non-whites. Located, in the state of São Paulo, 45 of the above identified, of which 14 were interviewed for this research. It was noted that the terminology "moreno" was the most used for self reporting and that of those interviewed, all stated have suffered racial discrimination at some point in their life trajectories, especially in hidden form, which is the harder form to face. This research led to a more democratic history over the view of its own communities, because it allows the construction of history from the very words of those who participated and experienced, in a given period of time, through its references and imagination, allowing the registration of reminiscences of individual memories or the reinterpretation of the past.
\end{abstract}

KEYWORDS: History of Nursing, Transcultural Care, Racism, Black, Cultural Care. 


\section{LISTA DE ILUSTRAÇÕES}

FIGURA 1 Ficha de Inscrição de Josephina de Mello: Modelo das primeiras fichas.

FIGURA 2 O Processo de Enfermagem segundo Wanda 42 Horta.

FIGURA 3 The Sunrise Enabler, por Madeleine Leninger. 46

FIGURA 4 Representação da Medicina Antropométrica 52

FIGURA 5 Propaganda contra o Racismo, Ministério da 88 Saúde.

GRÁFICO 1 Declaração étnica dos egressos "não brancos" da 29 EESUP, no período de 1947 a 2006.

GRÁFICO 2 Número de alunos "não brancos" formados no 30 período de 1947 a 2006.

GRÁFICO 3 Alunos de diferentes nacionalidades formados no período de 1947 a 2006.

GRÁFICO 4 Alunos brasileiros provenientes de diferentes Estados, no período de 1947 a 2006.

GRÁFICO 5 Caracterização dos alunos "não brancos" quanto ao gênero, no período de 1947 a 2006. 


\section{LISTA DE SIGLAS}

ABEN - Associação Brasileira de Enfermagem.

CEP - Comitê de Ética em Pesquisa.

CNPq - Conselho Nacional de Desenvolvimento Científico e Tecnológico.

COFEN - Conselho Federal de Enfermagem.

COREN - Conselho Regional de Enfermagem.

EEUSP - Escola de Enfermagem da Universidade de São Paulo.

ICN - International Council of Nurses.

IPEA - Instituto de Pesquisa Econômica Aplicada.

PSF - Programa de Saúde da Família.

RAIS - Relação Anual de Informações Sociais.

SESP - Serviço Especial de Saúde Pública.

SUS - Sistema Único de Saúde.

UBS - Unidade Básica de Saúde.

USP - Universidade de São Paulo.

UTI - Unidade de Terapia Intensiva. 
SUMÁRIO

1 INTRODUÇÃOO 14

2 OBJETIVOS 22

3 CONTEXTO HISTÓRICO DA ESCOLA DE 23 ENFERMAGEM DA UNIVERSIDADE DE SÃO PAULO (EEUSP)

3.1 O Negro na Escola de Enfermagem da USP 25

4 METODOLOGIA 35

4.1 Referencial Metodológico 35

4.2 Percurso Metodológico 37

5. REFERNCIAL TEÓRICO 40

5.1 A Transculturalidade do Cuidado 40

6 A CONFIGURAÇÃO DO RACISMO 50

7 PERFIS DOS COLABORADORES

8 RESULTADOS E ANÁLISE DOS ACHADOS 71 REFERENTES AOS DISCURSOS DOS COLABORADORES

8.1 Preconceito face à Escolha Profissional 71

8.2 Preconceito durante o processo de Formação Acadêmica $\quad 74$

8.3 Preconceito na Inserção Profissional 81

9 CONSIDERAÇÕES FINAIS 90

REFERÊNCIAS 93

APÊNDICE 1 - Termo de Consentimento Livre 98 Esclarecido

APÊNDICE 2 - Instrumento de Coleta de Dados 100

APÊNDICE 3 - Entrevistas 102

ANEXO A - Parecer do Comitê de Ética em Pesquisa 183

ANEXO B - Autorização para Coleta de Dados 184 


\section{INTRODUÇÃO}

É comum se dizer que a Enfermagem surge quando um de seus maiores ícones, Florence Nightingale, escreve um livro chamado "Notas sobre Enfermagem" (1859), no qual discorre não somente sobre a prática da enfermagem, mas sobre a formação da identidade da enfermeira.

Ao confrontar esta obra de Florence Nightingale com a de José Bueno e González (El arte de Enfermería, 1833), Chaverri (1995) considera que esta última consiste em um tratado com critérios enciclopédicos, mais empíricos e, ainda, com vislumbres de filosofia, metafísica e política assistencial. Porém, Chaverri destaca que tanto a obra de Nightingale (1859), quanto a de González (1833), apresentam evidências importantes na direção do desenvolvimento da enfermagem como ciência. A evidência encontra-se, segundo Chaverri, centrada na observação subjetiva do paciente, dos sinais e sintomas, e também nas intervenções da enfermeira em diversas dimensões do ser humano, seja no físico, no espiritual, ou no tocante ao cuidado com o ambiente terapêutico, a fim favorecer a recuperação da saúde. A segunda evidência está centrada na filosofia e na práxis de enfermagem, ou seja, a missão do serviço de enfermagem, no contexto do século XIX, sendo detalhista na descrição de técnicas ou ações assistenciais.

A versão mais atualizada da obra original de Florence Nightingale foi apresentada pelo Conselho Internacional de Enfermeiras (ICN), em 2009, intitulada "Notes on nursing: a guide for today's caregivers", como parte de uma política dessa instituição para ajudar a manter o alto nível da enfermagem nas diversas realidades mundiais, promovendo uma assistência de enfermagem à clientela pautada na educação, nos aspectos legais inerentes a cada país e por meio da organização profissional (ICN, 2009).

Entretanto, sabemos que a prática da enfermagem surge muito antes de 
Florence, com as mulheres da Grécia antiga que, ao viverem em um estado de completa alienação dos processos de discussão, que só cabiam aos homens, dedicavam-se ao cuidado de seus filhos, maridos e dos doentes, tornando-se, assim, as primeiras "médicas" e "anatomistas" da história ocidental. Essas mulheres realizavam partos, abortos e tratavam os doentes com plantas e ervas medicinais. (Borenstein, 1998). Deste modo, é possível dizer que as mulheres gregas da antiguidade clássica foram as primeiras "enfermeiras" da nossa história.

Na idade média, as práticas de cuidar eram atribuídas às mulheres mais idosas e mais experientes, responsáveis pelo cuidado dos doentes e principalmente pelo parto, cujo valor implicava na garantia da perpetuação e sobrevivência do grupo. Nos períodos subsequientes, religiosas que se dedicavam a cuidar daqueles que eram abnegados, loucos, pobres e doentes, davam à enfermagem um aspecto de doação e dedicação caridosa, como um ato sagrado, distanciando a prática do cuidado como profissão, inclusive porque o trabalho das mulheres estava restrito à manutenção do lar e educação dos filhos, ou seja, restrita ao espaço doméstico.

Com o advento das Cruzadas, a atividade de cuidar passou a ser atribuída aos homens, monges das ordens militares, que moldaram a formação dos primeiros enfermeiros. Após esse período, no século XVI, com a reforma religiosa na Inglaterra em que Henrique VIII permite a criação da Igreja Anglicana, a enfermagem passa por um processo identificado como: estagnação e desqualificação, pois sua prática passa a ser vinculada a mulheres socialmente decadentes, na maioria dos casos, analfabetas e inescrupulosas.

Esse período foi imortalizado pelo escritor Charles Dickens (1812-1870) ao criar a imagem de Sairey Gamp, que representa a mulher que cuidava como uma mulher gorda, viciada, mercenária, com desvios de caráter (Souza Campos, Oguisso, 2008 apud Miranda, 1996), generalizando uma imagem que encobre a miséria e pobreza que assolavam as grandes cidades européias como Londres e Paris. As 
mulheres pobres, viúvas e desenraizadas encontraram na prática de cuidar uma forma de manter suas vidas, ainda que desprestigiadas.

A enfermagem ressurgiu com imagem nova, humana, moderna e científica pelas mãos de Florence Nightingale, que elevou o cuidado a um patamar aristocrático, nobre, definindo-a como uma prática necessária, que poderia e deveria ser exercida como uma profissão digna. A condição social da fundadora da enfermagem moderna, assim como outras mulheres que viveram a passagem do século XIX para o século XX, que se dedicaram na ação de cuidar, abriu novas perspectivas para as mulheres, alterando as condições sociais imputadas a elas até aquele momento.

Sendo assim, é possível afirmar que essa prática esteve sempre associada ao cuidado com o outro. A palavra enfermagem vem do latim "infirmus", que significa aquele que não está firme: o doente, a pessoa idosa e o inválido. Porém, esse termo adquiriu um sentido mais amplo, abrangendo também a conservação e a promoção da saúde daqueles que estão sãos, os lugares nos quais vivem, moram e trabalham, seus comportamentos e significativamente a cultura da qual emergem. (Stewart, Dock, 1977).

Reconhecida hoje como uma profissão, ou seja, "um trabalho especializado, regulamentado por lei, desempenhado mediante remuneração salarial, possuindo uma associação de classe, uma revista profissional e um Código de Ética", a enfermagem constitui importante campo de conhecimento e pesquisa não apenas biológica, mas social. (Stewart, Dock, 1977, p.83).

Todavia, ainda é caracterizada como uma atividade técnica e manual, sem grandes ganhos no campo intelectual. Essa imagem elimina as teorias de enfermagem, nas quais se baseiam o cuidado e sua sistematização, como as que 
ressaltam a cultura do indivíduo cuidado e do cuidador e suas inserções sociais, demonstrando que a enfermagem, desde sua origem, possui cabedal intelectual, que permite seu desenvolvimento ao longo do século, firmando cada vez mais a profissão no universo social. (Oguisso et al, 1999)

Ainda assim, parte da história dessa profissão revela que, desde a época de Florence Nightingale, diferentes formas de preconceito são vivenciadas dentro da enfermagem. Em relação à seleção dos candidatos à profissão, tínhamos uma experiência pautada no racismo e sexismo, na medida em que o modelo de formação/ensino impedia a inclusão de mulheres negras, e de homens de qualquer etnia, nos quadros discentes das escolas que adotavam o padrão proposto pela precursora da enfermagem moderna. Assim sendo, as escolas de enfermagem no Brasil que assumiam o modelo nightingaleano não admitiam mulheres negras e tampouco homens, esses brancos ou negros, na formação profissional, extra ou oficialmente instituída.

Segundo estudos, Florence Nightingale foi acompanhada durante seus trabalhos na guerra da Criméia por uma enfermeira negra chamada Mary Grant Seacole, que foi impedida de frequientar a Escola dirigida por Miss Nightingale (Cruz, Sobral, 1995). Esse tipo de atitude nos leva a pensar que as características físicas e sociais se sobrepunham as competências dessas candidatas, para que, assim, se pudesse manter um padrão, uma imagem, do que seria socialmente mais aceito dentro do contexto histórico ao qual estavam inseridos os sujeitos.

Hoje em dia, reconhece-se um grande número de negros que atuam como enfermeiros, auxiliares ou técnicos na assistência hospitalar, além daqueles que são doutores e/ou professores titulares em Escolas de Enfermagem do Brasil. Contudo, salienta-se o fato de termos pouco conhecimento das pessoas que abriram os caminhos para que isso fosse possível, além de desconhecermos a história de vida dessas pessoas e a representação social diante à profissão e às situações de racismo 
no âmbito da profissão nos sistemas de saúde (Cruz, Sobral, 1995). A existência de grupos de estudo ou publicações sobre o tema desta pesquisa se restringem a poucos trabalhos, muitas vezes de caráter interdisciplinar, característico da História da Enfermagem.

Com nossa história de aproximadamente 400 anos de escravidão negra, e pouco mais 100 anos de abolição da escravatura, e dada à condição deste grupo étnico na sociedade brasileira contemporânea, é necessário questionarmos sobre os por quês da exclusão/inclusão dos negros na sociedade. Isso aponta para o estudo do processo de inclusão social e acesso a níveis de educação universitária desses remanescentes de escravos e seus descendentes, e com isso as possíveis condições de melhoria do trabalho e estrutura socioeconômica igualitárias.

Por esse motivo escolhemos a temática pretendendo identificar quais foram as dificuldades percebidas pelos alunos negros da Escola de Enfermagem da Universidade de São Paulo, no período de escolha profissional, durante suas trajetórias acadêmicas e no processo de inserção profissional no mercado de trabalho. Sendo assim, a motivação para a realização desse estudo é conhecer como se deu, historicamente, essa inserção do negro na enfermagem brasileira, particularmente na Escola de Enfermagem da Universidade de São Paulo, propiciando a discussão dessa temática a partir da ótica dos enfermeiros negros.

Crê-se que, para entender o processo de mudança e transformação dessa trajetória vivida pelos egressos negros, é necessário dar voz aos protagonistas da história para que se possa refletir melhor sobre a identidade profissional desse grupo que, muitas vezes esquecido, faz parte da identidade da profissão como um todo.

A compreensão histórica e cultural vivida pela imensa maioria dos negros no Brasil permite recuperar, da mesma forma, a história da enfermagem no 
nosso país. A enfermagem nacional oficial recupera a fundação da Escola de Enfermeiras Anna Nery, no Rio de Janeiro, com a importação do modelo e teoria da enfermagem utilizada nos Estados Unidos, de origem nightingaleana, que deveria ser adotado pelas demais escolas brasileiras. (Coelho, 1997; Barreira, 2005). Contudo, estudos recentes revelam, ainda que extra-oficialmente, que o primeiro núcleo formador da enfermagem nightingalena no Brasil pode ser atribuído à Escola de Enfermagem do Hospital Samaritano, em São Paulo, tal qual preconizado, ou seja, vinculado a um hospital, sem caráter acadêmico (Mott, 1999; Oguisso, 2007; Carrijo, 2007).

Nesse caso, ao se referir à origem e ao ingresso das primeiras alunas na Escola de Enfermagem Anna Nery, destaca-se que esse ingresso passou a depender não só da posse do diploma do curso normal, mas também de um pré-requisito não formalizado que a candidata fosse de "raça branca". Tentou-se assim barrar o acesso à profissão não apenas das mulheres originárias das classes menos favorecidas, como àquelas oriundas do contingente populacional majoritário de negros e mestiços (Moreira, 1999). Cabe ressaltar um incidente ocorrido já na primeira turma, em que uma aluna teria sido impedida de se matricular por ser negra e, assim, permitir que a escola estabelecesse uma imagem mais "branca" da enfermagem. O fato tomou notoriedade e trouxe à público uma realidade que viria desvelar a questão da discriminação racial na enfermagem. Após o incidente, o acesso da candidata foi garantido, sob protesto das colegas e com a condição estipulada pelas próprias alunas de que não mais se permitiria o acesso de estudantes negras. Em seu estudo, Moreira, aponta:

"É verdade que a política de organização da escola (Anna Nery) tinha sido evitar, diplomática e estrategicamente, a admissão de negros, até que a opinião pública em relação à profissão de enfermagem tivesse mudado. Isto era fundamental se pretendia atrair mulheres de melhor classe... Mesmo a Academia naval colocava diversos obstáculos para impedir a admissão de candidatos negros. Todas as vezes que as moças de cor se candidatavam a entrar na escola, havia sempre outras boas razões para que elas não fossem qualificadas, por isso nenhum problema havia surgido até então. Na verdade, havia já na escola três estudantes que, apesar de brancas, mostravam alguns traços de sangue negro. Foi enviada uma carta à imprensa comunicando que nenhuma pretendente havia sido rejeitada por causa da cor, mas não foi 
convincente, e o Departamento de Saúde achou que seria aconselhável permitir o ingresso de uma moça negra, se acaso se apresentasse alguma que preenchesse todos os requisitos para admissão. Esta candidata apareceu em março, juntamente com as demais pretendentes, sob forte suspeita de que havia sido enviada por um dos jornais, e foi admitida. Isto provocou uma enxurrada de protestos por parte das alunas, mas, após considerar a questão, o Conselho de Estudantes finalmente decidiu que qualquer manifestação de rejeição ou de descortesia para com uma colega de classe demonstraria falta de respeito e de vontade de cooperar, e assim não houve mais dificuldades. As estudantes deixaram claro, contudo, que esperavam que não fosse admitida nenhuma outra negra por algum tempo." (Moreira, 1999, apud Miner, 1925, p. 628)

Não só as alunas brasileiras foram alvo desta "vigilância racial". Tal fato aconteceu também com as enfermeiras norte-americanas. A vinda de uma enfermeira descrita como mestiça (half breed) ao Brasil, foi considerada como inconveniente ante a possibilidade de não ser bem aceita no Brasil (Moreira, 1999).

Santos (2004) ressalta que as documentações da Fundação Rockefeller, que participou da institucionalização da pesquisa experimental no país, e apoiou a fundação e formação de profissionais na área da saúde, principalmente enfermeiras, sugerem que, a mesma, agiu tendo em vista propiciar a mobilidade e a ascensão do profissional negro. Entretanto, isso se deu, apenas, depois dos primeiros tempos de formação dos quadros dirigentes.

Em consonância com os debates propostos, o texto "Exclusión de mujeres negras. Su Representación en la Enfermeria Profesional" (Souza Campos, Oguisso, 2006) nos leva a refletir que a história da enfermagem é também a história da mulher brasileira, pois as mulheres foram excluídas dessa história devido ao sexismo existente na época. Sendo assim a mulher negra foi duplamente segregada, já que afrodescendentes eram considerados desqualificados ou impróprios para determinadas profissões, com acentuado destaque para a profissão de enfermagem na medida em que as representações do negro no Brasil os identificavam como indolentes, marginais, imagens contrárias às requeridas pelo padrão proposto como ideal, qual seja, moças brancas, filhas das elites. Portanto, estudar esse processo de exclusão e inclusão da mulher negra na enfermagem, de acordo com os autores, 
torna-se fundamental para o estudo da formação da identidade profissional da enfermagem brasileira.

Acredita-se então que entender a história da enfermagem é algo que vai além da simples curiosidade, pois permite que cada enfermeiro possa orientar e influenciar o futuro de sua profissão, tornando-os capazes de avaliar e julgar corretamente acontecimentos atuais que afetam a sua própria carreia. (Stewart, Dock, 1977).

Sendo assim, esse trabalho se torna relevante para que se possa, a partir da investigação científica, direcionar o olhar dos enfermeiros para o preconceito por eles exercido, e também sofrido, de forma a fazê-los perceber que há uma necessidade de mudança na arte de se realizar o cuidado e o ensino de enfermagem, ampliando o olhar e fortalecendo a profissão. 


\section{OBJETIVOS}

A partir das inquietações apresentadas, e das sugestões dadas durante o exame de qualificação, delimitaram-se os seguintes objetivos para a pesquisa em questão:

- Identificar o perfil sócio demográfico de enfermeiros negros formados pela Escola de Enfermagem da Universidade de São Paulo, no período de 19422006.

- Identificar os processos históricos que possibilitaram movimentos de exclusão e inclusão dos enfermeiros negros formados pela EEUSP, no período citado, a partir da perspectiva da Teoria da Enfermagem Transcultural.

- Analisar as situações de preconceito vivenciadas pelos enfermeiros negros face à escolha profissional, sua formação acadêmica e sua inserção no mercado de trabalho por intermédio da oralidade. 


\section{CONTEXTO HISTÓRICO DA ESCOLA DE ENFERMAGEM DA UNIVERSIDADE DE SÃO PAULO (EEUSP)}

Com a sua criação, em 1942, a Escola de Enfermagem da Universidade de São Paulo, favoreceu decisivamente a reconfiguração da identidade da enfermagem profissional brasileira.

Segundo Souza Campos (2008) é possível afirmar que a criação da Escola constituiu parte importante de um acordo governamental entre Brasil e Estados Unidos, cujas origens remontam o processo de institucionalização da ciência aplicada no Brasil. As cidades de Rio de Janeiro e São Paulo foram os centros das aplicações financeiras oriundas desses acordos. Ainda que distintos, os acordos foram intermediados por instituições como, Instituto de Assuntos Interamericanos e Fundação Rockefeller a partir dos anos 1920 e Fundação Kellogg, esta última acentuadamente no pós-30, com concessões de Bolsas de estudo para as "enfermeiras profissionais", destacadamente as enfermeiras formadas pela Escola de Enfermagem da Faculdade de Medicina da Universidade de São Paulo.

No projeto de criação da EEUSP constava um memorial escrito pela enfermeira Mary E. Tennant (1940) ${ }^{1}$, representante da Fundação Rockefeller, com as especificações das estruturas física necessárias para abrigar a Escola e a residência das alunas, professoras e enfermeiras do Hospital das Clinicas, e a parte do ensino deveria ser baseado na mais moderna literatura norte-americana da época, notadamente o livro "A curriculum guide for School of Nursing”.

\footnotetext{
${ }^{1}$ Tennant ME. Relatório de Sugestões de Miss Tennant. Junho de 1940. Sobre a organização e desenvolvimento da educação em enfermagem em São Paulo. Disponível no acervo da Faculdade de Medicina da Universidade de São Paulo - FMUSP.
} 
Este relatório atendia a solicitação do então interventor do Estado, Sr. Ademar de Barros, o qual requeria um parecer técnico acerca das condições para a organização e desenvolvimento da educação em enfermagem em São Paulo e a premente necessidade de enfermeiras para a atuação hospitalar, em especial após a inauguração do Hospital das Clínicas da Faculdade de Medicina da Universidade de São Paulo, em 1944, considerado até os dias atuais como o maior complexo hospitalar da América Latina.

A Escola de Enfermagem da Faculdade de Medicina da Universidade de São Paulo, como era chamada, iniciou suas atividades em 02 de janeiro de 1943, sob a direção de Edith de Magalhães Fraenkel, que à época também era Chefe do Serviço de Enfermagem do Hospital das Clínicas (Carvalho, 1980). Cabe pontuar que a Professora Edith de Magalhães Fraenkel, antes de assumir a direção da escola mencionada, atuou no Rio de Janeiro como assistente da enfermeira norte americana Ethel Parsons, junto ao Departamento Nacional de Saúde Pública. Estas duas enfermeiras tiveram um papel decisivo na organização e dinamização da denominada “Associação Nacional de Enfermeiras Diplomadas Brasileiras", inclusive tornando-a membro no Conselho Internacional de Enfermeiras, em 1929 (Secaf, Costa, 2007).

A Escola de Enfermagem da Faculdade de Medicina da Universidade de São Paulo fora organizada em torno da pesquisa científica e das novas demandas da enfermagem moderna, tendo seu ensino alcançado parte significativa do território nacional. A instituição abriu espaço para alunas provenientes de outros estados, em especial norte e nordeste, realizarem seus estudos e, posteriormente, voltarem a seus estados de origem para trabalharem nos serviços de saúde. Isso foi possível através da criação em 1942, do Serviço Especial de Saúde Pública (SESP), órgão executivo do acordo Brasil - Estados Unidos, financiado pela Fundação Rockefeller e Instituto de Assuntos Interamericanos, porém, subordinado ao Ministério da Educação e Saúde cuja missão era sanear regiões nas quais eram endêmicas a febre amarela e malária. O SESP contribuiu para o 
desenvolvimento e dinamização da enfermagem no Brasil (Souza Campos, Oguisso, 2008).

É importante ressaltar que a Escola, inicialmente, era vinculada à Faculdade de Medicina da USP, como o primeiro nome já sugere, porém funcionava como se fosse autônoma, com orçamento, direção e corpo docente qualificado próprio. Entretanto, essa vinculação impedia o desenvolvimento pleno da instituição, pois sua representação junto ao Conselho Universitário era feita através do diretor da Faculdade de Medicina, que nem sempre considerava as necessidades ou atendia as reivindicações da instituição. Para tanto, em dezembro de 1962, após quase 6 anos de tentativas, a Faculdade de Medicina concordou com a desvinculação da EEUSP e, através do Decreto Estadual n. 42.809, de 20-12-1963, tornando a escola se tornou um estabelecimento de ensino superior autônomo administrativamente e permanecesse dessa maneira até hoje. (Moreira, 2008; Souza Campos, Oguisso, 2008; Carvalho, 1980)

\subsection{O NEGRO NA ESCOLA DE ENFERMAGEM DA USP.}

Uma das primeiras negras na Escola de Enfermagem da USP apareceu nos registros no ano de 1943. Josephina de Mello, aluna da segunda turma, foi bolsista do Serviço Especial de Saúde Pública (SESP) e trabalhava num posto médico na cidade de Manaus, Estado do Amazonas, antes de ir a São Paulo realizar seus estudos (Souza Campo, Oguisso, 2008). Josephina se autodeclara "preta" em sua ficha de inscrição, uma das inúmeras maneiras de autodeclarações que constavam nas fichas de inscrição dos egressos.

A EEUSP formou 3.680 enfermeiros, no período de 1947 a 2006. Daquele contingente, 128 identificaram-se, na documentação consultada junto ao Serviço de Graduação da EEUSP, como "não brancos". Contudo, houve 
mudanças na ficha de inscrição dos alunos ao longo dos anos.

Assim, durante a década de 1940, ao ingressante da EEUSP era solicitado o preenchimento de uma longa ficha de inscrição na qual, entre outras informações, constavam dados pessoais e sócio-econômicos, cartas de recomendação, documentos institucionais como diplomas, certificados, transferências e outros registros do histórico-escolar, bem como local de procedência, atestados médicos e espaço para preenchimento de possíveis motivações que levaram o candidato à escolha da profissão de enfermagem e da escola, além de uma autodeclaração quanto à origem étnica. 


\section{FIGURA 1 - Ficha de Inscrição de Josephina de Mello: Modelo}

\section{das primeiras fichas.}

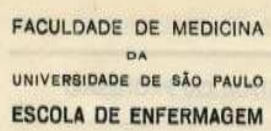

FACULDADE DE MEDICINA

UNIVERBIDADE DE São PAULO ESCOLA DE ENFERMAGEM

FOLHA DE ADMISSẢO

Esta folha, cuidadosamente preenchida, deverá dar entrada na Secretaria da Escola de Enfermagem, até 15 de Fevereiro ou 15 de Julho. Pedido algum será tomado om consideraçấo, se não estiver acompanhado dos documentos exigidos.

1- NOME fouphima de Wello

2- Residescia Rua Majór abriel 2186

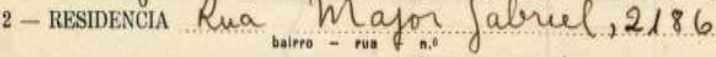

3 - DATA DO NASCIMENTO 21 de Maio de 1920

TEL. $14 \$ 3$

4-00R preta PESO 47 quilos ALTURA 1.55 RELIGIão protes tante

5 - ESTADo civil Solteira NACIONALIDADE frasileira

6 - NOME DO PAI Uuvencio Saulo de Wello DATA DE NASCIMENTO 10-1 - 1864 Enderęo Falecido

Nacionalidade Grasiluira Protissãofuncionário da Manaus Harbour Co Instrução

Se falecido, a causa mortis

$$
\text { Colapso cardiaco }
$$

7 - NOME DA Mã f lorence Qllbertha de Mello DATA DE NASCIMENTO $13-5-1898$

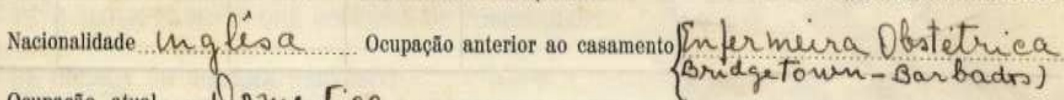

ocupação atual Domestiea.

Instruçâo primainia

Se falecida, a causa mortis

8 - CASO SEUS PAIS ESTEJAM SEPARADOS, OU NÃO VIVA COM ELES, O NOME DA PESSOA COM QUEM VIVE:

Residencia

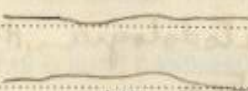

Pensão? Parente? Amigos?

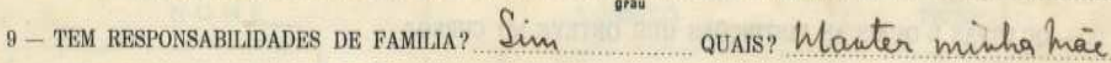

10 - QUAIS OS RECURSOS FINANCEIROS DE QUE DISPÓE PARA CUSTEAR AS DESPEZAS DO CURSO DE Enfermagem? Bolsa do Serrico ispacial de Saude fulblica.

11 - TERÅ DE RECORRER A EMPRESTIMO PARA COBRIR AS DESPEZAS DO CURSO?

E. E. 1

Fonte: Serviço de Graduação da Escola de Enfermagem da USP. 
Já em meados da década de 1950, houve a subtração do espaço dedicado às motivações da escolha pela profissão. Em 1961, houve nova mudança na ficha de inscrição para matrícula, desta vez, subtraindo o campo dedicado a autodeclaração étnica. Com nova mudança tornou-se necessário a verificação das certidões de nascimento nas quais era declarada a cor da pele do recémnascido. Cabe acrescentar, à vasta diversidade de naturalidades, algumas dessas certidões de nascimento não continham a informação sobre cor de pele.

No ano de 1964, aconteceu nova mudança nos registros acadêmicos da EEUSP. A partir desta data, antes de se formar, o estudante escolhia entre uma formação em Enfermagem Geral, Obstetrícia ou Saúde Pública. Dividida, as turmas agrupavam-se em três subgrupos. A partir de 1982, percebeu-se que as certidões de nascimento não possuíam mais a informação sobre cor, com isso, a análise da origem étnica dos egressos passou a ser feita através dos documentos fotográficos, anexos as fichas, exigidos no ato da matrícula.

A partir da década de 1990, o arquivo da sessão de alunos da EEUSP e as fichas de identificação de matrícula tiveram seus formatos alterados, tornando-se ainda menores que as de anos anteriores.

Observou-se que a etnia "morena" foi a mais escolhida entre os egressos para autodeclaração, seguida pela denominação "parda". Também foi discrepante o número de alunos não brancos formados no período de 1947 e 2006. 
GRÁFICO 1 - Declaração étnica dos egressos "não brancos" da EEUSP, no período de 1947 a 2006.

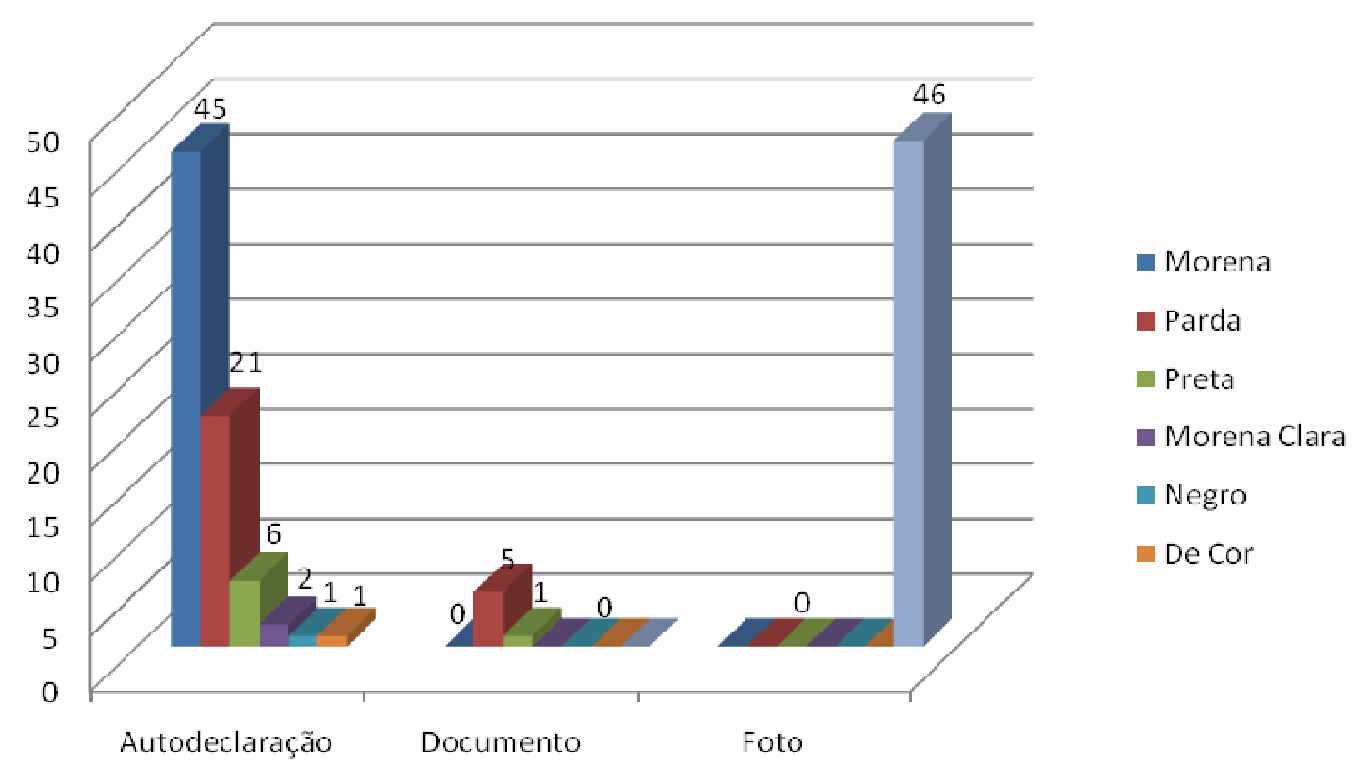

Fonte: Serviço de Graduação da Escola de Enfermagem da USP. 
GRÁFICO 2 - Número de alunos "não brancos" formados no período de 1947 a 2006.

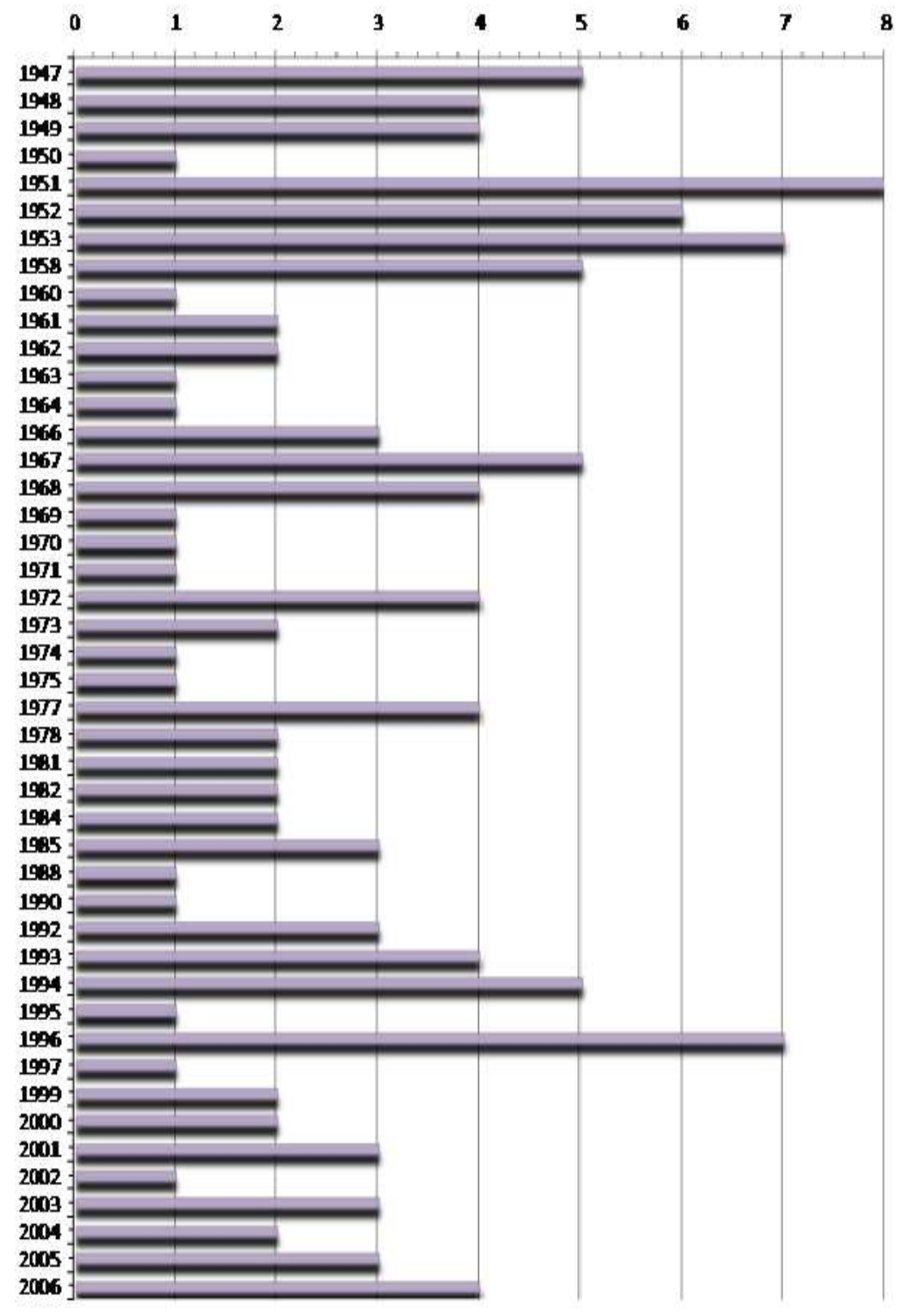

Fonte: Serviço de Graduação da Escola de Enfermagem da USP. 
É importante destacar também que, dos 128 alunos autodeclarados "não brancos" formados no período, 18 deles eram provenientes de outros países, mormente, de Angola. Dos 110 brasileiros, metade nasceu no Estado de São Paulo, enquanto os outros constam como nascidos em diferentes Estados. Vale ressaltar que 7 das fichas consultadas apresentaram egressos "não brancos" e sem a indicação do Estado onde nasceram.

No tocante à questão do gênero, observou-se que a quantidade de mulheres “não brancas' discentes da EEUSP, no período estudado, apresentou-se maior que o número de homens formados no mesmo período também identificados como "não brancos".

Segundo Costa e Freitas (2010), de um total de 36 homens formados na EEUSP, no período de 1950 a 1990, a maioria se autodeclarou pertencente à etnia branca (31), 2 se autodeclararam "morenos", 2 se autodeclararam pertencentes à etnia "amarela" e 1 se autodeclarou negro. Com isto, ditos autores entendem que a acessibilidade de homens "não brancos" ao curso de enfermagem na EEUSP, no período estudado, é significativamente baixa. 


\section{GRÁFICO 3 - Alunos de diferentes nacionalidades formados} no período de 1947 a 2006.

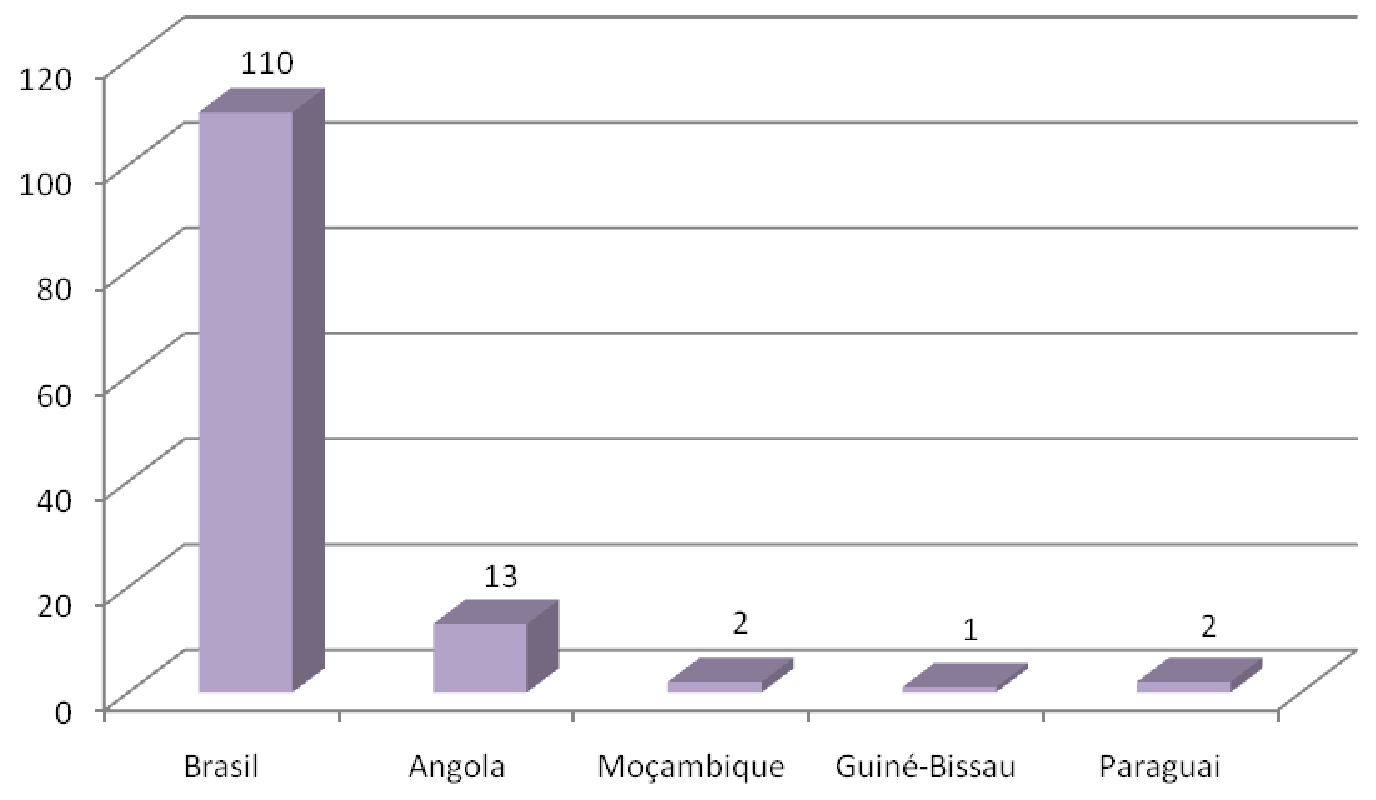

Fonte: Serviço de Graduação da Escola de Enfermagem da USP.

Quanto à nacionalidade dos formados no período de 1947 a 2006, podemos observar nos achados acima a influência e a participação da Escola de Enfermagem da USP para o processo de formação de gerações de enfermeiros, dentro e fora do território nacional, mormente no tocante aos países de língua portuguesa, como Angola, Moçambique e Portugal. 


\section{GRÁFICO 4 - Alunos brasileiros provenientes de diferentes} Estados, no período de 1947 a 2006.

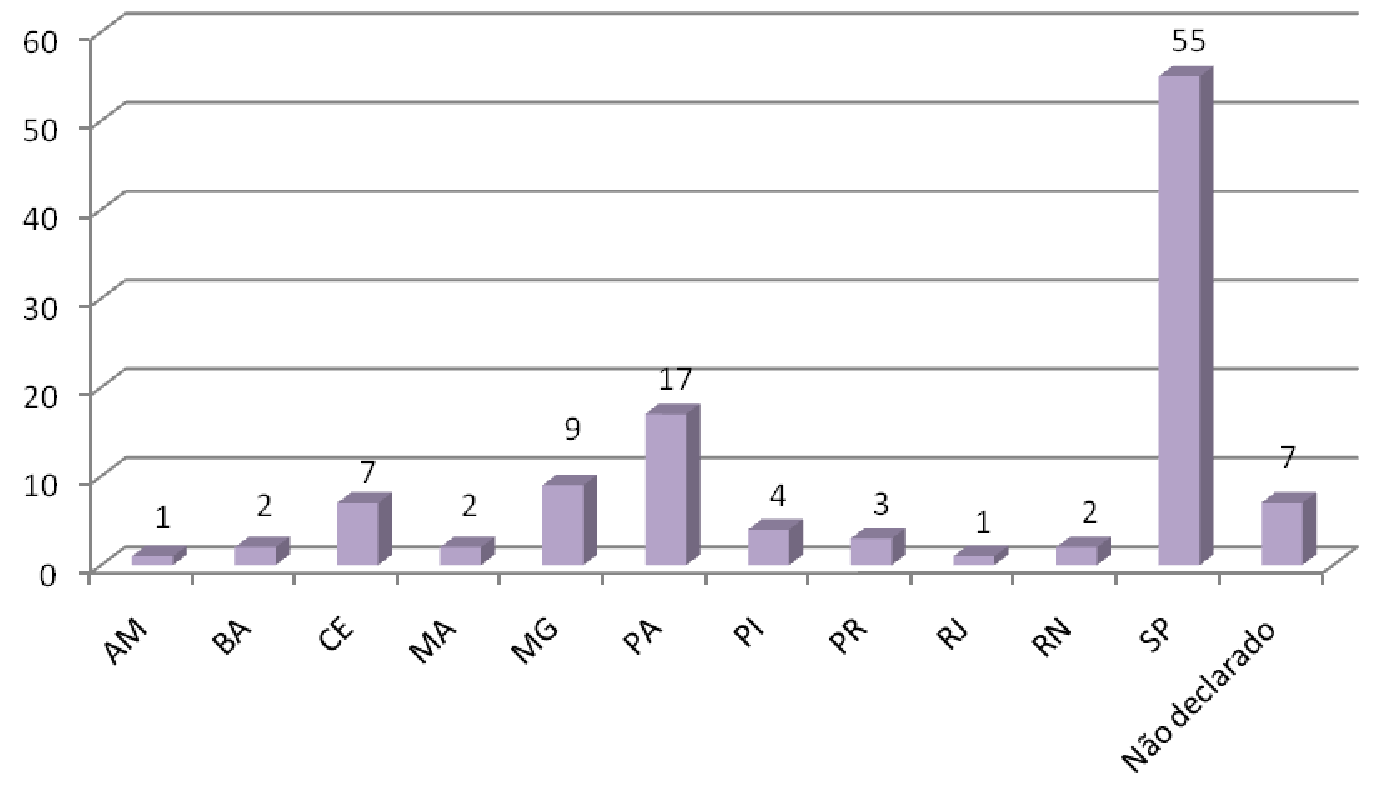

Fonte: Serviço de Graduação da Escola de Enfermagem da USP.

Os resultados acima estão em consonância com o estudo realizado por Costa e Freitas (2010), que ressaltou a distribuição do contingente de homens (enfermeiros) formados na Escola de Enfermagem da USP nas décadas de 1950 a 1990, segundo a procedência (ou região do Brasil) à época da admissão no curso de enfermagem. Assim, estes autores observaram uma predominância dos candidatos provenientes da região sudeste $(72,3 \%)$ de um total de 36 homens ingressantes na referida Escola. 


\section{GRÁFICO 5 - Caracterização dos alunos "não brancos" quanto ao gênero, no período de 1947 a 2006.}

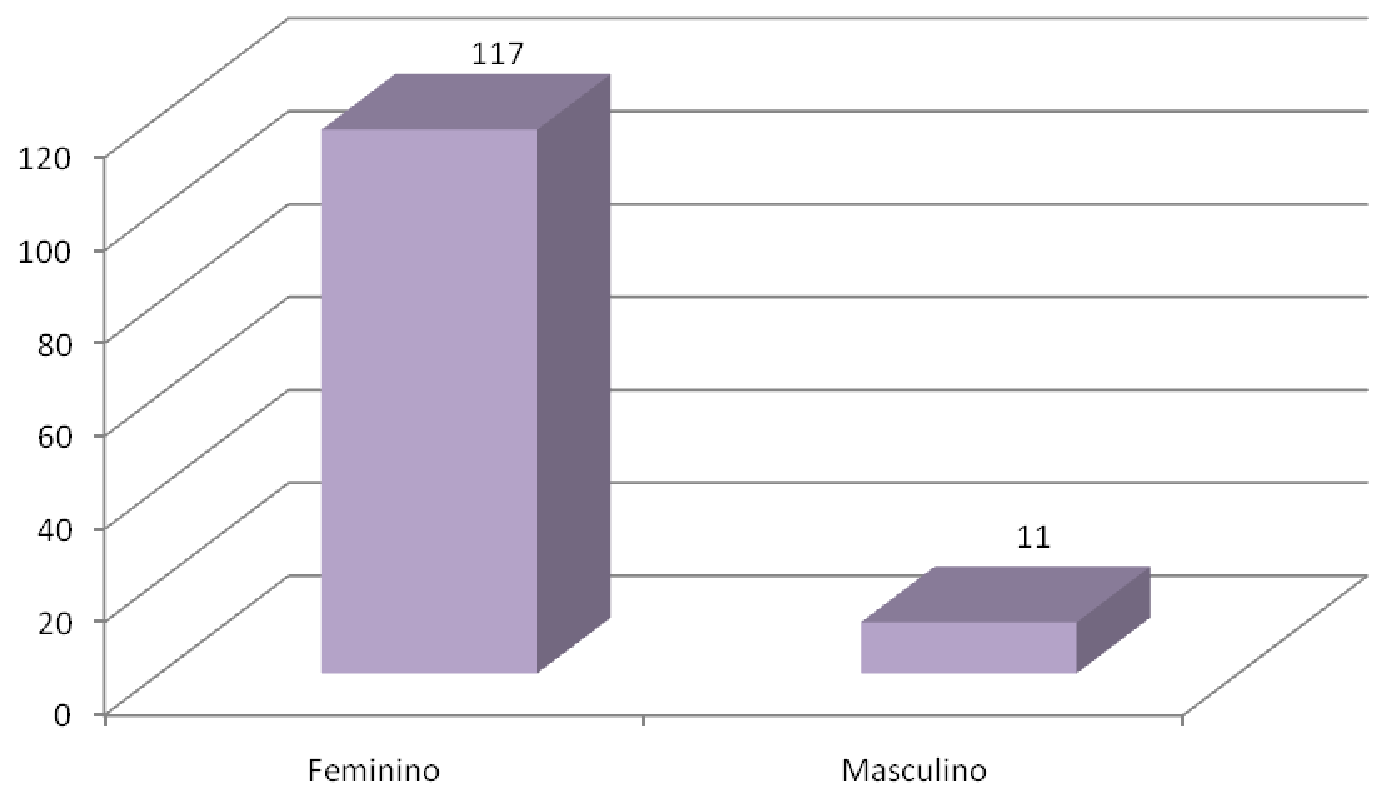

Fonte: Serviço de Graduação da Escola de Enfermagem da USP.

Observou-se uma discrepância numérica dos alunos não brancos (homens e mulheres), no período de 1947 a 2006, com predominância do gênero feminino. Tal constatação é compreensível, pois segundo Costa e Freitas (2010) a distribuição numérica dos estudantes (homens e mulheres) formados na Escola de Enfermagem da USP, nas décadas de 1950 a 1990, revelou um quantitativo de 1966. Deste contingente, apenas 36 pertenciam ao sexo masculino. Portanto, a média proporcional observada foi de apenas 1 homem para, aproximadamente 54,6 enfermeiras. 


\section{METODOLOGIA}

\subsection{REFERENCIAL METODOLÓGICO}

Por ser o presente trabalho de natureza descritiva, histórico-social e exploratória, optou-se pelo o método da História Oral de Vida.

O método da História Oral é definido por Freitas (1993) como um método de pesquisa que utiliza a técnica da entrevista e outros procedimentos articulados entre si, no registro de narrativa da experiência humana. Já para Alberti, citado por Borenstein (1998), a história oral é um método de pesquisa que privilegia a realização de entrevistas com pessoas que participaram de, ou testemunharam, acontecimentos, conjunturas, visões de mundo, como forma de se aproximar do objeto de estudo.

Meihy (2002) relata que a base da existência da história oral é o depoimento gerado. Neste sentido, pode-se dizer que três elementos constituem a condição mínima da história oral: os entrevistados, o entrevistador e a aparelhagem para gravar o depoimento. Para ele, há três modalidades de historia oral: história oral de vida, tradição oral e história oral temática.

A história oral de vida é o depoimento de um indivíduo acerca de sua experiência de vida. Para tanto, devemos dar espaço para que o faça com maior liberdade possível, podendo conduzir seu depoimento sozinho, com o mínimo de interferência do entrevistador. O que importa é a vida do narrador, a história de sua experiência pessoal e a preservação de uma narrativa natural e ampla.

A tradição oral trabalha com grandes mitos, visões de mundo, valores, 
crenças e tradições antigas de uma comunidade. Neste gênero, o sujeito da pesquisa é mais coletivo e menos individual, sendo ela utilizada em trabalhos com tribos, clãs, sociedades urbanas e industriais entre outras.

O método que melhor corresponde aos objetivos deste projeto é a História Oral Temática, pois ela se compromete com o esclarecimento ou a opinião do entrevistado sobre um evento específico, no caso, as possíveis situações de racismo vivenciadas pelos sujeitos desse estudo, em seus respectivos contextos históricos e sociais, dentro das três categorias pré-definidas.

Assim, ao escolhermos o referencial teórico da História Oral Temática, fizemo-lo por acreditar que viabilizaria a coleta de dados, desvelando-se a existência de possíveis preconceitos, direcionando as entrevistas para os objetivos propostos, pois, nos dizeres de Meihy (2002) tal método possibilita que as pessoas falem livremente, em seus respectivos contextos.

Para Borenstein (1998), o fato da existência de uma determinada história, que se quer relatar, ser relativamente contemporânea e, muitos dos personagens ainda se encontrarem no cenário da vida, torna-se possível lançar mão do instrumento da História Oral para reconstruir essa história a partir dos próprios personagens. De fato, "a história oral contribui na elaboração de uma memória mais democrática; é um instrumento de mudança capaz de colaborar na construção de uma sociedade mais justa. A História Oral possibilita novas versões da história ao dar a voz a múltiplos e diferentes narradores" (Thompson, 1992. p. 18-19).

Este tipo de projeto propicia fazer da história uma atividade mais democrática a cargo das próprias comunidades, uma vez que permite construir a história a partir das próprias palavras daqueles que a vivenciaram e que participaram de um determinado período, mediante suas referências e, também, do seu imaginário. 
Enfim, segundo Borenstein (1998), o método da história oral possibilita o registro de reminiscências das memórias individuais ou a reinterpretação do passado.

Após a coleta dos dados, utilizou-se, para a análise dos conteúdos dos discursos dos sujeitos participantes, a fim de organizar e discutir os achados, o referencial de análise proposto por Minayo (1994).

O trabalho fundamental da História da Enfermagem constitui o estudo dos cuidados através do tempo em diferentes contextos culturais (Siles, 1999). Assim, a História só pode ser concebida como uma ciência interpretativa e sujeita à análise crítica (hermenêutica aplicada). Um marco teórico pertinente pode ser o que representa a história antropológica e cultural. Desse modo, a escolha da Transculturalidade do cuidado, permitiu ao estudo profundidade em diversos fatores que incidem sobre a conformação do fenômeno, no caso, Ser Enfermeiro Negro.

Com isto, ao escolhermos a metodologia qualitativa para pesquisa, pudemos observar que, somente ela, permitiria o desvelar do fenômeno, que se deu mediante da narrativa de situações vividas. Como enfatiza Siles et al (2001), as fontes narrativas (oral, escrita e visual) nos permitem chegar ao aprofundamento do pensamento e sentimentos das pessoas de forma paralela à observação dos acontecimentos mais evidentes, tais como os comportamentos racistas.

\subsection{PERCURSO METODOLÓGICO}

Após a aprovação do estudo pelo Comitê de Ética em Pesquisa da Escola de Enfermagem da Universidade de São Paulo (CEP/EEUSP - Processo número: 780/2008) e a liberação da coleta de dados junto aos documentos da Escola de Enfermagem da USP (Processo número: 97/2009/CPq/EEUSP), iniciou-se a coleta 
de dados.

Essa coleta se deu a partir da análise das fichas de admissão dos egressos da EEUSP, buscando identificar os negros que se formaram pela escola no período de 1942 a 2006. Este processo se deu no intuito de confirmar os dados coletados em pesquisa de Iniciação Científica. Com isso, confirmou-se que são 128 os egressos negros da instituição dentro do período mencionado.

A partir do conhecimento da existência desses indivíduos, foi realizado contato telefônico com os que, por diversos motivos, não haviam participado das entrevistas durante o projeto de Iniciação Científica. As entrevistas realizadas foram pautadas na técnica de coleta de dados da História Oral, de enfermeiros negros egressos da EEUSP, que residiam no Município de São Paulo, ou na região metropolitana, e que possuíam, até a data da entrevista, Registro Profissional junto ao Conselho Regional de Enfermagem (COREN) do Estado de São Paulo. Portanto, foram realizadas, ao todo, 14 entrevistas, não havendo a possibilidade de ampliar o número devido à recusa dos sujeitos.

Dentre os motivos apresentados para a não participação no projeto, os principais mencionados foram: falta de disponibilidade de tempo para a entrevista e a falta de interesse em participar do estudo. Vale salientar que dois contatados afirmaram não poderem participar por não se declararem negros.

Por se tratar de uma pesquisa de abordagem qualitativa, não foi delimitado, previamente, o número de participantes do estudo. As dificuldades encontradas, mencionadas no parágrafo anterior, para a coleta de dados limitou o número de entrevistas que poderiam ser realizadas. Entretanto, os discursos dos participantes possibilitaram o desvelamento do fenômeno investigado. 
No tocante, ainda, ao percurso metodológico, cabe ressaltar que, antes da realização de cada entrevista, os sujeitos foram informados sobre os objetivos da pesquisa e assinaram um termo de consentimento livre e esclarecido. As entrevistas foram realizadas no local de escolha dos sujeitos e foram pautadas em quatro questões norteadoras, que permitiram aos sujeitos discorrerem livremente sobre o assunto, enriquecendo assim, o conteúdo das entrevistas. A duração das entrevistas, que variaram de uma a quatro horas, foi determinada pelos próprios entrevistados conforme revelavam seus pontos de vista sobre o tema.

Cabe ressaltar que, em algumas entrevistas, utilizaram-se outras perguntas além das norteadoras pré-definidas procurando, com elas, esclarecer dúvidas, estimular a exposição contínua e aprofundar o assunto buscando maiores detalhes. Essa manobra foi bem aceita por parte dos entrevistados gerando, assim, maior riqueza de discurso. Além do discurso, observou-se também a comunicação não verbal dos entrevistados, a fim de enriquecer a análise.

Para manter o sigilo, optou-se por identificar os colaboradores através de uma sequência numérica arábica, porém, as transcrições não foram numeradas de acordo com a ordem crescente das entrevistas a fim de se evitar qualquer possibilidade de se identificar os colaboradores. Entretanto, as transcriações respeitaram o estilo de cada colaborar, valendo-se de expressões idiomáticas e mantendo os vícios de linguagem para que se pudessem observar seus contextos pessoais.

Após a transcrição das 14 entrevistas realizadas, as falas foram agrupadas em três categorias definidas inicialmente sobre o preconceito: pelo fato de serem negros ao escolherem a profissão; durante a trajetória acadêmica na EEUSP e no ingresso profissional. Como alguns entrevistados não haviam ingressado no mercado de trabalho, a terceira categoria foi ampliada para se discutir as preocupações dos sujeitos em relação ao papel que sua etnia desempenharia no processo. 


\section{REFERENCIAL TEÓRICO}

\subsection{A TRANSCULTURALIDADE DO CUIDADO}

É imprescindível salientar que a enfermagem, em todas as suas dimensões, é pautada na busca pelo cuidado com o outro. Sendo ela exercida de forma leiga ou profissional, a enfermagem tem como principal característica a preocupação com o bem estar do outro, estando esse indivíduo em uma situação de enfermidade ou não.

Entretanto, como afirmado anteriormente, a busca pela ciência e pela profissionalização da prática de enfermagem fez com que muitos estudiosos da área da saúde, e também dos cuidadores em si, buscassem teorias científicas para embasar suas práticas e suas formas de pensar. Essa busca gerou o que chamamos hoje de Teorias de Enfermagem.

Florence Nightingale foi, sem dúvida, uma das primeiras teoristas da enfermagem moderna, pois utilizando a observação em campo, definiu os procedimentos que deveriam ser adotados durante a Guerra da Criméia para que o cuidado com os soldados se desse de maneira mais efetiva, reduzindo, assim, a taxa de mortalidade para $2 \%$.

Essas observações aplicadas geraram um livro que, até hoje, é um dos pilares da enfermagem. Notas sobre Enfermagem, de 1859, é, até os dias atuais, o livro de referência sobre os princípios fundamentais da enfermagem (Oguisso, 2007).

A brasileira, e teorista da enfermagem, Wanda de Aguiar Horta (1979), traz em seus estudos uma discussão sobre a importância de a enfermagem se 
comprometer não somente com o cuidar, mas também com o "pensar a realidade", para que, dessa forma, o enfermeiro possa exercer um cuidado mais efetivo e mais dinâmico.

Dentro de sua teoria, Horta (1979) nos traz que é possível classificar a enfermagem em três dimensões: a do Ser-Enfermeiro, a do Ser-Cliente e a do SerEnfermagem. Dessa forma, ela afirma que Ser-Enfermeiro é ser um ser humano comum que se engaja no compromisso de conhecer, estudar e obter, da sociedade, o direito de cuidar de pessoas, enquanto que o Ser-Cliente são todos aqueles que necessitam de cuidado em alguma, ou em qualquer, fase do processo saúde-doença, durante seu ciclo de vida. Entretanto, Ser-Enfermagem é mais complexo e abstrato, surgindo apenas quando os dois primeiros seres mencionados interagem. Esse último tem como objetivo assistir as necessidades humanas básicas dos indivíduos.

Então, para que o Ser-Enfermeiro cuide do Ser-Cliente de forma adequada, ele precisa conhecer o sujeito que está sendo cuidado em todas as suas dimensões, ou seja, ele precisa exercer um cuidado que abranja as dimensões biopsico-socio-culturais de seu cliente.

Dessa maneira, Wanda Horta explica que para exercer a enfermagem é necessário que se faça o chamado Processo de Enfermagem, que é formado por duas questões distintas, mas que, necessariamente devem ser aplicadas juntas, são elas: a assistência de enfermagem e o cuidado de enfermagem. 
FIGURA 2 - O Processo de Enfermagem, segundo Wanda Horta

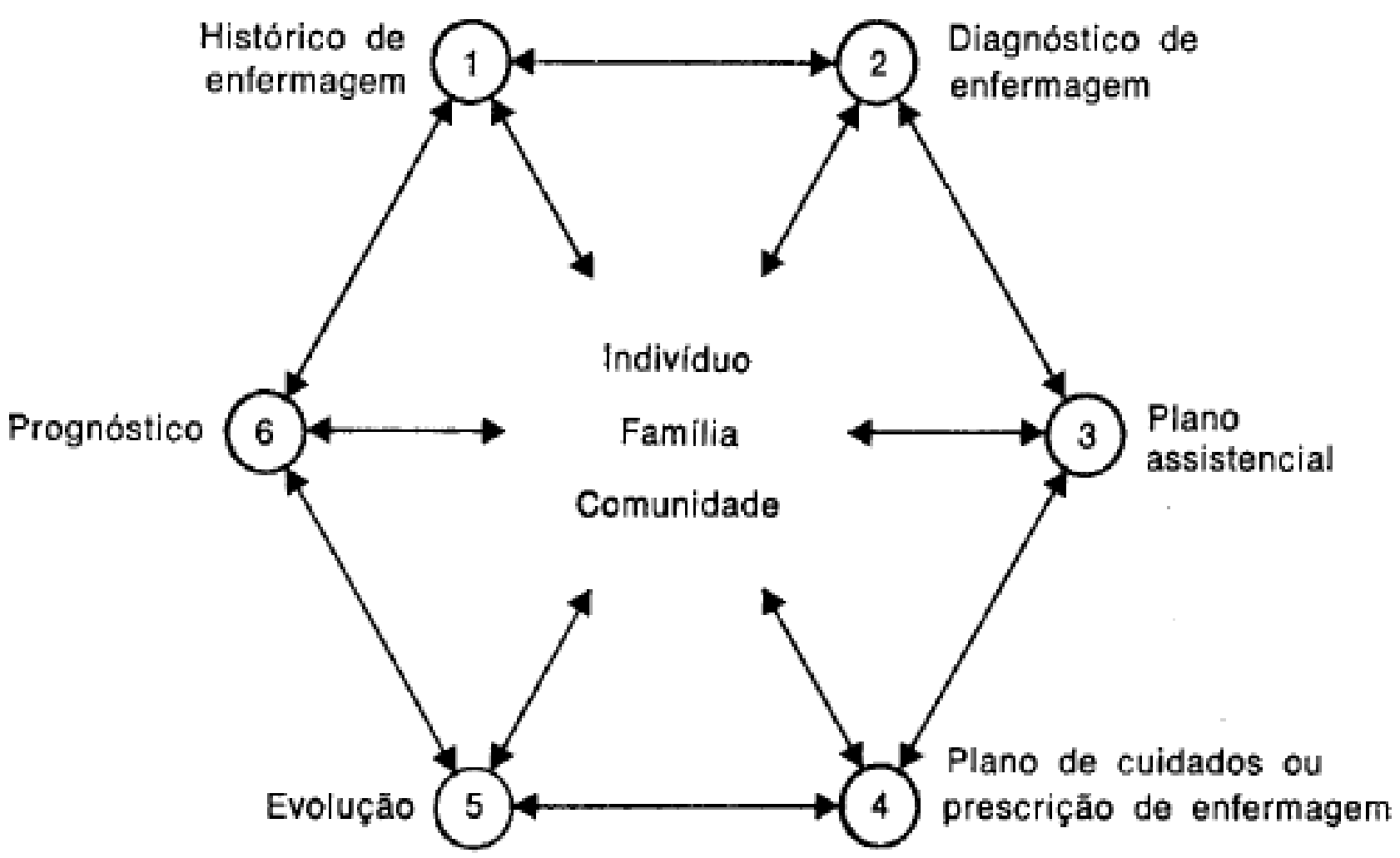

Fonte: HORTA, W.A. Processos de Enfermagem. São Paulo: EPU, 1979. p. 35.

Assim, a assistência de enfermagem diz respeito ao conjunto de ações, cuidados e medidas que visam atender as necessidades básicas de cada indivíduo. Enquanto o cuidado de enfermagem é a ação deliberada, o planejamento da assistência, que vai partir da percepção de cada enfermeiro e da análise e observação que cada um faz do comportamento, condição e situação do ser humano que está sendo cuidado. (Horta, 1979) 
Sendo o cuidado de enfermagem algo inerente a percepção de cada indivíduo que o exerce, pode-se concluir que ele se molda de acordo com a teoria onde é pautado. Ele pode, assim, acontecer de forma mecânica, ao se pautar apenas nos aspectos técnicos e clínicos, ou de forma mais abrangente, levando-se em consideração a cultura, a inserção social e a percepção do próprio indivíduo sobre aquilo que está acontecendo.

Para Marie-Françoise Collière (1999), pautar o cuidado de enfermagem apenas nas técnicas permitiu que a enfermagem se consolidasse como profissão ao imitar aquilo que servia como valor para medicina, que era curar as doenças. Assim, também, a enfermagem se distancia dos problemas dos pacientes e transforma a doença no objeto do cuidado.

Dessa forma, a enfermagem não é capaz de enxergar o indivíduo, cuidando apenas do biológico e negando as outras dimensões que nos fazem sereshumanos. O trabalho de enfermagem, nessa perspectiva, se torna algo mecânico e frio, tornando-se uma simples realização de tarefas definidas previamente pelo profissional médico.

Ao valorizar o indivíduo que está sendo cuidado em todas as suas dimensões, a enfermagem gera oportunidades de abranger o cuidado também na promoção, prevenção e readaptação do indivíduo, que vão além do âmbito curativo. Assim, Horta (1979) afirma que:

\footnotetext{
“A prática de enfermagem encontra a sua razão de ser na pessoa tratada. É o doente que é o referente, o ponto de partida e de chegada dos cuidados. Não é já considerado como um objeto portador da doença $\mathrm{x}, \mathrm{y}, \mathrm{z}$, mas constitui, realmente, a finalidade dos cuidados que não adquirem sentido senão a partir dele, daquilo que é, do que representa no seio do seu ambiente social. Já não é objeto dos cuidados, mas torna-se objeto de cuidados, quer dizer que os cuidados não têm sentido senão em relação com a sua realidade, com a maneira como vive - entre outras coisas - como vive sua doença.”(p. 151)
} 
Dessa forma, a Teoria Transcultural de Madeleine Leininger, lançada em meados dos anos de 1950, traz que o cuidado torna a essência da enfermagem, como uma, poderosa e dinâmica, força para entender a totalidade do comportamento humano na saúde e na doença no mundo todo. Contudo, é preciso salientar que, nessa teoria, temos dois tipos de "cuidado". O primeiro, chamado "cuidado humano" (no inglês, caring) é visto como ações, atitudes e práticas para assistir ou ajudar outros em direção a cura e o bem-estar. Contudo, o cuidado (no inglês, care) é definido como atividades de assistência e apoio, na ajuda ou facilitação do outro com necessidades evidentes ou antecipadas, a fim de melhorar ou aperfeiçoar a condição humana ou o modo de vida. (Leininger, McFarland, 2006).

Para Leininger, a teoria transcultural da diversidade e universalidade do cuidado é capaz de predizer e explicar os padrões de cuidado humano das diversas culturas, bem como possibilitar a identificação de valores, crenças e práticas populares dos profissionais e da enfermagem; e que, por meio deste conhecimento, as decisões e as ações de enfermagem podem tornar-se congruentes e benéficas para aqueles que são assistidos. (Gualda, Hoga, 1992).

Dessa forma, Gualda e Hoga (1992) esclarecem alguns dos principais pressupostos da Teoria Transcultural:

- A enfermagem é um fenômeno essencialmente transcultural que envolve o contexto e o processo de ajuda a indivíduos de diferentes orientações culturais ou de estilos de vida específicos dentro de determinada cultura.

- O cuidado é um fenômeno universal, e as formas de manifestação variam dentre os diversos grupos na relação tempo-espaço, alterando, na forma, a busca de seus atributos. 
- O cuidado, as manifestações, os processos, os valores e as crenças de enfermagem transcultural precisam ser explicados de maneira sistemática e científica com bases humanísticas.

- O cuidado de enfermagem terapêutico ou eficaz é, na maioria das vezes, culturalmente determinado e embasado e pode ser culturalmente validado.

- As culturas têm seu modo peculiar do comportamento relativo ao cuidado, que é geralmente conhecido pelos integrantes da própria cultura, mas frequentemente desconhecido por enfermeiras com bagagem cultural diferente.

- A essência da enfermagem é o cuidado; a essência da enfermagem transcultural é o cuidado a indivíduos de diversas heranças culturais.

- Os processos, as funções e atividades de enfermagem transcultural variam de acordo com a estrutura social e o sistema cultural e, em relação à sua história cultural, com seus contatos e sua aculturação.

- As formas simbólicas do cuidado de enfermagem, e seu respectivo significado estão intimamente relacionados às normas e crenças culturais que demandam estudo sistemático e representam modalidades importantes na compreensão e ajuda a determinados grupos. 
Para melhor explicar a aplicação da teoria, Leininger propõe o "Sunrise Enabler" (Modelo do Sol Nascente), que guia os estudos da compreensão e múltiplas influências na análise do significado do cuidado para as diversas culturas. O modelo operacionaliza a teoria e orienta o estudo da diversidade e universalidade do ato de cuidar. (Gualda, Hoga, 1992).

\section{FIGURA 3 - The Sunrise Enabler, por Madeleine Leininger.}

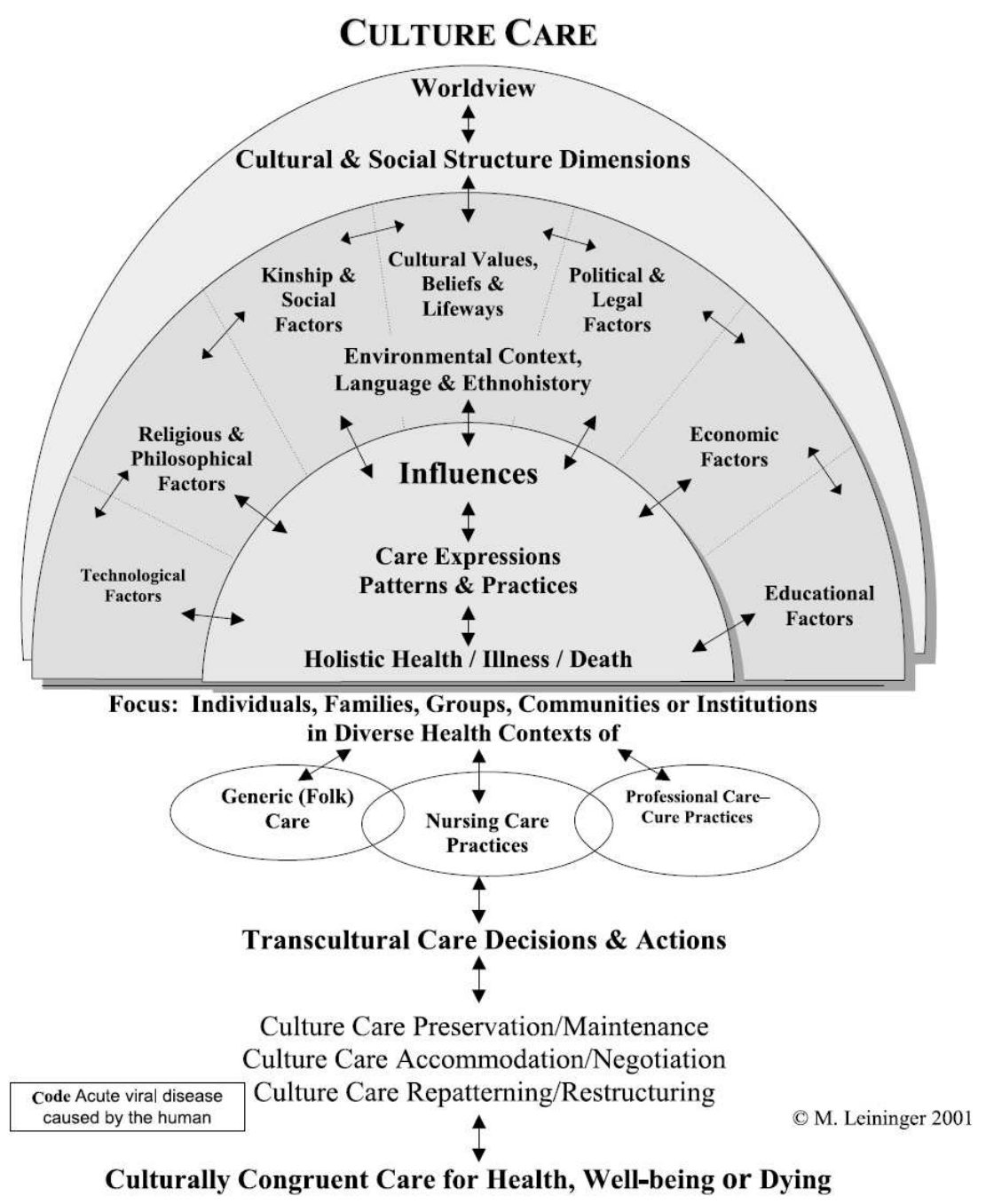

Fonte: LEININGER, M.M. MCFARLAND, M.R. Culture care diversity and universality: a worldwide nursing theory. 2nd ed. Jones and Bartlett Publishers, Inc. - 2006. p.25.

$\mathrm{Na}$ parte superior temos os componentes interdependentes da estrutura social e que influenciam o cuidado e a saúde por meio da linguagem do contexto 
ambiental. Esses fatores vão influenciar o sistema de saúde, que é composto pelo sistema popular, profissional e o de enfermagem, que se encontra na parte inferior do modelo. Juntando as duas porções temos um sol completo que corresponde ao universo que precisa ser explorado pelos enfermeiros para que se possa conhecer o cuidado humano e sua relação com a saúde dos indivíduos. (Gualda, Hoga, 1992).

Há ainda os três níveis de análise desse cuidado: o macro, o médio e o micro, que referem à abrangência do estudo do cuidado. Esses níveis são classificados de I a IV, sendo o primeiro o de maior abstração e os outros sucessivamente.

O nível I engloba o sistema social e a percepção de mundo sob três perspectivas: micro - estudos de indivíduos dentro de uma determinada cultura; média - estudos de uma cultura específica; e macro - estudos de várias culturas.

O nível II estuda o cuidado e a saúde no contexto de um sistema de saúde, no qual estão incluídos os indivíduos, suas famílias e culturas, buscando seus significados.

O nível III estuda os sistemas profissional e popular, buscando características e aspectos específicos de cada um, com a finalidade de serem determinadas as áreas de semelhança e diferença.

O último nível, IV, é utilizado para o desenvolvimento de um tipo de cuidado de enfermagem congruente com as culturas e valorizado por estas. (Leininger 1985, 2002; Leininger, Mcfarland, 2006; Gualda, Hoga, 1992)

Quando citam os objetivos propostos por Leininger, Gualda e Hoga (1992), afirmam: 
“(...) O objetivo da enfermagem transcultural vai além da apreciação de culturas diferentes, mas de tornar o conhecimento e a prática profissional culturalmente embasada, conceituada, planejada e operacionalizada. (...) Se aqueles que praticam a enfermagem não considerarem os aspectos culturais da necessidade humana, suas ações poderão ser ineficazes, e trazer conseqüências desfavoráveis para os assistidos”. (p. 76-77)

A Teoria do Cuidado Transcultural, enfatiza que há diversidades no cuidado humano, com características que são identificáveis e que podem explicar e justificar a necessidade do cuidado transcultural de enfermagem, de forma que este se ajuste às crenças, valores e modos das culturas, para que um cuidado benéfico e significativo possa ser oferecido.

Com isto, parte-se do pressuposto que o Ser Enfermeiro Negro na perspectiva da Transculturalidade constitui elemento importante para a compreensão do cuidado transcultural, considerando que a escolha profissional desses enfermeiros, bem como, o modo de vida, a formação e atuação desses profissionais são determinantes para a análise mais ampla da cultura da população alvo da presente investigação.

A Teoria da Transculturalidade vem sendo utilizada ao longo dos anos como referencial teórico e/ou metodológico de estudos conduzidos em enfermagem em diversos países. No Brasil, a teoria tem se mostrado um importante instrumento para se conhecer a clientela que a enfermagem precisa assistir. Entretanto, tendo em vista a aplicação interdisciplinar da referida teoria, evidencia-se sua aplicação na administração, educação, pesquisa e saúde mental (Oriá, Ximenes, Alves, 2010).

Optou-se por esse referencial teórico porque a diversidade cultural desse coletivo da enfermagem revelou nuances culturais importantes e possibilitou conhecer mais profundamente o fenômeno da presente investigação e o universo cultural desses sujeitos, que integram a diversidade cultural dos enfermeiros, mas 
especificamente dos enfermeiros negros egressos da Escola de Enfermagem da Universidade de São Paulo (EEUSP).

Sendo assim, analisar os discursos sobre a discriminação racial encontrados nas entrevistas do presente estudo sobre a ótica da Teoria Transcultural nos permite pensar a enfermagem num âmbito que vai além da assistência hospitalar. Permite também, formar profissionais mais observadores das dinâmicas do racismo e que, em sua vida profissional, poderão aplicar teorias como a citada acima para caracterizar sua prática, permitindo que a assistência de enfermagem se configure cada vez mais como uma assistência científica que busca a humanização de suas ações em todos os âmbitos. 


\section{A CONFIGURAÇÃO DO RACISMO}

Com uma história que remonta desde o início das descobertas do século $\mathrm{XV}$ que ampliam os limites das civilizações ocidentais, o racismo vem sendo discutido em diversos âmbitos da ciência.

Costuma-se dizer que o início da classificação humana em "raças" se dá no século XVIII, denominado século das Luzes, onde o homem começava a buscar outras razões para explicar os fenômenos que o cercavam sem se basear nas explicações da Igreja. Assim, para saber quem eram os outros recém-descobertos, os estudiosos usaram os conceitos de raça existentes nas ciências naturais e nomearam esses "outros", que se integraram à antiga humanidade como raças diferentes. (Brandão, 2004)

A partir daí, a cor da pele se torna o divisor da espécie humana em três "raças" que ainda se mantêm no imaginário coletivo: a raça branca, a negra e a amarela.

A partir dessa classificação e do desenvolvimento da medicina, passou-se a não somente classificar os indivíduos dentro dos critérios de raça, mas iniciou-se o processo de valorá-las dentro de uma escala, relacionando assim o biológico com qualidades morais, psicológicas, culturais e intelectuais. Dessa forma, a classificação passou a denominar que os indivíduos de "raça branca" eram superiores aos de outras raças em função das suas características físicas, o que, consequentemente, o tornava mais apto a dominar as outras, principalmente a negra, que foi considerada a mais emocional, a menos honesta e a menos inteligente. (Brandão, 2004)

Essa idéia se dissemina no mundo e, consequentemente, no Brasil. Dessa 
forma, mesmo após a abolição da escravidão, o negro é visto como inferior e perigoso, dando espaço para que ele seja julgado por suas características físicas e tenha menos direitos perante a lei.

Esse fato é bem explicitado por Souza Campos $(2008)^{2}$ no texto que

segue:

\begin{abstract}
"Como destacado, o início do século XX evoca o surgimento de um sistema político fundado na cidadania. A posse de negros havia acabado legalmente, mas as representações da escravidão ainda projetavam imagens que depreciavam os negros. Ao mesmo tempo, o período inaugura a formação profissional da enfermagem brasileira com a adoção do modelo oficial de ensino da enfermagem Brasil, como uma das realizações da Reforma Carlos Chagas, que reorganiza a estrutura sanitária federal nos anos 1920. O período permite entender as origens da institucionalização do controle social em duas grandes cidades, Rio de Janeiro e São Paulo. Especificamente, permite problematizar representações impostas às pessoas pobres e negras, cujos significados evocavam imagens sociais desprestigiadas, que os apresentavam como degenerados, pertencentes a um tipo humano inferior, primitivo, ainda que imageticamente. As representações sugeridas, presentes em discursos inaugurais da República, geraram um universo estereotipado, polissêmico e acentuado por uma legitimidade totalizadora, que pretendia controlar a população de negros, assim como suas interferências na vida social mais ampla. Produzidos e disseminados por intelectuais que assumiam diferentes postos na administração pública, dirigindo instituições de controle social, tais discursos vinculavam comportamentos à "compleição física", classificando tipos humanos considerados, nessa medida, como inferiores, débeis, comprometidos geneticamente, cujas "taras primitivas" os conduziam inevitavelmente à criminalidade e à devassidão." (p. 16)
\end{abstract}

Essa "compilação física" a que se refere Souza Campos surge antes do Estado Novo (1930-1945), onde se identificavam os criminosos por traços característicos, antropometria, o que permitia reconhecer um criminoso antes mesmo que ele pudesse cometer qualquer ato do qual merecesse ser julgado.

\footnotetext{
${ }^{2}$ Souza Campos, PF. A Escola de Enfermagem da Universidade de São Paulo e a Formação da Identidade Profissional Brasileira. Relatório Parcial FAPESP. São Paulo: Departamento de Orientação Profissional da Escola de Enfermagem da USP; 2008.
} 


\section{FIGURA 4 - Representação da Medicina Antropométrica}

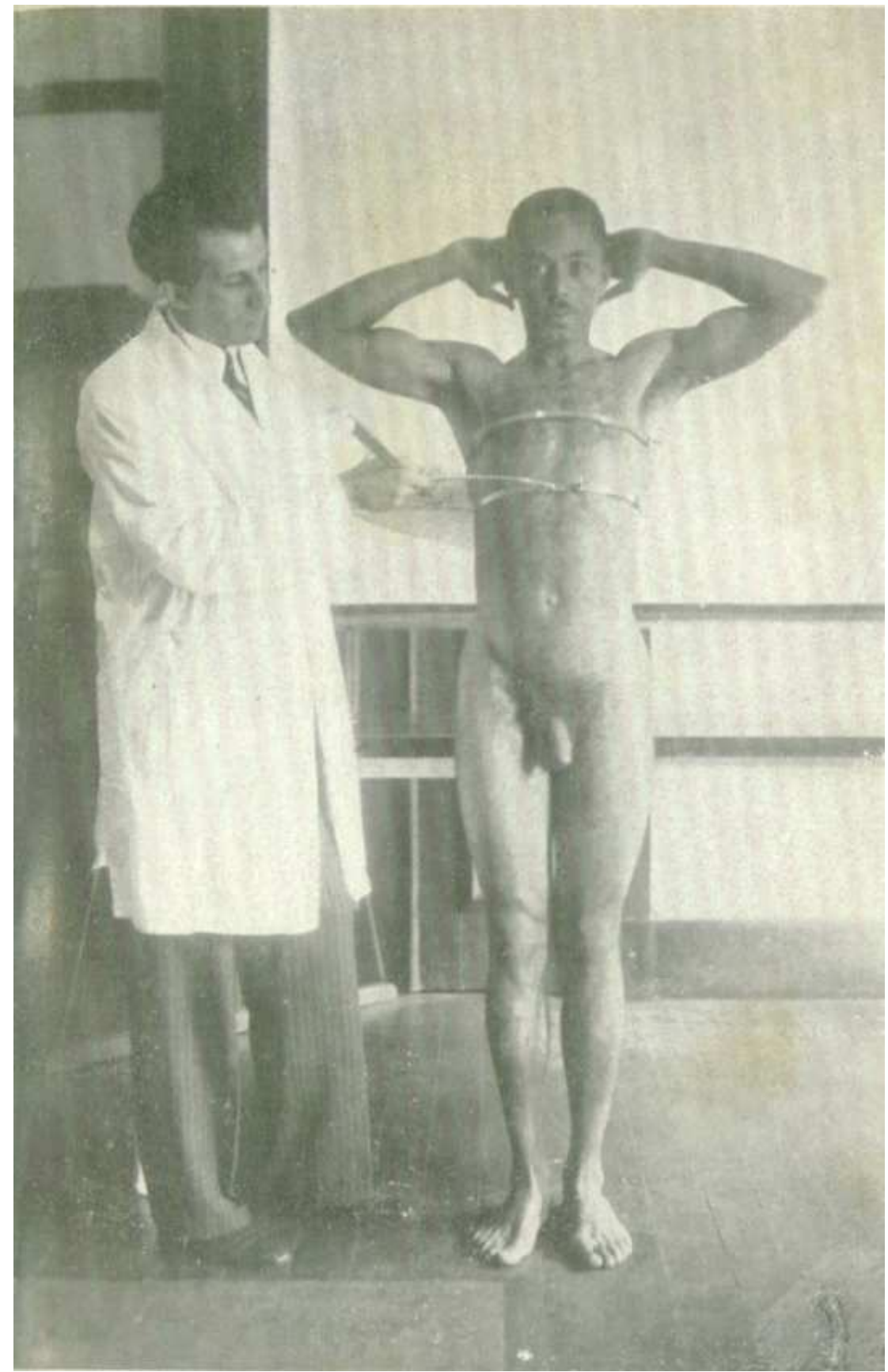

Fonte: Acervo da Biblioteca do Instituto Oscar Freire, de Medicina Legal e Criminología, da Faculdade de Medicina, da Universidade de São Paulo. 
Dessa forma, fica claro que o fenótipo é um importante fator para a instauração e a manutenção do racismo, pois os pares se reconhecem e passam a discriminar e julgar aqueles que apresentam características físicas distintas.

Para Albert Memmi (1993), “o racismo não é uma teoria científica, mas um conjunto de opiniões, ainda por cima pouco coerentes (...). É a valorização, generalizada e definitiva, de diferenças biológicas, reais ou imaginárias, em proveito do acusador e em detrimento da sua vítima, a fim de justificar uma agressão" (p. 109).

Assim, pode-se dizer que o racista não identifica os seres somente pelos traços físicos, mas também por traços culturais, sociais e linguísticos que ele considera naturalmente inferiores aos do grupo ao qual ele pertence. Dessa maneira, ele considera as características morais de um grupo como conseqüência direta de suas características biológicas. (Brandão, 2004)

Entretanto, a idéia de raça começa a ser desmistificada a partir dos anos 70, quando as ciências biológicas começam a modificar os então conhecidos conceitos de raça. É nesse período, porém, que o uso do termo "racismo" passa a uma dimensão mais ampla, usando-o para definir formas variadas de preconceito, como o contra mulheres, homossexuais, pobres e etc. Nesses casos, o uso do termo qualifica como "racismo" qualquer atitude de rejeição ou injustiça social. (Brandão, 2004)

Dessa forma, acredita-se que o racismo hoje é construído com base em diferenças identitárias, que vão muito além das diferenças físicas dos indivíduos, que gera um paradoxo, fazendo com que o discriminador e o discriminado, possam usar as mesmas definições e argumentos para se defender e atacar o outro. O racismo se torna, assim, algo sutil, pouco palpável e implícito, dificultando a sua identificação. 
No Brasil essa faceta do racismo se encontra muito presente. Criou-se, ao longo do século $\mathrm{XX}$, uma imagem de que esse seria um país isento de preconceito racial. Isso se deu por causa da mestiçagem encontrada no povo brasileiro, que remonta de sua colonização pelos Portugueses e do histórico de escravidão do negro africano trazido para trabalhar nas lavouras. Do mesmo modo o preconceito de cor, ainda que pudesse ocorrer em alguns casos, seria atenuado por uma série de fatores de corte subjetivo e afetivo, ampliando as possibilidades de convívio entre as diferentes cores/etnias fazendo com que, em nosso país, tenha sido gerada uma democracia racial (Paixão, 2003).

Dessa forma, passa-se a acreditar que no Brasil o racismo não se mantém porque há uma dificuldade em se separar as "raças", já que a mestiçagem é uma das características definidoras do povo brasileiro. Entretanto, Munanga (2004) aponta que a mestiçagem no Brasil se deu a partir do "ideal do branqueamento", que buscava embranquecer a sociedade, desvalorizando assim a raça negra. Essa ideologia reforça o esforço para homogeneizar a sociedade e estimular que o negro assimile a cultura do branco, considerada a cultura superior. Ele afirma ainda que:

\footnotetext{
“(...) A mistura das raças é a condição 'sine qua non' do progresso, do estado selvagem ao estado da cultura. Para entrar na história como criadora de um grande Estado, uma raça deve ter não apenas energia e inspiração, mas também capacidade para vencer essa forte repulsão universal a misturar seu sangue com o sangue de uma outra raça” (p. 44)
}

Assim, pode se concluir que a mestiçagem de um povo e a aproximação de suas características físicas, não elimina o racismo das raízes da sociedade. A condição para a existência do racismo ultrapassa, aí, a diferença da cor entre os indivíduos, tornando assim uma ideologia e não somente um preconceito.

Dessa forma, resgatamos uma colocação de Memmi (1993) que diz que: "a acusação racista tanto se apóia sobre uma diferença biológica como sobre uma diferença cultural. (...) para generalizar em seguida ao conjunto da personalidade, da 
vida e do grupo acusado." (p. 120).

Cabe salientar aqui que apontar as diferenças entre os grupos, ou indivíduos, não caracteriza uma atitude racista. Esse ato é uma mera comparação, uma necessidade para que se estude e se caracterize as diferenças. Contudo, essa diferença ganha uma significação particular num contexto racista, a partir dessa diferença, o racista procura argumentar ou criar uma exclusão do indivíduo diferente do meio social. Assim, Memmi (1993) afirma que "a utilização da diferença é necessária no procedimento racista: mas não é a diferença que suscita sempre o racismo, é o racismo que utiliza a diferença”. (p. 121).

Neste ponto, cabe reiterar que a faceta de "igualdade racial" criada no Brasil gera um racismo mascarado. Para Santos (2004) a dinâmica de discriminação, se sustenta pelo fato de que, na sociedade brasileira, o racismo opera gerando seres que não podem reconhecer. O discriminador não reconhece que discrimina e o discriminado não percebe a discriminação. Dessa maneira, ele não reconhece como auxilia na manutenção das estruturas e dos discursos de discriminação.

Desse modo, no Brasil, o racismo gera seres defensivos que insistem (ou não podem) admitir o racismo onde ele ocorre e da forma como ocorre. Assim, o discriminado não é capaz de se defender e o discriminador continua a propagar o racismo, muitas vezes, sem perceber sua presença em seus discursos.

A essa cordialidade brasileira, acerca do racismo, Santos (2004) diz que brancos e negros ao utilizarem as máscaras do racismo, estão fascinados por esse estranho poder e, nesse sentido, se tornam indiferenciados. Assim, a maior força do racismo é a de fazer com que todos sejam submissos à forma de ser e de pensar racista, em que todos desejam ser branco. A brancura aqui entendida não somente como "cor" de pele, mas como símbolo hegemônico da cultura. 
Como a cultura representa um conjunto de valores que são assumidos e expressos dentro de um determinado país como signos de sua nacionalidade, ela vai ser semelhante à ideia da existência de valores hegemônicos (ou nacionais) que se sobrepõem a outros que não representariam, de acordo com a lógica dominante, a cultura da nação. Dessa forma, por mais que existam diferentes culturas dentro de um mesmo país, como é o caso do Brasil, utiliza-se apenas uma para representar a nação como um todo.

Sendo assim, por maiores que sejam as diferenças nos contextos dos indivíduos, a convivência social e os grupos ao qual pertencemos influenciam nossas ações, refletindo, assim o quão propensos estamos a aceitar novos valores a fim de nós mantermos e nos identificarmos com o nosso grupo social. Santos (2004) defende que o negro, ao usar a máscara do racismo, não pode ver nem a si nem ao outro. Vive em um mundo de mascarados e são somente as máscaras que ele pode enxergar. E como os valores racistas em relação aos negros são os da negação, da criação de estereótipos, da violência física e psíquica, o negro mascarado perpetua a negação, a violência, a estereotipia contra si e contra os outros.

É assim que se perpetua a idéia do "ideal do branqueamento", pois ao utilizar a máscara do racismo, como proposto por Santos (2004), o negro se torna "branco" não fisicamente, mas a partir da partilha dos valores e da cultura do branco e de todas as formas de identificação.

Nessa ótica, não é incomum encontramos pessoas de etnia negra que não se identificam como tal, como foi o caso de dois dos contatos feitos para coleta de entrevistas do presente estudo. Os indivíduos, inicialmente identificados por nós em suas fichas de admissão (o primeiro identificado pela foto e o segundo identificado pela certidão de nascimento) se negaram a participar do estudo por não se declararem negos. 


\section{PERFIS DOS COLABORADORES}

Para que possamos compreender melhor quem são os participantes dessa pesquisa, optamos por caracterizá-los de acordo com os pontos mais marcantes de cada entrevista.

\subsection{Colaborador 1}

"O preconceito existe sim, isto é fato. E é notado ou praticado em maior ou menor escala dependendo de diversos fatores, como região, classe social, locais de convivência, programas na TV."

Para o primeiro colaborador, formado em 2004, o preconceito existe em diversos locais, inclusive na universidade. Após afirmar ter sofrido preconceito racial, principalmente em sua infância, o colaborador deixou claro que acredita que hoje não é mais vítima do preconceito por frequentar lugares "onde a raça negra é predominante". Entretanto, em sua fala, deixa claro acreditar que não conseguiu se inserir no mercado de trabalho, até o momento da entrevista, devido ao preconceito racial. Segundo ele, na enfermagem, o preconceito em relação ao gênero é algo premente na universidade e que, durante sua graduação, não foi vítima do racismo, apesar de relatar uma experiência racista entre ele e uma colega. Ressalta ainda que, nos serviços de saúde, é vítima de preconceito racial e de gênero, em especial pelos usuários. O colaborador afirmou também que as formas de se combater o racismo são amplamente discutidas, contudo, ainda precisam ser efetivadas. 


\subsection{Colaboradora 2}

"O preconceito vem de todas as partes da comunidade EEUSP. Se você tem a pele escura já começam a te chamar de pretinha, se você tem carro ou não tem, a forma de se vestir, as amizades que se fazem. O preconceito esta em todas as partes, vai do olhar de cada um."

A segunda colaboradora, especialista em Saúde Pública e Saúde da Família, disse se declarar negra por acreditar que essa é a forma mais correta de se referir a sua etnia. Relatou ter escolhido a enfermagem por vontade de ajudar ao próximo e que, apesar de ter sofrido preconceito pela escolha de sua profissão por parte de algumas pessoas, sempre contou com o apoio da família. Entrou na EEUSP pelo vestibular universal e disse ser a favor das cotas para negros nas universidades. Apresentou diversos relatos de situações de preconceito por ela sofridas, tanto dentro da universidade como durante o exercício profissional, descrevendo, principalmente, sua experiência no Programa de Saúde da Família. Afirmou também, acreditar que uma forma de se combater o preconceito é dando maiores oportunidades para os negros, principalmente oportunidades de crescer financeiramente. 


\subsection{Colaborador 3}

"Quando eu entrei, eu era considerado como uma coisa exótica, por ser diferente, de outro país, entendeu? Tem a curiosidade de saber como é que é lá de onde eu vim. Por se Africano, tem então essa questão, e dentro desta questão de ser africano, tem então a questão do negro, da negritude, então o negro africano ele é tratado um pouco diferenciado do negro brasileiro por um simples motivo, ele é um bicho exótico, ele é uma coisa diferente, ele é diferente daquele negro nascido aqui."

O terceiro colaborador, nascido em Guiné-Bissau, chegou ao Brasil no ano de 1989 para cursar teologia, e depois acabou ingressando na enfermagem por querer seguir uma carreira docente em alguma matéria básica, como Fisiologia Médica, e por acreditar que esse seria o caminho mais fácil para alguém com dificuldades financeiras para custear um curso mais longo. No período da entrevista relatou trabalhar com Saúde Pública, na área de Saúde da Família, e ter vontade de terminar a pós-graduação que havia iniciado, porém, não havia concluído. Relatou, em seu discurso, que o preconceito no Brasil é velado e, muitas vezes, não interpretado como reais atitudes racistas. Em suas falas, apresenta as dificuldades de ser negro e africano no Brasil, além de relatar diversas vivências racistas, tanto no período de sua formação, quanto em sua atuação profissional. 


\subsection{Colaboradora 4}

"O que eu sei é que existem pessoas que não gostam e não aceitam as pessoas negras, acredito que por um problema exclusivo delas. Eu não pego isso como se fosse um problema meu."

A quarta colaboradora, especialista em UTI e licenciada em Enfermagem, relatou ter escolhido a enfermagem porque tinha vontade de cuidar das pessoas. Ingressou na universidade pelo vestibular universal e admitiu que, apesar da grande diferença em números entre negros e brancos, nunca sentiu preconceito racial dentro da EEUSP, entretanto, relatou experiências em sua atuação profissional tanto por parte de outros profissionais como por parte dos usuários do serviço. Afirmou ainda, em seu discurso, que a melhor forma de se combater o racismo é quando o negro se insere no mercado de trabalho e conquista posições sociais, pois acredita que o preconceito racial está muito ligado a condição financeira dos negros. Ressaltou ainda que o preconceito no Brasil se apresenta de forma velada e que os recém-formados não devem temer se colocarem no mercado de trabalho. 


\subsection{Colaboradora 5}

"Eu nunca me disse branca, nunca me considerei, sei lá, a nível de preconceito, porque assim, às vezes as pessoas vêm, na minha família mesmo tem gente que já teve problema, tem problema e é uma coisa concreta, das pessoas falarem mesmo no sentido deles perceberem, sabe? Mas eu nunca. Nem assim no local onde eu trabalhei, pode ser que tenha, acredito que possa ter acontecido, mas foi um a coisa sutil. E eu como tava assim, eu me sentia bem fazendo o que eu estava fazendo, sabendo que eu estava fazendo certo, então eu não tinha o porquê ficar preocupada com a postura das pessoas."

A quinta colaboradora, que se autodeclara negra, negou ter sofrido qualquer preconceito racial ao longo de sua trajetória de vida, mas não porque acredita que ele nunca existiu, mas porque, segundo ela, ele é sutil. Afirma ter sempre trabalhado em hospitais privados, tanto como enfermeira clínica como com enfermagem do trabalho, e ter sentindo preconceito em relação a sua estatura e fisionomia. Sobre a experiência realizou alguns relatos. Formada em 1974, relatou ainda ter sido a única enfermeira negra de um hospital onde trabalhava por 24 anos. Afirmou também que, ao trabalhar no setor de Relações Humanas de um hospital privado, observou que algumas enfermeiras negras que passavam pela triagem não apresentavam o perfil esperado pelo hospital e eram logo descartadas, mesmo quando, para ela, esses profissionais tinham o perfil ideal para o trabalho em enfermagem. 


\subsection{Colaboradora 6}

"Etnia quer dizer, pelo pouco que eu sei, tem muito a ver com não só com a cor da sua pele, com toda uma cultura que vem envolvida, junto com aquela determinada quantidade de pessoas, porém, se for considerar o que é dito por aí e o que eu me considero, eu me considero negra."

A sexta colaboradora era recém-formada quando concedeu a entrevista. Discorreu sobre o apoio dos pais na escolha da profissão, mas a mesma só se deu após uma busca sobre as condições de ingresso e o mercado de trabalho para a área. Entretanto, afirmou gostar de cuidar de pessoas e acreditar ter "sangue frio" para atuar. Devido a não inserção no mercado, até o momento da entrevista, a colaboradora se concentrou em relatar episódios de preconceito que ocorreram durante a trajetória acadêmica, relatando, principalmente, episódios vivenciados por outros colegas e por ela observados. Atentou-se também em discutir as condições sócio-econômicas do negro no Brasil, apontando dificuldades que, em seu ponto de vista, geram desigualdade entre os indivíduos brancos e negros. 


\subsection{Colaboradora 7}

"Preto, pardo, negro, pra mim são todos negros. A etnia parda não existe. Amarela existe, é a característica de uma etnia. O branco também. Agora o pardo não, eu acho que a gente está criando uma nova etnia. A etnia dos desestruturados. Então eu acho que o pardo veio muito para dizer que a pessoa tem uma origem mista aí. Mas isso pra mim não quer dizer muito alguma coisa. Não sei se eu também sou um pouco muito radical, mas eu acho também que é uma tentativa de como o moreno veio para tentar disfarçar, é uma tentativa de ser democrático é como o pardo é."

A sétima colaboradora, que na época da entrevista estava inserida no programa de mestrado da Universidade de São Paulo, trouxe a tona a discussão da concepção de etnia e os termos usados para defini-la. Dessa forma, discutiu seu ponto de vista do porque o preconceito se dá de forma velada no Brasil e apontou as dificuldades de combatê-lo e discuti-lo. Relatou algumas experiências em que o preconceito racial se efetivou dentro da EEUSP, por diferentes indivíduos, e admitiu seu medo ser vítima de preconceito ao buscar uma inserção no mercado de trabalho através de instituições privadas. Não deixou de salientar, porém, seu desejo em trabalhar em instituições públicas, preferencialmente de ensino. 


\subsection{Colaboradora 8}

"Sem contar que hospital privado tem que mandar currículo com foto e todas essas coisas. Tem que ser daquele padrãozinho que eles querem. Linda, magra, loira, sorridente. E eu não sou nada disso. Então acho que vai ser mais complicado, mas eu to procurando mesmo assim."

A oitava colaboradora não se encontrava inserida no mercado de trabalho na época da entrevistas, mas relatou, assim como outros colaboradores, seus anseios e preocupações com relação a essa inserção, em especial em instituições privadas, onde acredita que o preconceito racial seja maior. Relatou também que não foi vítima de preconceito racial de forma aberta, mas percebeu atitudes veladas de seus pares durante sua trajetória acadêmica, principalmente por parte daqueles que não percebem que estão discriminando. Afirmou também não partilhar da opinião de que o negro tem que se esforçar mais que o branco para se destacar, entretanto, apontou acreditar que essa é uma realidade se considerarmos as relações de gêneros dentro da maioria das profissões. 


\subsection{Colaborador 9}

"Dentro da universidade eu fui aprovado no vestibular e quando você chega na instituição você tem uma certa autonomia e o respeito que você ganha com a faculdade, então quando você chega em algum lugar de branco é porque você é o cara! Então, por isso que simplesmente a questão de preconceito, eles tratam mal o outro é porque vê que você está mal vestido e não tem posição. Quando você aparece de branco você é o doutor. Fui trezentas vezes chamado de doutor e senhor, então to cansado de ser chamado, inclusive até por pessoas mais velhas, por causa da posição social que você atingiu. E eu acho que não seria necessário isso para você ganhar respeito, mas infelizmente a nossa sociedade vive em torno desses valores $e$ isso acaba me embranquecendo."

O nono colaborador afirmou, à época da entrevista, não estar inserido no mercado dentro da categoria em que se formou, mas relatou experiências de estágio onde vivenciou um "embranquecimento" pelo que acredita ser a posição social atingida dentro da enfermagem. Relatou ainda não ter sofrido preconceito racial dentro da instituição de ensino por acreditar que se impôs frente às possíveis situações, mas salientou o preconceito de gênero sofrido na mesma. Apontou ainda experiências em relação ao preconceito racial vividas no âmbito do dia-a-dia e salientou a luta dos negros e as dificuldades dos mesmos para atingirem postos mais elevados na escala social. Reportou sua experiência de trabalho durante a graduação e como essa atividade prejudicou seu desempenho. 


\subsection{Colaboradora 10}

"Agora, o atual chefe da fiscalização, a gente tem basicamente, nem todo mundo gosta do verde nem todo mundo gosta do amarelo, então ele tem logicamente algumas divergências, mas assim, não acredito que seja por causa do racismo, acredito ser mais assim por ciúme, vontade de estar ocupando aquele cargo o qual eu estava ocupando. Porque imagine eu, uma reles morta, negra, trabalho dentro de uma UTI, ocupando o cargo da presidência, de presidente do Conselho? Então, acho que isso incomodou muita gente, só que não chegavam a expressar, mas que isso era bem nítido, sabe?"

A décima colaboradora, formada no ano 1973, concedeu a mais extensa entrevista do estudo. Com quase 4 horas de duração, discorreu sobre sua trajetória acadêmica e sua trajetória profissional, apontando não acreditar ter sofrido preconceito racial dentro da instituição de ensino, ou de trabalho, mas fazendo declarações que podem ser interpretadas como situações de preconceito mascarado. Relatou ainda as dificuldades encontradas para se manter na profissão, os aspectos históricos da enfermagem no Brasil e sua contribuição para a consolidação profissional. Informou ter sido presidente do Conselho Federal de Enfermagem antes de se aposentar e deixou claro sua paixão pela assistência, em especial pelo trabalho em UTI. Com uma entrevista extensa e detalhada contribuiu não somente para esse estudo, mas também para uma maior compreensão da configuração e trajetória da enfermagem brasileira. 


\subsection{Colaboradora 11}

"Eu acho que o que a gente espera, agora falando das minhas expectativas, é que a gente consiga trazer o jovem negro pra dentro da universidade pública. Porque hoje, e agora eu vou falar da família, dos amigos, os nossos jovens, das nossas famílias, eles estão acessando a universidade, só que a privada. Eles acham que concorrer na USP é difícil, então buscam outro caminho. Muitas vezes, por conta da razão da família, a família banca ele na universidade privada, ou ele tem bolsa. Mas ainda na universidade pública os negros representam uma parcela infinitamente pequena quando comparada ao universo de estudantes que nós temos no ensino médio."

A décima primeira colaboradora se formou em 1979 e, durante toda a entrevista, expressou o apoio que recebeu, em especial de sua mãe, para ser enfermeira. Profissão essa que, segundo ela, foi escolhida após observar uma enfermeira do serviço público em suas ações. Relatou sua militância no movimento negro e sua crença de que os negros têm certa invisibilidade na sociedade brasileira. À época da entrevista se encontrava inserida no programa de doutoramento da Universidade de São Paulo e manifestou seu desejo em trabalhar com docência em uma instituição pública. Relatou ter trabalhado, em sua trajetória, tanto em instituições públicas como privadas, mas manifestou acreditar que os negros são preteridos nos cargos de maior destaque, em especial nas instituições de caráter privado. Salientou acreditar que sempre precisou se esforçar mais para estar em nível de igualdade com os outros colegas, em especial devido as suas dificuldades sócioeconômicas. Não deixou de manifestar seu desejo de ver representantes negros em cargos de destaque, em especial, no cargo de reitor da Universidade de São Paulo. 


\subsection{Colaboradora 12}

"[o preconceito] Foi de uma pessoa especificamente, hoje eu até vejo assim, até como algo que contribuísse para minha maturidade, para que eu realmente me firmar-se dentro daquilo que eu escolhi, e independente da minha cor de pele, porque eu não sou a minha cor de pele, e sou uma pessoa como qualquer outra."

A décima segunda colaboradora, formada em 1989, fez questão de salientar que fez licenciatura em enfermagem, especialização em Saúde Pública, na Faculdade de Saúde Pública da USP, Epidemiologia na Universidade Federal de São Paulo e que, à época da entrevista, estava iniciando um novo curso. Se autodeclarou afrodescendente, mas apresentou certa dúvida em sua colocação. Discorreu sobre a enfermagem e os motivos que a levaram escolher a profissão, afirmando que a mesma "vê o ser humano como um todo". Relatou uma experiência em que acredita ter sido vítima de preconceito racial em uma situação de estágio por um docente da instituição de ensino. Afirmou ainda acreditar que os negros precisam se instrumentar mais para competir no mercado de trabalho e reforçou, diversas vezes, que "o conhecimento não tem cor". 


\subsection{Colaborador 13}

"[O preconceito no Brasil] É um preconceito mascarado. Quando você está no meio social, as pessoas conversam no mesmo grau de condições com você, mas quando você não está com essas pessoas, elas te criticam e falam mal de você."

O décimo terceiro colaborador, formado no ano de 2003, afirmou se autodeclarar negro e acreditar que essa é a melhor forma de se referir a pessoas de sua etnia, pois "os brancos são chamados desta forma e ninguém se sente ofendido". Declarou ter feito licenciatura em enfermagem, residência em enfermagem e, à época da entrevista, estar inserido no programa de mestrado da Universidade de São Paulo. Relatou ainda acreditar que a profissão que escolheu é pouco reconhecida e que há, dentro dela, preconceito de gênero. Relatou ter sentido o preconceito dentro da instituição de ensino, em especial por parte dos colegas, e descreveu algumas situações de preconceito por ele vividas no âmbito profissional e em sua tentativa de inserção no mercado de trabalho. Afirmou ainda não acreditar que o negro não é reconhecido profissionalmente em caráter de igualdade ao branco e que as pessoas, em caráter de igualdade as outras, são capazes de se desenvolverem independente da cor da pele. 


\subsection{Colaboradora 14}

"A gente sente que alguns colegas ficam mais afastados, não convidam você pra trabalhar no grupo deles e coisas desse tipo. E não tem como explicar se não porque eles têm preconceito com a sua cor. Porque uma coisa é você não gostar de alguém porque, sei lá, vocês não se dão bem, as idéias não batem, mas outra é você nunca tentar conhecer aquela pessoa, nem conversar, sabe? Assim, sem nenhum motivo aparente."

A décima quarta colaboradora, formada no ano de 1996, atualmente trabalha em um hospital no interior de São Paulo, mas afirmou, no início de sua carreira, ter trabalhado com home-care e ter sofrido preconceito racial, em especial porque os clientes assumiam que ela, por ser negra, não poderia ser enfermeira. Afirmou que, no princípio, gostaria de ter se formado médica, mas após alguns anos de cursinho resolveu tentar a enfermagem. Após se apaixonar pela profissão continua a exercê-la até os dias atuais. Relatou ter realizado especialização em UTI e desejar se especializar em obstetrícia num futuro próximo. Discorreu sobre o preconceito dentro da instituição de ensino, em especial por parte dos alunos, mas disse não ter sofrido preconceito por parte dos docentes ou dos funcionários, esses últimos, segundo ela, por serem em sua maioria, também negros. Afirmou também acreditar que falta, ao negro, oportunidades para mostrar que é capaz de realizar as mesmas atividades que o branco e que, essas oportunidades, são um passo importante no combate ao racismo. 


\section{RESULTADOS E ANÁLISE DOS ACHADOS REFERENTES AOS DISCURSOS DOS COLABORADORES}

Os discursos dos participantes apresentaram aspectos únicos, singulares e que revelaram as percepções diversas daqueles indivíduos acerca da temática. Nessa perspectiva, é importante salientar que as diferentes interpretações sobre os conceitos de racismo e como as atitudes racistas se manifestam nos meios sociais desses indivíduos foram respeitadas, não foi questionado se as manifestações por eles apresentadas foram ou não efetivamente racistas. Dessa forma, cada excerto traz consigo o ponto de vista do colaborador, carregado, assim, de seus valores e de sua cultura e de sua própria interpretação das dinâmicas e manifestações do racismo no meio em que estavam inseridos.

É importante ressaltar que, apesar de não haver consenso sobre a manifestação de atitudes racistas nas três categorias temáticas definidas a seguir, todos os colaboradores afirmaram terem sido vítimas do racismo, ao menos uma vez, durante suas trajetórias de vida. Outro ponto importante que deve ser salientado nos achados refere-se à preocupação dos sujeitos, que ainda não haviam se inserido no mercado de trabalho, no tocante ao preconceito com relação à sua etnia.

Foram criadas três categorias temáticas que desvelaram o fenômeno perscrutado e seus desdobramentos face às questões norteadoras que foram apresentadas previamente.

\subsection{PRECONCEITO FACE À ESCOLHA PROFISSIONAL}

A enfermagem é uma área da saúde que envolve tanto profissionais de nível médio quanto os de nível universitário. Dentre suas diferentes categorias 
profissionais, percebemos um maior contingente de profissionais negros exercendo funções de nível médio e, dessa forma, pensou-se na hipótese de que a etnia dos sujeitos que escolhem a profissão da enfermagem em nível universitário fossem passíveis de sofrer preconceito racial face à sua escolha. Entretanto, percebeu-se que, no conjunto das entrevistas realizadas, a hipótese concretizou-se em apenas uma fala. Assim, a colaboradora descreveu ter sido vítima de preconceito em sua forma velada, algo que é comum nos discursos dos sujeitos.

"Em determinada parte do curso, ocorreu uma situação com uma docente [...] ela me chamou para o corredor externo, no hospital o qual nós estávamos em prática, e me perguntou se eu não queria desistir do curso! E eu perguntei para ela porque, ela falou que eu tinha que pensar bem, se você quer mesmo fazer esse curso e eu perguntei para ela: 'Professora qual o motivo? A senhora acha que eu não tenho o perfil para o curso?'. 'Não, não, não, não é por isso não'. 'Porque já que vou fazer, que seja bem feito. Se a senhora quer saber, eu prestei vestibular pra enfermagem, e eu já tinha isso definido, e eu entrei como qualquer outro aluno, através de vestibular. E eu me vejo no direito de estudar até o fim'. E porque eu me refiro a isso como um ato de preconceito e, por que eu vejo que sim, porque na mesma semana, em seqüência das aulas práticas, de estágio, na prática como eu disse, ela veio me apresentar, uma chefe de enfermagem, que na época era bem colocado este termo, da UTI em que era uma mulata, afrodescendente, como eu. E aí, para mim foi onde caracterizou ainda mais como um ato de um preconceito[..]. E ela me colocou uma fala assim, 'é eu estou te apresentando ela para mostrar que eu não tenho preconceito'. Então não existia a necessidade de ela ter feito esta colocação. Para mim, eu entendi, como uma atitude de preconceito".(Colaboradora 12)

$\mathrm{Na}$ interpretação da colaboradora, a atitude racista se caracterizou principalmente quando há tentativa da docente em afirmar que "não tem preconceito". Essa característica é muito inerente ao preconceito velado, onde o sujeito que pratica o racismo não é capaz de identificar por si só suas atitudes.

Essa fala sustenta a tese de Freitas (2004), que afirma que a dinâmica do racismo no Brasil gera sujeitos que não reconhecem que praticam, e nem que sofrem, atitudes racistas. Dessa forma, ao perceber que a aluna identificou traços de racismo em sua atitude, a docente passou a perceber seu ato e tentar corrigi-lo. Contudo, o ato 
da docente foi visto, pela colaboradora, como uma afirmação da ação racista realizada inicialmente.

Dessa forma, considerando que um dos pressupostos fundamentais da Teoria Transcultural consiste em que cada cultura tem um modo peculiar e que geralmente é desconhecido por membros de uma cultura diferente, podemos inferir que, se a cultura da aluna fosse melhor explorada pela docente que a acompanhava em estágio, talvez houvesse uma mudança no diálogo, ou na própria atitude, de forma que as diferenças fossem agregadas e trabalhadas no ambiente de trabalho, para que a prática desse sujeito, ainda em formação, se desenvolvesse com diferentes percepções de sua própria cultura e dos outros que a cercam.

Cabe ressaltar que, para Leininger (2006), a cultura é a mais ampla, mais abrangente, mais compreensiva e holística característica dos seres humanos. Dessa forma, sendo o cuidado a mais poderosa e dinâmica força para se entender o ser humano em sua totalidade (Leininger, 2006), negar a cultura do indivíduo seria negar parte daquilo que o faz ser, de fato, um ser humano.

Essa mesma colaboradora relata ainda, em outra passagem, que esse preconceito se deu por outro indivíduo dentro da Escola de Enfermagem.

"Foi de uma pessoa e especificamente hoje, eu até vejo assim, como algo que contribuísse para minha maturidade, para que eu realmente me firmar-se dentro daquilo que eu escolhi, e independente da minha cor de pele, porque eu não sou a minha cor de pele, e sou uma pessoa como qualquer outra." (Colaboradora 12)

Como o estudo é de natureza qualitativa, esperava-se encontrar percepções ou discursos que se contrapusessem. Sendo assim, destacamos uma fala que nega a existência do preconceito nessa categoria de análise. 
"Não [senti preconceito), no ingresso não. Pela escolha [da profissão] também não”. (Colaboradora 6)

\subsection{PRECONCEITO DURANTE O PROCESSO DE FORMAÇÃO ACADÊMICA}

A partir da fala da colaboradora demonstra-se que, no processo de formação acadêmica, o preconceito vivenciado pelos egressos se deu em diferentes âmbitos da instituição de ensino.

"O preconceito vem de todas as partes da comunidade EEUSP, se você tem a pele escura já começam a te chamar de pretinha, se você tem carro ou não tem, a forma de se vestir, as amizades que se faz. O preconceito esta em todas as partes, vai do olhar de cada um." (Colaboradora 2)

Pode-se dizer que a Escola de Enfermagem da USP é uma das pioneiras para a mudança da identidade profissional, agregando em seu quadro discente, logo após sua fundação, pessoas de culturas diferentes da, até então, encontrada entre as enfermeiras formadas no país.

Isso acontece quando, já na segunda turma (1943), a escola contou com a presença de Josephina de Mello, uma aluna bolsista do Serviço Especial de Saúde Pública (SESP), vinda da cidade de Manaus, capital do Amazonas e, conforme consta em sua ficha de admissão, negra. (Souza Campos, Oguisso, 2008).

Entretanto, os relatos de preconceito racial relatados pelos sujeitos dessa pesquisa demonstram que, apesar da abertura da Escola para agregar alunos de diferentes etnias, contextos sociais e diferentes culturas, muito ainda precisa ser pensado na forma de se trabalhar essas diferenças, tanto entre os docentes, quanto 
entre alunos e funcionários.

O racismo foi experienciado pelos colaboradores dentro dessas três esferas, que compõem o convívio acadêmico e que influenciam na formação dos indivíduos.

Podemos citar algumas falas que evidenciam o preconceito exercido por docentes, entre elas, apresentamos primeiramente, o racismo de forma mais explícita e, depois, o racismo em sua forma mais velada.

"Dos docentes a gente sente muito com essa coisa acadêmica assim né, e quando você tenta alguma coisa. Uma vez eu propus pra uma professora e ela tava incentivando a gente a ter novas idéias para um projeto de iniciação cientifica. E ai, uma coisa que me inquietou foi não ter nenhum docente negro. E ai, eu cheguei para falar sobre isso e, assim, foi batata quente que um foi jogando na mão do outro, que ninguém queria falar sobre isso sabe?"

(Colaboradora 6)

"Numa disciplina do $X,[. .$.$] a professora contando um caso importante, de$ uma mulher que teve dois filhos, que era um de cada pai. [...] E ela ainda falou que: 'Foi uma crise na família, porque um bebê nasceu loirinho, de olho azul, lindo assim. Bebê de propaganda. Maravilhoso. E o outro escurinho. Então foi um problema para a família isso'. E foi exatamente assim que ela disse, assim, um bebê loiro, de olho azul, lindo maravilhoso, de propaganda e ou outro era escurinho. Acho que foi um problema, um era negro”. (Colaboradora 7)

Podemos perceber que os docentes mencionados utilizaram seus próprios pontos de vista e discursos culturais para tentar explicar a seus alunos como se configuraram as relações humanas. No primeiro caso, a não abertura para um projeto cuja temática difere das crenças culturais dos envolvidos mostrou que o racismo é algo que não se reconhece na sociedade, e quando se apresenta, por vezes, o faz de forma escamoteada. 
Leininger e Mcfarland (2006) afirmam que estudos focados no cuidado cultural têm apresentado importantes resultados. Esses estudos têm fomentado a transformação do ensino de enfermagem e das suas práticas, segundo essas autoras. Dessa forma, incorporar a discussão sobre as diferenças e as similaridades entre as etnias encontradas dentro de uma mesma profissão pode levar o docente a formar alunos mais críticos e, consequentemente, mais propensos a uma prática humanizadora, pautada no respeito às crenças e valores.

Dessa forma, ao se dizer que a enfermagem é um fenômeno essencialmente cultural, não podemos esquecer que o ensino de enfermagem também o é, sendo assim, deve ser pautado nas diferentes culturas dos indivíduos inseridos no processo de formação acadêmica.

Os próprios colaboradores relataram que, em momentos distintos da história da EEUSP, encontrava-se em seu quadro docente, profissionais negros. Contudo, observa-se pela fala da colaboradora a seguir, que, assim como discentes, o número de docentes negros nessa instituição sempre foi pequeno.

"Já na EEUSP, percebia que havia pouquíssimos negros na sala de aula, somente uma professora em toda a graduação e muitos profissionais de nível médio na escola e, nunca passei por nenhum tipo de constrangimento”. (Colaboradora 4)

Com relação ao racismo sendo exercido por colegas, o número de relatos é maior. Porém, eles se apresentam também das duas formas, explícita e velada, mas, nesse caso, a forma explícita teve maior expressividade nos discursos.

"Eu só comecei a sentir como é muito sério o preconceito, foi quando eu me candidatei para ser o presidente do Centro Acadêmico, [...] e eu tinha mesmo sido eleito como o presidente do Centro Acadêmico, aí eu criei uma séria de novas idéias, entre outras coisas. Entrei e coloquei caixa de sugestões para 
ver o que se podia melhorar no Centro Acadêmico, com sugestões dos alunos. E aí eu comecei a receber um, uma série de bilhetes dentro da caixa, da caixinha de mensagens dizendo: 'Negro onde que já se viu, vou mandar você pra cortar cana, vou votar para voltar a monarquia para mandar você ir cortar cana', e aquilo me afetou muito duro, e por uma ou duas semanas eu fiquei completamente desorientado". (Colaborador 3)

"Comentários que uma menina da nossa classe não poderia namorar comigo devido o fato de eu ser negro e ela branca”. (Colaborador 13)

$\mathrm{O}$ primeiro discurso parte de um enfermeiro negro que migrou para o Brasil de Guiné Bissau e se graduou pela EEUSP no século XX. Sua fala mostra resquícios da escravidão de muitos anos no nosso país. A afirmação do racista de que o colaborador "vou mandar você cortar cana", demonstra que o mesmo julga o outro inferior, não passível de fazer parte de um coletivo como a universidade, que tem como estigma a ascensão social pelo alcance do saber.

O mesmo acontece no segundo discurso, pois, ao afirmar que "uma menina branca não pode namorar um negro", o racista está reafirmando que a pior mistura racial que pode acontecer é de brancos e negros, pois ambos se apresentam nos extremos da pirâmide social construída pelo racismo. Assim, a mistura das duas etnias causaria a degenerescência e o declínio cultural da etnia branca. (Munanga, 2004)

Dessa forma, o racista, ao fazer sua afirmação, baseia no mito construído no século XX de que o negro "não serve pra coisa alguma", desvalorizando o indivíduo como ser único e transportando-o para um grupo desacreditado, que não pode fugir, que ao ser socialmente escravizado o será eternamente, já que sua constituição (o fato de ser negro) a isso o condena. (Memmi, 1993). É assim que percebemos que o racismo foi a ideologia do tráfico de negros que, até hoje, está presente nas nossas relações sociais. 
Cabe dizer que não somente a cultura do negro deve ser observada dentro dos espaços de ensino e de assistência de enfermagem. Pensar a cultura do branco e os fatores históricos e sociais que a influenciam, pode ser uma saída para que se combatam as atitudes racistas, muitas vezes, exercidas por eles. Segundo a Teoria Transcultural, ouvir com a mente aberta, aprender com o outro e não impor nossas ideias e pontos de vista é crucial para que se possa trabalhar a cultura dos indivíduos (Leininger, 2002).

Ainda nessa mesma categoria de análise temos o preconceito exercido pelo corpo de funcionários. Nessa categoria, uma mesma colaboradora apresentou dois relatos muito expressivos. Para ilustrar apresentamos um deles abaixo.

"As mocinhas da cantina até te conhecerem não acham que você é aluno da escola porque você é negro. E é nítido isso. Eu lembro que eu quando entrei aqui eu era mais agressiva para lidar com essas coisas, principalmente porque eu acho que eu não tinha vivido isso, muito. Então acho que o medo na escola enfim, não tinha. Então eu acho que eu já tinha aquela coisa de perceber e se fizer comigo vai levar porrada. E eи lembro que eu soquei a carteirinha na cara da moça da cantina, porque eu lembro que todo mundo tava comprando as coisas sem carteirinha. E aí ela pediu a carteirinha. E aí eu falei: 'Ah, não tá aqui.' Aí ela falou: 'Ah, eu não posso vender sem a carteirinha'. E aí eu lembro que uma colega, ainda, que comprou que estava com carteirinha e ela ainda falou: 'Ah, eu sei que você está comprando pra ela'. E a minha colega respondeu: 'Não eu tô comprando pra mim, eu quero dois'. Mas eu subi com tanto ódio que desci e quase enviei a carteirinha na cara dela e disse assim: 'E aí, tá vendo o a carteirinha?'. 'Tô'. 'E agora você pode me vender?'. 'Agora eu posso'. 'E eu não quero. Você pega e...'. Bem, enfim, foi." (Colaboradora 7)

Assim como na primeira categoria de análise, as opiniões sobre o preconceito racial durante a trajetória acadêmica foram divergentes. Isso pode ser explicado por valores individuais, que podem refletir os valores dos de grupos sociais aos quais pertencemos. Cabe salientar aqui que as percepções sobre o racismo também são subjetivas, determinando assim, diferentes visões sobre uma mesma atitude. 
"[...] Relacionado à etnia aí eu não senti nenhum preconceito não, até porque na sala de aula eu sempre fui representativo assim né, por participar de instituição dentro da faculdade, por representar a sala, nunca senti nenhum preconceito relacionado à etnia”. (Colaborador 9)

"Não, eu acho que não. Porque, naquele tempo, você tinha a doutora $N$ que era negra, você tinha, aquela já morreu [...]. Na minha turma eu tinha $D e$ tinha mais uma outra, mas uma outra menina que eu esqueci o nome dela, que ela era de uma turma anterior a nossa [...]. E, ao mesmo tempo, nós tínhamos aqui na USP, nós tínhamos muitos funcionários negros, então, parece assim, que eles tinham cá comigo, como se fosse assim, um filho que tinha saído de casa e que tava morando aqui. Então, aonde eu ia eles ficavam muito ansiosos, porque eu também sempre fui muito chata pra comer, então, eles falavam: 'Não, você tem que comer..., você vai pra Cidade Universitária, tem que comer ovo de manhã, tem que comer isso, que não sei o quê, sabe?' O pessoal, de um modo geral, se preocupava muito, pelo menos, eu sentia, que se preocupavam muito comigo". (Colaboradora 10)

Cabe ressaltar aqui que vários colaboradores do sexo masculino levantaram a questão do preconceito com relação ao gênero dentro da enfermagem.

"Diz a norma da língua portuguesa que quando homens e mulheres estão presentes, as palavras genéricas devem ir para o masculino, ou pelo menos citar as variações masculinas e femininas e isso raramente acontece na EEUSP. Todos os dias, praticamente, escutávamos ali: "Vocês enfermeiras", "Nós enfermeiras". Isso com homens na sala, fato que incomodava até algumas mulheres, sendo que uma vez vi uma aluna reclamando." (Colaborador $\mathbf{1})$

"Quanto à profissão, o preconceito foi pouco, mas dentro da faculdade mesmo a gente pode falar assim que uma boa parte dos professores pensa que a enfermagem é uma profissão exclusivamente feminina. Aí, na sala de aula, é muito comum você ouvir dizer: 'vocês enfermeira, futuras mães'. Você tem que ficar quieto porque nós somos a minoria. Ou alguns setores, como saúde da mulher e saúde da criança, você chega no campo e aí o profissional da área ou o próprio docente chega e fala 'olha é meio complicado trabalhar aqui ou aqui por causa dos profissionais, aqui você não tem vez', então é uma coisa que eu senti, meio comum assim de acontecer. Até que criança nem tanto, porque de criança é uma coisa que eu até gosto sou até paciente, gostam muito de mim, agora por parte dos profissionais e de alguns docentes isso acontece." (Colaborador 9) 
Pedro (2005) explica que, na língua portuguesa, todos os seres, animados e inanimados, têm gênero, entretanto, somente alguns seres vivos tem sexo. Dessa forma, não há como se utilizar um termo neutro quando temos um grupo onde ambos os sexos estão presentes. Assim, definir as diferenças utilizando-se da palavra "gênero" permite ressaltar que essas diferenças constam nos comportamentos de homens e mulheres e não são, essencialmente, ligadas ao sexo como questão biológica, mas sim, ligadas a cultura.

Entretanto, a palavra gênero começou a ser discutida, em especial, por pessoas dos movimentos feministas, que questionavam o fato de usarmos, tanto na fala quanto na escrita, o termo no masculino plural, quando nos referimos a um grupo de pessoas, mesmo sendo esse majoritariamente feminino, em que um indivíduo do sexo masculino esteja presente. Os questionamentos envolviam justamente o fato de que, essas mulheres, não se sentiam representadas pelo "homem universal" e que, o mesmo, não incluía questões exclusivas das mulheres. (Pedro, 2005).

Por ser uma profissão majoritariamente feminina durante grande parte de sua trajetória histórica até os dias atuais, podemos dizer que a enfermagem contribuiu para a emancipação feminina, mesmo que sua história seja marcada pela dominação masculina, que criou a imagem da enfermeira como dóceis, frágeis, carinhosas e abnegadas (Oguisso, 2007).

Dessa forma, podemos dizer que o homem na enfermagem aparece pela necessidade da força física nas áreas da psiquiatria e ortopedia, ou pela separação dos pacientes em enfermarias conforme o sexo (Costa, Freitas, 2006 apud Pereira, 2001). Assim, na enfermagem, a presença do preconceito com relação ao gênero masculino talvez se dê pela construção histórica da profissão e pela tentativa de manter certos critérios de identidade ainda inerentes à profissão. 


\subsection{PRECONCEITO NA INSERÇÃO PROFISSIONAL}

$\mathrm{Na}$ última categoria de análise nos deparamos com a preocupação dos colaboradores, que ainda não haviam se inserido no mercado, quanto às possíveis manifestações de preconceito relacionadas à etnia. Dentre as falas mais expressivas, apresentamos duas que ilustram essa preocupação com possíveis danos as carreiras profissionais dos sujeitos.

"Eu acho que tem, tem uma dificuldade, dos hospitais $X$ e 'piriri e pororó' que você vê que as enfermeiras são todas com o cabelo bem presinho, na redinha, que elas tentam se padronizar, né? A enfermeira branca, classe média alta, magra... Todos aqueles padrõezinhos bonitinhos da sociedade, perfeitinhos entre aspas. [...] E nestas instituições com certeza eu teria problemas. Tem instituições que pedem currículo com foto, a gente já sabe por que, né? Porque pede a foto no currículo, é um meio de selecionar, é a 'boa aparência'. Tem lugares que com certeza, é nítido se você olhar o corpo de funcionários, que o que contou muito foi aparência. As pessoas são muito parecidas, são muito brancas, não refletem a realidade. É que o discurso de boa aparência abre o espaço para você selecionar as pessoas que seguem o padrão da instituição de classe media alta, muita alta, branca, geralmente loira, alta, magra, se tiver olhos claros é muito bom, né? Porque a boa aparência, quando se discute boa aparência, são pessoas que se enquadram num padrão. Que padrão é esse? Padrão da classe média alta. Padrão europeu de preferência." (Colaboradora 7)

"Eu vou ser bem sincera com você, eu tenho pavor em pensar em entrevista de trabalho pra emprego. Eu to fazendo de tudo assim, to fazendo de tudo para passar em concurso público, para que eu possa passar em todos os processos e que ninguém tenha de olhar na minha cara, e que só saia no Diário Oficial e que fulana passou e tem que entrar tal dia. Em concurso publico, eu acho que é mais fácil você entrar no trabalho que no hospital particular, Porque é assim que você tem que enfrentar a uma prova e depois tem que encara alguém na entrevista assim de frente, sabe? Eu vi isso acontecer com colegas de outros anos deles irem pra entrevista e a pessoa com a mesma capacitação, só porque era branca e tinha um rosto bonitinho uma chapinha á bem feita, sabe? Meninas brancas coisas e tal e a outra pessoa que era negra a menina conseguiu e a negra não conseguiu, sabe?". (Colaboradora 6) 
O medo de que sua capacidade profissional seja julgada pela cor de sua pele é explicado pelo colaborador 9, baseando-se em uma experiência do passado.

“[...] Se você for para pra pensar, você está em igualdade com outra pessoa. Eu nunca ouvi falar de preconceito de branco, agora, assim, pelo que geralmente os diretores, quem vão ser geralmente os brancos, agora que eu te digo se for parar para pensar nisso, é melhor nem sair de casa e procurar emprego, se for pensar nisso, eu prefiro não pensar nisso, deixar de lado. E como eu tive um problema de preconceito no serviço que tive durante a graduação, então eu prefiro não pensar nisso”. (Colaborador 9)

Dentre os que estavam inseridos, ou que haviam tentado uma inserção, no mercado de trabalho, temos algumas falas que sinalizam o preconceito.

"Uma coisa tem me feito pensar que estou sofrendo com isso na vida profissional, mesmo tendo cursado uma das melhores universidades, mesmo passando em algumas provas e entrevistas ainda não fui chamado para trabalhar efetivamente como enfermeiro, só arrumei serviço temporário". (Colaborador 1)

"Eu fui barrado na recepção do Departamento pessoal. Pois anunciaram que os candidatos a enfermeiro júnior poderiam comparecer a uma determinada sala. Então, as pessoas se dirigiram ao local e eu fui barrado. Alegaram se eu não havia ouvido que a vaga era para enfermeiros recém-formados na USP e não para segurança. A seleção para segurança seria realizada em outra sala" (Colaborador 13)

Cabe discutir se esse preconceito inicial não é passível de influenciar a visão e o cuidado que o enfermeiro negro presta em sua vida profissional. Até que ponto o preconceito sofrido influência na assistência de enfermagem? Se partirmos do preceito de que o negro foi discriminado pela sua cor e cultura, onde as instituições deveriam pautar suas escolhas pelas capacidades técnicas e éticas do profissional, não seria possível dizer que o mesmo negro estaria mais propenso, nesse momento, a ignorar a cultura daqueles que ele viria a assistir? 
Tornar-se sensível às diferenças culturais e aplicar os pressupostos transculturais do cuidado exige que os indivíduos, inicialmente, sejam capazes de se perceber parte de uma cultura e, posteriormente, sejam capazes de identificar as outras dentro das similaridades e diferenças no comparativo a cultura onde esse indivíduo se insere. (Leininger, 2006). Ao trabalhar os discursos coletados, percebemos algumas falas que indicam que tanto instituições, quanto funcionários e clientes buscam "branquear" os enfermeiros negros de forma a dar-lhes maior credibilidade.

“Dentro da universidade eu fui aprovado no vestibular e quando você chega na instituição você tem certa autonomia e o respeito que você ganha com a faculdade, então quando você chega em algum lugar de branco é porque você é o cara! Então, por isso que simplesmente a questão de preconceito, eles tratam mal o outro é porque vê que você está mal vestido e não tem posição. Quando você aparece de branco você é o doutor. Fui trezentas vezes chamado de doutor e senhor, então to cansado de ser chamado, inclusive até por pessoas mais velhas, por causa da posição social que você atingiu. E eu acho que não seria necessário isso para você ganhar respeito, mas infelizmente a nossa sociedade vive em torno desses valores e isso acaba me embranquecendo". (Colaborador 9)

"[...] tinha o padrão, que era o padrão do serviço privado. A cor do uniforme, a cor da meia. A cor da meia era cor de mel e eu sou bem pretinha, então por aquela meia cor de mel na perna era muito estranho, era motivo de gozação minha, das minhas amigas, das minhas primas, porque é uma cor de nada, é uma cor muito estranha. Porque era assim que a indústria nos tratava. Nós não existíamos para a indústria de cosméticos, enfim, pra qualquer coisa aí. Então, era muito estranho, se vestir de determinada maneira, usar acessório que eram do padrão da moça branca. O cabelo, eu sou dos anos 60, da geração black power, jamais que poderia usar o cabelo assim, mesmo porque eu seria chamada à atenção. Então tinha que ser o cabelo preso ou alisado. Eu me lembro que eu usava trancinha. Então a supervisora chegou perto de mim e 'Como você faz isso no seu cabelo? Como que é isso?'. Ela não pode me proibir de usar a trancinha porque era muito bonita e chamava a atenção, porque era bonita. Mas era uma coisa que era diferente do padrão daquele local, assim como a cor da meia. Eu comecei a falar da meia, eu respondi uma outra pesquisa e usei o mesmo exemplo. Como eu não gostava da cor da meia eu tingi a meia, e a supervisora viu, e ela me xingou, ela me chamou e perguntou: 'que cor é essa de meia que você usa?' e eu 'eu tinjo a minha meia', aí ela 'procure usar a meia comum'. Porque eu tingia a meia de marrom, porque era o que nós negras habitualmente fazíamos, porque o mercado não oferecia outra cor de meia e 
nós usávamos uma tintura e colocávamos a meia de nylon, no meu caso era meia kendal, que eu também tingia para ficar mais escura e fui chamada a atenção diversas vezes. Então tinha essas coisas, a aparência era essa, de boa aparência era dentro desses padrões de mulher branca, então era isso. Então eu passei a ver a discriminação a partir daí, do local de trabalho. E outra coisa era, quando se dirigiam a enfermeira, que era eu, e eu ia eles olhavam: 'Você é a enfermeira?' As pessoas tinham que confirmar, 'Você é a enfermeira chefe?', então eu 'sim, enfermeira chefe'. Eu tava sempre de crachá, o uniforme era padrão, usava uma cor, a atendente usava uma cor e o uniforme, mas as pessoas precisavam confirmar que aquela pessoa naquele uniforme era a enfermeira chefe". (Colaboradora 11)

"Recentemente eu assumi a gerencia de um hospital aqui do município de São Paulo, então as pessoas se dirigiam á sala de gerencia de enfermagem, que tinha uma secretária, e a secretária anunciava a pessoa. Quando a pessoa entrava na sala da gerente ela só tinha uma alternativa, encontrar a gerente de enfermagem, então a maioria das pessoas perguntavam: 'A senhora é a chefe de enfermagem?'. Então isso denota a surpresa que a pessoa tem em lidar com uma pessoa naquela função sendo negra. Isso agora, em 2002, tem cinco anos. Isso é muito comum, das pessoas. Infelizmente nós negros também nos deparamos com isso em alguns momentos, porque as vezes você vai em algum lugar, por exemplo, é difícil você ir num médico negro, então, se por acaso você for passar em algum lugar e tiver lá uma criatura negra sentada de branco naquele lugar você pergunta: 'você é o que você diz?', porque eu também não estou acostumada a nos ver naquela posição. Isso é comum que as pessoas façam, inclusive nós, porque a gente se vê pouco nesses lugares”. (Colaboradora 11)

Para alguns participantes do estudo existe uma premente necessidade de se provar capaz de estar inserido em determinadas esferas da sociedade, sendo uma delas, a inserção no mercado de trabalho e em determinadas áreas da enfermagem. Essa necessidade é bem explicitada nas falas a seguir:

"Acreditava [que o negro era igualmente reconhecido] quando estava na graduação, mas agora tenho certeza que não. Temos que ter muito mais currículo que o resto das pessoas. Isto para mim é fato". (Colaborador 1)

“[...] A gente enfrenta outra coisa, em relação à discriminação, por exemplo, aqui no meu caso, no serviço público uma insegurança, o paciente nunca acredita em você, que você é capaz como negro, naquela sua formação, então às vezes você é obrigado a mostrar muito mais que isso. Há sim uma 
diferença da forma de discriminação quando você conhece um pouco. Agora existe aquele preconceituoso brasileiro costumas, ele é contra tudo e todos, entendeu? Então esse aí, se você for africano, você pode ser africano, pode ser negro, que não rola. Então tem essas coisas assim.” (Colaborador 3)

"Ah, aconteceu mais de uma vez [situações de preconceito]. Mas elas não me trataram mal, só assumiram logo de cara que, por eu ser negra, eu deveria ser técnica, entende? No hospital também aconteceu a mesma coisa. Mas você se apresenta de uma outra forma e explica quem você é. E quando você diz que se formou na USP, pronto, ninguém mais duvida de que você é mesmo a enfermeira." (Colaboradora 14)

"Eu não tenho vivência profissional, então do vivido eu não tenho muito do que contribuir. Mas eu acho que é uma coisa sim, do próprio preconceito racial, de que você tem de provar que você é competente, porque se espera que você não seja. Eu já ouvi depoimento de pessoas de outras áreas dizendo que tem que provar por 'A mais $B$ ' de que sabe mesmo. E é uma realidade mesmo, aqui no Brasil a gente sabe que as mulheres ocupando o mesmo cargo que os homens ganham menos. As mulheres brancas, porque se for as mulheres negras ganham menos que elas, né. Os homens brancos ganham mais, depois as mulheres brancas, os homens negros e só depois as mulheres negras. Então, pensando nisso dá para tirar mesmo que você tem que provar que você é competente. Em tese você não é, né?”. (Colaboradora 7)

Diversos estudos, ao longo dos anos, vêm provando que, apesar das lutas de classes, os negros ainda ganham menos que os brancos, mesmo em situações em que ocupam cargos semelhantes.

Em 2007, o IPEA (Instituto de Pesquisa Econômica Aplicada) realizou um estudo chamado: "Retrato das desigualdades de gênero e raça", que apontou que a diferença salarial entre mulheres brancas e negras tem como uma de suas causas a discriminação, ressaltando que há mais dificuldade para a mulher negra entrar no mercado de trabalho buscando melhores postos, mesmo em profissões preferencialmente femininas, como é o caso da enfermagem, pois essas mulheres são preteridas dentro desses cargos. Dessa forma, constatou-se ainda, que a mulher negra ganhava apenas $34 \%$ do rendimento médio do homem branco. 
Em 15 de agosto de 2009, o site de notícias UOL, trouxe uma nota sobre a Relação Anual de Informações Sociais (RAIS), do Ministério do Trabalho, que mostrou que a mulher negra ganha, em média, 790 reais, enquanto que o salário do homem branco chega a 1.671 reais. Assim também, a relação apontou que são apenas 498.521 empregos formais para mulheres negras, contra 7.6 milhões de empregos para mulheres brancas. Nessa mesma reportagem foi discutido o $1^{\circ}$ Seminário Nacional de Empoderamento da Mulher Negra, realizado entre os dias 13 e 15 do mesmo mês e ano. Dentre outras discussões, o fórum levantou a premissa de que falta espaço para a mulher negra, não só no mercado de trabalho, mas também no ambiente político.

Essa desigualdade na inserção de espaços sociais é bem marcada pela fala da colaboradora 2, que desacredita que o negro conseguirá se inserir nos espaços em caráter de igualdade com o branco:

"[...] pode ter até mais [graduações] que o branco, mesmo assim o branco vai ser mais valorizado porque vivemos numa sociedade racista e muito preconceituosa”. (Colaboradora 2)

Contudo, na fala de outra colaboradora temos um ponto de vista contrário, entretanto, a mesma define que, para que isso possa acontecer, o negro não pode ter medo de ser vítima de ações racistas.

"Acredito que sim [que o negro é reconhecido profissionalmente], talvez eu possa ser um exemplo de que isso é verdade, é claro que sempre se colocando sem medo de sentir preconceito". (Colaboradora 4)

Para Munanga, em um de seus capítulos no livro "Programa de Educação sobre o Negro na Sociedade Brasileira" (Brandão, 2004), é absurdo pensar que características, como a cor dos indivíduos, possam fazê-los melhores ou piores dentro de uma sociedade. Para ele: 
"Uma sociedade que deseja maximizar as vantagens da diversidade genética de seus membros deve ser igualitária, isto é, oferecer aos diferentes indivíduos a possibilidade de escolher entre caminhos, meios e modos de vida diversos, de acordo com as disposições naturais de cada um. A igualdade supõe também o respeito do indivíduo àquilo que tem de único, como a diversidade étnica e cultural e o reconhecimento do direito que tem toda pessoa e toda cultura de cultivar sua especificidade, pois, fazendo isso, elas contribuem para enriquecer a diversidade cultural geral da humanidade" (p. 24)

Dessa maneira, podemos afirmar que, trabalhar a enfermagem Transcultural pode contribuir expressivamente para que se dissemine o respeito pela diversidade cultural, assim como, contribuir para enriquecer essa diversidade, abrindo novos caminhos para que a profissão cresça como prática social e ciência, ampliando cada vez mais suas áreas de atuações e ganhando mais espaço na sociedade brasileira.

Combater o racismo em todas as suas formas também é algo imprescindível para que a sociedade possa se tornar mais igualitária. Dessa forma, baseando-se pelos três princípios do SUS, a universalidade, a integralidade e a equidade, o Ministério da Saúde lançou, no ano de 2007, uma campanha de percepção e combate ao racismo nas instituições de saúde. 
FIGURA 5 - Propaganda contra o Racismo, Ministério da Saúde

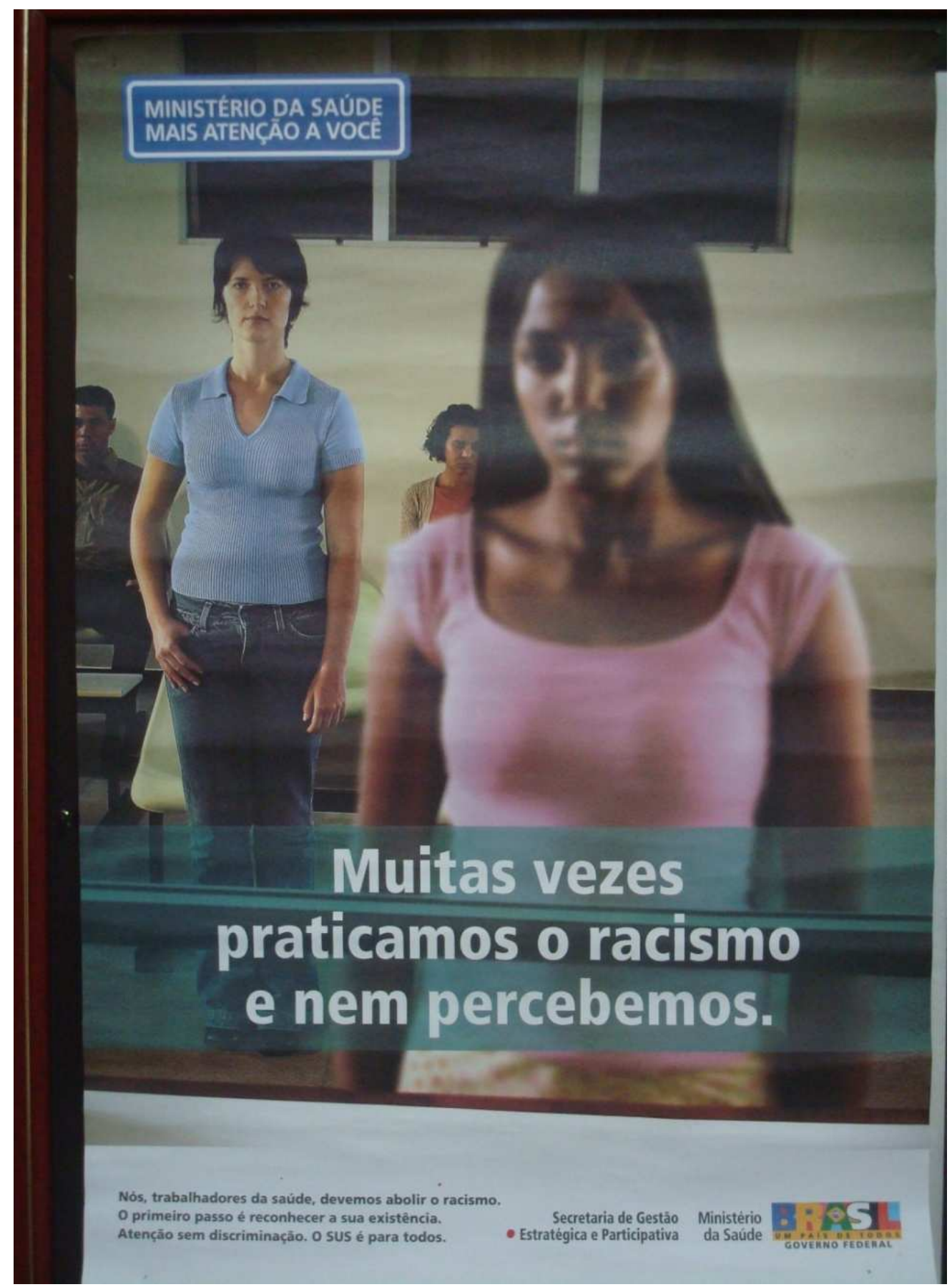

Fonte: Ministério da Saúde, Governo Federal. Brasil, 2007. 
Com os dizeres "Nós, trabalhadores da saúde, devemos abolir o racismo. O primeiro passo é reconhecer sua existência. Atenção sem discriminação. O SUS é para todos", o Ministério aponta que o racismo, de fato, existe na assistência, ao contrário do que acreditava pela teoria da "igualdade racial" brasileira, dando assim o primeiro passo para que sejam combatidas as práticas racistas.

Alguns colaboradores dessa pesquisa também discorreram sobre as formas que julgam mais coerentes para o combate ao racismo.

"Existem maneiras de se combater o racismo sim, elas são amplamente discutidas há muito tempo, o que devemos fazer efetivamente é tentar superar as barreiras que esse preconceito impõe com muito esforço e dedicação, é difícil, mas se ficarmos esperando nada vai acontecer e só vamos ficar nos queixando e tem essa "desculpa" para apoiar nossas decepções." (Colaborador 1)

"Acredito que a melhor forma de combate seja que o negro continue lutando, estudando e principalmente se colocando no mercado de trabalho. É muito importante que o negro tenha bons empregos, boas casas, filhos na escola e poder de compra, porque acredito que o preconceito esteja muito ligado à questão financeira, já que os negros foram libertados das senzalas e ainda hoje tentam encontrar o seu espaço." (Colaboradora 4)

"Sim [há como combater o racismo], mostrando a toda a sociedade que as pessoas recebendo as mesmas condições de igualdade, conseguem se desenvolver, independente da cor da sua pele ou classe social pertencente." (Colaborador 13)

"Acho que as pessoas precisam de oportunidades. E os negros que tem essas oportunidades precisam fazer bom uso delas. As pessoas precisam ver que nós somos tão capazes quanto qualquer um. Só assim eu acho que elas vão nos respeitar, aceitar, entende? Mas pra isso, as pessoas que podem tem que dar uma oportunidade, senão, não faz diferença o negro ir pra faculdade se depois ele não consegue um bom emprego, uma boa chance. Então, eu acho que precisa de uma série de coisas, mas a primeira é oportunidade." (Colaboradora 14) 


\section{CONSIDERAÇÕES FINAIS}

A Transculturalidade do Cuidado, como sugerida por Madeleine Leininger, permitiu observar a dinâmica do racismo na enfermagem como algo que precisa ser ainda melhor pensado e (re)discutido, não somente por professores e alunos, mas também pelos profissionais dessa área e pelas entidades de classe.

A proposta desse estudo foi identificar o racismo dentro da Escola de Enfermagem da USP em suas diferentes dimensões, entretanto, o universo apresentado pelas entrevistas nos mostrou que, apesar de opiniões opostas, os colaboradores apresentam, em algum momento de suas falas, um ou outro discurso racista que vivenciaram mesmo esses não os reconhecendo racistas.

Os achados da presente investigação possibilitaram o alcance dos objetivos concernentes à identificação do perfil sócio demográfico de enfermeiros negros formados pela Escola de Enfermagem da Universidade de São Paulo, no período de 1942-2006; a identificação de processos históricos que contribuíram possivelmente para movimentos de exclusão e inclusão dos enfermeiros negros formados pela EEUSP, no período citado e a análise de situações de preconceito vivenciadas pelos enfermeiros negros face à escolha profissional, sua formação acadêmica e sua inserção no mercado de trabalho por intermédio da oralidade. Cabe pontuar que a perspectiva da Teoria da Enfermagem Transcultural, conforme concebida por Leininger, foi um importante referencial teórico que aportou um novo olhar sobre a problemática estudada, agregando valores à compreensão dos significados do conjunto dos depoimentos dos participantes dessa investigação.

Entretanto, ao finalizar esse trabalho, percebo que despertam outras preocupações e novas observações não pensadas, inicialmente, para o estudo, mas que levam a recriação de um universo que, muitas vezes, não somos capazes de 
perceber com nossos próprios olhos.

É importante salientar que as dinâmicas do racismo são percebidas de maneira diferentes e entendidas subjetivamente. Assim também se dá o estudo das mesmas. Há diversas vertentes para explicar o fenômeno e, algumas vezes, elas se contrapõem de forma a indicarem maneiras diferentes de direcionar o mesmo olhar.

Vale dizer que essas diferenças no olhar podem gerar interpretações distintas de uma mesma temática ou discursos, caso esse que limitou a discussão do estudo levando-me a acreditar que os discursos aqui apresentados poderiam ser revistos e reinterpretados por outra linha de estudo, gerando assim resultados diferentes dos apresentados.

Dessa forma, é importante apontar que a temática do racismo precisa ser estudada e aprofundada cada vez mais, em especial no âmbito da interdisciplinaridade, buscando abrir novos caminhos e incitando diferentes discussões.

$\mathrm{O}$ racismo à brasileira, como dito anteriormente, tem essa característica de criar seres não capazes de reconhecê-lo no dia a dia, afirmação essa que foi verdadeira até a conclusão dessa pesquisa.

Trabalhar as dinâmicas e discursos racistas a partir do ponto de vista daqueles que o sofreram aumenta a percepção de nossas próprias atitudes racistas, muitas vezes, até então, não interpretadas como tais por nós e pelo grupo ao qual participamos. 
A academia tem como uma das suas missões fomentar a discussão no sentido de propiciar a construção do conhecimento a partir da realidade social. Por conseguinte, faz-se mister que corpo discente e docente pensem por si mesmo e discutam os assuntos que os cercam. Esse é um dos pilares da universidade, entretanto, alguns assuntos ainda são pouco discutidos no âmbito acadêmico e, por isso, geram desconforto.

Essa é a realidade do racismo na academia. Pouco se discute, em especial em cursos onde há uma maior preocupação com as questões técnicas, como é o caso da enfermagem. Curso esse que, a partir de seus valores, deveria prezar para o reconhecimento de diferentes culturas e o respeito das mesmas, de forma a tentar construir uma prática mais assertiva e mais abrangente, buscando agregar as diferenças e usá-las como fonte fortalecedora nas situações de cuidado e recuperação dos pacientes.

Dessa maneira, é preciso que cada profissional da saúde reconheça o racismo dentro de suas atitudes e das atitudes de seus pares, apontando-as de forma a salientar sua existência, para que se possa combatê-lo de maneira eficaz e correta, gerando assim, uma assistência mais humanizada e mais transcultural. 


\section{REFERÊNCIAS}

Barreira, IA. A Reconfiguração da Prática da Enfermagem Brasileira em Meados do Século 20. Texto Contexto Enferm. 2005;14(4):480-7.

Borenstein, MS. O uso da história oral como uma possibilidade de reconstruir a história da enfermagem. Texto Contexto Enferm. 1998;7(1):58-70.

Brandão, AAP. (org) Programa de Educação sobre o negro na sociedade brasileira. Niterói: Editora Universidade Federal Fluminense, 2004.

Carrijo, AR. Registros de uma Prática: anotações de enfermagem na memória de enfermeiras da primeira escola nightingalena no Brasil (1959-1970). [dissertação] São Paulo: Escola de Enfermagem, Universidade de São Paulo; 2007.

Carvalho AC. Escola de Enfermagem da Universidade de São Paulo. Resumo histórico - 1942-1980. São Paulo: Escola de Enfermagem da USP; 1980.

Chaverri CE. Historia de la enfermería española e hispoamericana. Madrid: Ed. Universitas; 1995.

Coelho, CP. A escola de enfermagem Anna Nery: sua história - nossas memórias. Rio de Janeiro: Cultura Médica, 1997.

Colliere, MF. Promover a Vida. Lisboa: Lidel, 1999.

Costa KS, Freitas GF. Perfil dos homens formados na Escola de Enfermagem da USP (1950 - 1990). Rev Cultura de los Cuidados 2009;24:38-48. 
Cruz ICF, Sobral VRS. (1995). Nem Ladies, nem Nurses: Sinhazinhas e Mucamas. Por uma re-visão da historia da enfermagem brasileira (e do Sistema de Saúde). Trabalho apresentado na IV Semana Cientifica de Enfermagem, Escola de Enfermagem da Universidade Federal Fluminense. Niterói: 1994. e no $8^{\circ}$ SENPE, Ribeirão Preto. São Paulo: 1995. [citado 15 ago 2010]. Disponível em: http://www.uff.br/nepae/siteantigo/mucamas.doc

Freitas, SM. História oral: possibilidades e procedimentos. / Sônia Maria de Freitas. São Paulo: Humanitas, 2002.

Gualda, DMR. Hoga, LAK. Estudo sobre teoria transcultural de Leininger. Rev. Esc. Enf. USP, 1992;26(1):75-86.

Horta, WA. Processos de Enfermagem. São Paulo: EPU, 1979.

International Council of Nurses. Notes on nursing: a guide for today's caregivers. Geveva; Elsevier; 2009.

IPEA. Retratos da desigualdade de gênero e raça. 2008. Brasília. Disponível em: http://www.ipea.gov.br/sites/000/2/destaque/Pesquisa_Retrato_das_Desigualdades.p df

Jungmann, M. Mulheres negras têm salário menor e menos acesso ao mercado de trabalho. Notícias Uol. [online] 2009 Agosto 15 [citado em 16 agost 2010] Disponível em: http://noticias.uol.com.br/cotidiano/2009/08/15/ult5772u4965.jhtm

Leininger M. A relevant nursing theory: transcultural care diversity and universality. In: Simpósio Brasileiro de Teorias de Enfermagem. Florianópolis, 1985. Anais. Florianópolis, Universidade Federal de Santa Catarina (UFSC), 1985, p. 232-54. 
Leininger, MM. Culture care theory: A major contribution to advance transcultural nursing knowledge and practices. J. Transcult Nurse [periódico na internet]. 2002;13:189. [citado 16 agost 2010] Disponível em: http://tcn.sagepub.com/cgi/content/abstract/13/3/189.

Leininger, MM. Mcfarland, MR. Culture care diversity and universality: a worldwide nursing theory. 2nd ed. Sadbury, Massachusetts: Jones and Bartlett Publishers, 2006

Meihy, JCSB.Manual de História Oral. 4ª ed. São Paulo: Loyola, 2002.

Memmi, A. O racismo. Alfragide (Portugal): Editorial Caminho, 1993.

Minayo, MCS. O desafio do conhecimento: pesquisa qualitativa em saúde. São Paulo: Hucitec, 1994.

Moreira, MCN. A fundação Rockefeller e a construção da identidade profissional de enfermagem no Brasil na Primeira República. História, Ciências, Saúde. 1999;3:62145 .

Mott, M L. Revendo a História da Enfermagem em São Paulo (1890-1920). Cadernos Pagu.2001;(16): 199-234.

Munanga, K. Rediscutindo a mestiçagem no Brasil. Identidade nacional versus identidade negra. $2^{\mathrm{a}}$ ed. São Paulo: Autêntica, 2004.

Oguisso, T. et al. Ano 2030-A aurora da profissão do milênio: enfermagem - uma visão prospectiva de estudantes de graduação em enfermagem. Rev. Esc. Enf. USP. 1999;33(4):384-90.

Oguisso, T (org.) Trajetória histórica e legal da enfermagem. $2^{\mathrm{a}}$ ed. Barueri: Manole, 2007. 
Oriá MOB, Ximenes LB, Alves MDS. Madeleine Leininger and Theory of the Cultural Care Diversity and Universality: an Historical Overview. Online Braz J Nurs [periodico na internet]. 2005 Agost. [citado 16 agost 2010];4(2). Disponível em: http://www.uff.br/nepae/objn402oriental.htm

Paixão, MJ. Desenvolvimento humano e relações raciais. Rio de Janeiro: DP\&A, 2003.

Pedro, JM. Traduzindo o debate: o uso da categoria gênero na pesquisa histórica. Rev História. 2005;24(1):77-98.

Santos, GA. Mulher negra, Homem branco. Rio de Janeiro: Palhas, 2004.

Secaf V, Costa HBVA. Enfermeiras do Brasil: história das pioneiras. São Paulo: Martinari; 2007.

Siles, J. Historia de la Enfermería. Alicante (España): Aguaclara, 1999.

Siles, J. et al. Uma mirada a la situación científica dos especialidades esenciales de la enfermería contemporánea: la antropología de los cuidados y la enfermería transcultural. Cultura de Cuidados. 2001;10(1):72-87.

Souza Campos, PF. Oguisso, T. A Escola de Enfermagem da Universidade de São Paulo e a Reconfiguração da Identidade Profissional da Enfermagem Brasileira. Rev. Bras. Enferm. 2008;61(6):892-8.

Souza Campos, P F. Oguisso, T. Exclusión de mujeres negras. Su Representación en la Enfermería Profesional. Revista Index de Enfermeria. 2006;(55):27-31.

Stewart, I. Dock, L. Por que estudamos a história da enfermagem. Rev. Bras. Enferm. 1977;(30):82-92. 
Thompson, P. A voz do passado: história oral. São Paulo: Paz e Terra, 1992. 


\section{APÊNDICE 1}

\section{TERMO DE CONSENTIMENTO LIVRE E ESCLARECIDO}

\section{Registro dos esclarecimentos do pesquisador aos participantes da pesquisa.}

Eu, Bárbara Barrionuevo Bonini, mestranda em Enfermagem, sob a orientação do Prof. Dr. Genival Fernandes de Freitas, venho convidá-lo(a) a participar da pesquisa intitulada "Ser Enfermeiro Negro na perspectiva da Transculturalidade do Cuidado". Esta investigação tem por objetivos: levantar o perfil sócio demográfico de enfermeiros negros formados pela Escola de Enfermagem da USP no período de 1942 a 2006; descrever questões da identidade do ser enfermeiro (a) negro formado pela Escola de Enfermagem da Universidade de São Paulo, no período citado, a partir da perspectiva da Teoria da Enfermagem Transcultural e analisar as situações vivenciadas pelos enfermeiros (as) negros (as) face à escolha profissional, sua formação acadêmica e sua inserção no mercado de trabalho.

Para tanto, será realizada uma entrevista, que deverá ser gravada, em dia e horário definidos de acordo com a disponibilidade do colaborador do estudo. A entrevista será confidencial, sigilosa e o seu depoimento estará sob a nossa responsabilidade.

O conteúdo da entrevista será utilizado apenas para a realização do estudo, podendo os resultados ser apresentados em eventos e publicados em revistas científicas. A participação dos colaboradores do estudo será totalmente voluntária, podendo os mesmos deixá-lo a qualquer momento que desejarem. Caso aceite participar desta pesquisa, solicito a sua assinatura no item II deste documento.

Desde já agradeço a sua atenção e coloco-me à disposição para quaisquer esclarecimentos sobre a pesquisa. O meu telefone para contato é (019) 9217-2057 e o 
do Comitê de Ética em Pesquisa da Escola de Enfermagem da Universidade de São Paulo é (011) 3061-7548.

O documento será disponibilizado em duas vias, ficando uma delas com o colaborador.

São Paulo, de de 2009.

Pesquisadora

\section{Autorização do colaborador}

Compreendo o objetivo desta pesquisa e concordo em participar de forma voluntária da mesma, entendendo que as informações serão confidenciais, que não haverá identificação nominal e que não sofrerei qualquer tipo de sanção ou prejuízo, caso desista de participar deste estudo. Declaro, ainda, que ao ser convidado a participar desta pesquisa, todos os esclarecimentos foram prestados pelo pesquisador.

São Paulo, de

de 20 .

Colaborador 


\section{APÊNDICE 2}

\section{INSTRUMENTO DE COLETA DE DADOS}

\section{PARTE I - Dados Sócio-Demográficos da Ficha de Admissão}

1. Data de Nascimento:

2. Naturalidade:

3. Ano de ingresso na EEUSP

4. Idade de ingresso na EEUSP

5. Religião:

6. Estado Civil (ao ingressar): ( ) Solteiro ( ) Casado ( ) Divorciado ( ) Viúvo

7. Escolas de Ensino Fundamental e Médio: ( ) Pública ( ) Privada

8. Auto-declaração étnica: ( ) Sim ( ) Não Qual:

9. Identificação Étnica por fotografia: ( ) Sim ( ) Não Qual:

\section{PARTE II - Dados pessoais dos entrevistados}

1. Qual a etnia que você se considera pertencente?

2. Sexo.

3. Ano da formatura.

4. Cursos posteriores realizados e data de conclusão.

5. Você está trabalhando como enfermeiro no momento? Sim ( ) Não ( )

6. Sua família apoiou sua opção de fazer o curso de enfermagem? Sim( ) Não( )

7. Se a resposta for negativa, mencionar os motivos alegados pela família.

8. O que o motivou a fazer curso de enfermagem 


\section{PARTE III - Questões norteadoras}

1. Em que consisti uma atitude preconceituosa para você?

2. Fale sobre a sua escolha profissional e diga-nos se você percebeu algum tipo de preconceito racial ao escolher essa profissão ou ao ingressar na Escola de Enfermagem.

3. Caso você tenha percebido algum tipo de preconceito racial, quais as pessoas ou grupos que teriam manifestado atitudes que você julgou preconceituosa?

4. Quanto a sua experiência profissional, você sentiu algum tipo de preconceito racial enquanto exercia suas atividades como Enfermeiro? 


\section{APÊNDICE 3}

\section{ENTREVISTAS}

\section{Colaborador 1}

Sou da raça negra, me formei em 2004 e não realizei nenhum curso depois da graduação. Decidi fazer o curso de enfermagem após uma conversa com uma exnamorada e tive apoio da minha família na minha decisão. Entrei na EEUSP pelo vestibular universal. $\mathrm{Na}$ minha turma eram apenas 5 discentes que eu considerava negros, não sei se algumas dessas pessoas também se consideravam negros. Só tive uma professora afrodescendente e ela estava fazendo uma espécie de estágio.

Com certeza afrodescendentes é a maneira mais correta [de se referir à etnia]. A palavra "negro" é acompanhada de significados negativos. Entre os meus amigos não nos preocupamos com isso, não usamos a palavra negro e sim preto.

O preconceito existe sim, isto é fato. E é notado ou praticado em maior ou menor escala dependendo de diversos fatores, como região, classe social, locais de convivência, programas na TV. Já vivi, quando criança. Já deixei de ser convidado para uma festa por ser negro. Em rodas de "amigos", com brincadeiras relacionadas à cor da minha pele. Mas isso diminuiu muito, não sei se é pelo fato de freqüentar ambientes onde a raça negra é predominante, ou pelo menos é vista com outros olhos, como rodas de samba, escolas de samba e festas onde músicas estruturadas nos ritmos ditos "Black".

Percebi sim [o preconceito na EEUSP], mas nada relacionado à raça e sim por sexo. Diz a norma da língua portuguesa que quando homens e mulheres estão presentes, as palavras genéricas devem ir para o masculino; ou pelo menos citar as variações masculinas e femininas, isso raramente acontece na EEUSP. Todos os dias, praticamente, escutávamos ali: "Vocês enfermeiras...", "Nós enfermeiras..." ; isso 
com homens na sala, fato que incomodava até algumas mulheres, sendo que uma vez vi uma aluna reclamando.

Não percebi nada na EEUSP relacionado ao preconceito racial, só no sentido sexista. Teve uma vez, logo no começo do curso, em que fiquei sabendo de uma fonte muito segura que havia duas alunas que chamavam a mim e a outra garota de Nescau, nunca chegaram a falar isso diretamente pra mim. Isso mudou com o passar do tempo, tanto é que elas se juntaram ao nosso grupo que ficou formado o restante da graduação. Eu nunca toquei no assunto com elas. Achei que no caso só uma demonstração diferente.

Estou procurando emprego através de concursos públicos. Uma coisa tem me feito pensar que estou sofrendo [preconceito] na vida profissional. Mesmo tendo cursado uma das melhores universidades, mesmo passando em algumas provas e entrevistas ainda não fui chamado para trabalhar efetivamente como enfermeiro, só arrumei serviço temporário. Acho que isso está acontecendo comigo [preconceito racial na iniciativa privada], ou então como explicar o fato de ter passado em provas em hospitais particulares e não ser chamado para entrevistas e escutar de agências de recrutamento que estava tudo certo por parte dela e que era só aguardar o contato da instituição contratante e não ter nenhuma resposta?

Sofri atitudes preconceituosas [no trabalho], sexistas e raciais por parte dos usuários. Um emprego temporário que arrumei era para aplicação de vacinas da gripe em empresas privadas. Não raramente escutava coisas do tipo: No ano passado mandaram umas meninas bonitas, esse ano mandaram um "negão" desse tamanho?!

Não [concordo com cotas para negros]. Concordo com cotas para pessoas que estudaram a vida toda em escola pública.

Acreditava quando estava na graduação [que o negro é reconhecido profissionalmente se tiver a mesma graduação do branco], mas agora tenho certeza que não. Temos que ter muito mais currículo que o resto das pessoas. Isto, para mim, é fato.

Existem maneiras de se combater o racismo sim, elas são amplamente discutidas há muito tempo, o que devemos fazer efetivamente é tentar superar as 
barreiras que esse preconceito impõe com muito esforço e dedicação, é difícil, mas se ficarmos esperando nada vai acontecer e só vamos ficar nos queixando e tem essa “desculpa" para apoiar nossas decepções.

\section{Colaboradora 2}

Eu sou negra. [a maneira mais correta de se referir a pessoas de minha etnia é] Negros. Me formei em 1995, fiz especialização em Saúde Pública em 2002 e em Saúde da Família em 2004. Escolhi enfermagem para ajudar ao próximo. Sim [minha família apoiou minha opção]. Entrei na EEUSP pelo vestibular e concordo com as cotas para negros. O número de discentes negros e brancos não era igualitário na minha turma e eu não vi nenhum docente negro.

Existe sim [preconceito racial no Brasil] e [podemos combatê-lo] dando mais oportunidades para os negros, principalmente quanto a situação financeira. Eu já vivi [o preconceito]. Existe muito preconceito quando escolhermos fazer enfermagem. Muitos dizem que seremos amantes dos médicos ou talvez secretarias deles de forma pejorativa. [Já percebi um tratamento diferenciado] pela gerente de enfermagem por ficar feliz por ter uma enfermeira da USP. O oposto aconteceu com outra enfermeira que discutiu comigo me ofendendo dizendo que eu tinha feito CUSPI.

O preconceito vem de todas as partes da comunidade EEUSP, se você tem a pele escura já começam a te chamar de pretinha, se você tem carro ou não tem, a forma de se vestir, as amizades que se fazem. O preconceito esta em todas as partes, vai do olhar de cada um.

Atuo na UBS durante a semana e em um Hospital nos feriados e fins de semana. Em toda minha historia de vida profissional, me deparei com uma serie de situações, como posso dizer, estranhas. Logo que me formei, eu mandei vários currículos e fui fazer as provas e conseqüentemente as entrevistas. Teve uma vez que fui em uma entrevista para trabalhar em um hospital de renome em sua especialidade, não passei na entrevista pelo fato de colocar o modo que eu penso. Acredito que as pessoas devem ter tido há visão de que eu iria mudar a política de 
enfermagem do hospital, devido a este fato não passei, sei que fui bem na prova e na entrevista tinha apenas quatro enfermeiras. Mas tudo bem, a vida é assim. Eu já estava trabalhando em um hospital há pelo menos 3 anos, teve uma vez que eu não tive folga pela falta de profissional. Trabalhei quase todos os finais de semana, quando me aconteceu a seguinte situação: no hospital tinha uma enfermeira e nós vínhamos de escolas diferentes, por este fato nós nos dávamos super bem, existia uma sintonia muito grande. Éramos apenas nós duas de enfermeiras para o hospital todo. Teve um dia que a chefia chamou a outra enfermeira e disse pra ela que ela estava sendo demitida, logo após a sua saída, me chamaram e disseram que eu também estava sendo demitida, pelo fato de eu ter amizade com a outra enfermeira. Fui demitida sem motivo. A minha sorte é que nesta época eu já trabalhava no PAS. Trabalhei 10 anos num posto onde entrou a Fundação Zerbini com o PSF, fiz vários cursos nesta área e fiz também uma especialização em Saúde Pública, coisa que eu adoro, só que com o passar do tempo, eu vim percebendo que existia uma pressão contra a minha equipe. Só que eu não percebi que a pressão não era em cima de equipe, e sim, em cima de mim. Pois eu ouvia em conversas de corredor, que diziam que eu queria o lugar da direção. Devido a este fato, eu sofri uma pressão muito grande por parte da direção. E eu fiquei tão ruim que eu tive uma alergia. Que quase tive edema de glote. Logo após este fato eu estava de férias e quando voltei eu fui demitida do PSF com a seguinte explicação: que eu não tinha perfil para trabalhar no PSF, esta explicação foi me dada após quase 10 anos de PSF!

Olha, eu fiquei tão abalada por ser demitida desta forma e pelo tempo de trabalho que eu cai em depressão. Eu não queria sair de casa, eu não queria saber de nada. Você trabalhar 10 anos no mesmo local, com quase as mesmas pessoas, e ser colocada pra fora como se fosse um animal? Eu não desejo pra ninguém! Eu tive uma hora pra tirar as minhas coisas da minha sala. Não foi fácil. Ainda me sinto um pouco abalada com toda esta situação. Pergunto eu pra vocês: Que sociedade é esta que estamos vivendo, onde você, que faz uma boa faculdade, tenta devolver tudo que aprendeu de volta pra sociedade só que você é discriminado por pensar assim?

Na minha opinião só existe uma forma de melhorar isso tudo, é mudar a sociedade gradativamente, mostrando pra todos que cada um têm o seu valor independente da pigmentação da pele. 
Sim, [eu sofri com atitudes preconceituosas no trabalho]. Em uma discussão profissional, quando uma enfermeira negra solicitou vaga para minha clinica, pedi para esperar até terminar de fazer a limpeza terminal do quarto. Ela já muito estressada começou a gritar no meio do corredor comigo, relatando que eu tinha feito CUSPI. A mesma se formou na X. Após 1 semana ela veio e me pediu desculpas.

É muito triste ter que concordar com isto, mas ainda acontece [o preconceito na iniciativa privada]. Da minha turma muitas alunas conseguiram facilmente cargo de chefia em hospitais renomados, alunas que não participaram de aulas, que trapacearam em tudo, porém, são loiras. [O negro] não é reconhecido profissionalmente [se tiver a mesma graduação de um branco], pode até ter mais [graduações] que o branco, mesmo assim o branco vai ser mais valorizado porque vivemos numa sociedade racista e preconceituosa.

\section{Colaborador 3}

[Eu sou] Negro. Eu me formei em 2000. Comecei a pós-graduação e parei e agora estou vendo se eu retorno de novo. [Atuo] Como enfermeiro, na área de Saúde Pública no Programa de saúde da Família.

Não, [a minha família não apoiou minha opção] porque eu acho que o meu contexto é um pouquinho diferente, porque primeiro eu vim para o Brasil para fazer o curso de Teologia, e depois surgiu à oportunidade fazer o curso de enfermagem, aí eu fui para a USP fazer enfermagem. Então eu não tive assim um palpite da minha família se deveria fazer enfermagem, ou não, aquela coisa toda. Então é lógico que eu moro aqui no Brasil, minha família toda tá lá. Então quando eu decidi fazer enfermagem foi uma decisão bem madura, adulta, então, eu tava sozinho no Brasil, eu não precisava de ninguém, é claro que precisava, mas só que não tinha como ter opinião. Só souberam quando eu já tava fazendo enfermagem.

É eu não sou brasileiro. Eu sou de Guiné Bissau. Cheguei aqui [no Brasil] em 89 , vai fazer 17 anos. 
Não existe assim um porque enfermagem. $\mathrm{Na}$ verdade eu queria seguir uma carreira de docente, então pra mim tinha que ser, e o caminho mais rápido seria fazer enfermagem, aí depois alguma coisa na área básica, como Fisiologia Médica. Eu gosto muito de Fisiologia, então eu queria depois fazer pós, doutorado em Fisiologia Médica, Anatomia, alguma coisa do gênero, e seguir a carreira docente, e qual o caminho mais rápido pra isso? Enfermagem em 4 anos. Então em 4 anos eu estaria terminando, daria seguimento na minha carreira de docente. Outra coisa também eu avaliei muito a questão do mercado de trabalho, que me daria um retorno rápido, até mesmo pelas necessidades financeiras que eu tinha. Eu não tinha condições de freqüentar um curso mais longo e eu não teria como me manter.

Então, diferença sempre existe. Existe um problema muito grande no Brasil, é que ninguém aborda quem sofre preconceito na pele. Quem não sente sempre dúvida, sempre acha que é uma coisa que só você que está pensado isso, não é bem isso, entendeu? Então as pessoas que praticam na verdade o preconceito no Brasil, sempre são considerados bem intencionados. Então toda a ação de preconceito racial no Brasil, de discriminação racial, ela não tem uma coisa bem declarada. Então não era isso, que a pessoa falhou, não era isso que queria. Então fica aí esse problema, fica difícil de se ter esse equilíbrio, quem não vive fica realmente difícil de definir, que realmente fica difícil de identificar quando que não é mesmo, quando a pessoa está discriminando ou quando é realmente uma questão de intimidade da pessoa com você, por quem é discriminado, e isso é o primeiro passo. Então quando eu entrei, eu era considerado como uma coisa exótica, por ser diferente, de outro país, entendeu? Tem a curiosidade de saber como é que é lá de onde eu vim. Por se Africano, tem então essa questão, e dentro desta questão de ser africano, tem então a questão do negro, da negritude, então o negro africano ele é tratado um pouco diferenciado do negro brasileiro por um simples motivo, ele é um bicho exótico, ele é uma coisa diferente, ele é diferente daquele negro nascido aqui. Então neste primeiro momento, eu não senti, eu só comecei a sentir como é muito sério o preconceito quando eu me candidatei para ser o presidente do Centro Acadêmico, e isso coincidiu naquele período que o Brasil teve, eu não lembro mais o ano, plebiscito para decidir a questão da monarquia, se voltava, se começava o parlamentarismo ou se mantinha o sistema presidencialista. E eu tinha mesmo sido eleito como o presidente do Centro Acadêmico, aí eu criei uma séria de novas idéias para o Centro Acadêmico, entre 
outras coisas. Entrei e coloquei caixa de sugestões para ver o que se podia melhorar no Centro Acadêmico, com sugestões dos alunos. E aí eu comecei a receber um, uma série de bilhetes dentro da caixa, da caixinha de mensagens dizendo: 'Negro onde que já se viu, vou mandar você pra cortar cana, vou votar para voltar à monarquia para mandar você ir cortar cana', e aquilo me afetou muito duro, e por uma ou duas semanas eu fiquei completamente desorientado. E eu fui falar com uma professora muito famosa, que, que pra mim quando eu entrei, era um modelo de profissional, e quando eu fui falar com ela eu fiquei até decepcionado, e me vi chorando perdido no corredor, e aí encontrei outra professora M.

E eu acho assim, que o professor, aquilo que deixa marca, você tem que passar, que é preparar o cidadão para a vida profissional. E educador não é só o que transmite conhecimento, e eu encontrei na M educadora, não só, sabe ela tem um jeito que você olha assim, toda louca. Eu não quero cultuar a $\mathrm{M}$, eu não sei se ela ainda ta lá? Mas, eu entrei, conversei tudo com ela, ela me ouviu, algo assim. Ela não falou nada, me ouviu, abraçou e me deixou sair e eu me senti acolhido naquele momento.

Acho que uma semana depois no refeitório, aonde eu tava com meu grupo, essa pessoa chegou do meu lado e falou assim: 'Eu quero te pedir desculpa, eu não sabia que te dizer. Mas foi a melhor coisa que você fez.' E eu disse: 'Eu não queria conselho, eu só queria alguém pra me ouvir.' $\mathrm{E}$ a outra professora na verdade queria dar conselhos. E como sempre, não é intencional, você tem de passar por cima disso, tem coisas que é efeito psicológico, e você não define, assim, a não, vou passar por cima disso, não existe isso, você tem que enfrentar. Mas a vida toda é intenção. É uma das marcas pra mim muito profundas, quando eu lembro da Escola de Enfermagem fica marcado bem direito. Mas depois, também tem coisas muito boas. As professoras me acolheram muito bem, uma das que fez muito esforço para minha formação foi à professora $\mathrm{F}$, do Médico Cirúrgico, entendeu? E quando decidi para a Saúde Pública, então eu tive ainda mais acolhimento e tive outra visão do que é a sociedade. E eu poderia dar nomes das professoras da Saúde Pública, uma delas já está até aposentada, a, esqueci-me o nome agora, mas são pessoas que me marcaram muito, na Saúde Pública, mas eu não tive, assim, uma boa experiência quando eu passei pelo departamento de enfermagem Médico -Cirúrgica. Embora tinha 
professoras neste departamento, que a $\mathrm{F}$ é um destaque, além da $\mathrm{F}$, tem a da farmacologia, como é o nome dela? S, por exemplo, são pessoas que, pra mim hoje, eu tento não ser elas, mas, ver como a gente pode acolher as pessoas, quando elas chegam. São pessoas que marcaram muito pra mim.

Então, no campo de trabalho eu enfrento muito mais questão de preconceito, que é típico das populações que a gente trabalha, tanta insatisfação, enquanto o problema do preconceito racial no Brasil é uma "raíza", ela é uma coisa social, enraizada na sociedade brasileira, ela se reflete em toda a sua esfera, então quando uma pessoa é discriminada, ela não é só porque ela é de cor, pobre, embora ela tenha uma outra conotação. Quando um sujeito ele tem outra condição social, melhor, ele não é muito discriminado como negro, ele é chamado até de moreno, basta que o Pelé, dizem que o Pelé é moreno. É engraçado, entendeu? Mas, assim, a própria população, às vezes, fica brava e acaba xingando a gente e chamando de negro. É uma coisa. Há duas semanas atrás eu tive um desses problemas aqui, sujeito veio e para passar e eu atendi, eu tava na sala, aí falou um monte que ele era repórter de rádio e ia me fazer perder o emprego e me falou umas outras besteiras mais. Isso é uma coisa comum e a gente consegue contornar.

Em relação à colega de trabalho é isso que eu te falei aqui, por exemplo: eu trabalhei em dois campos, por exemplo, eu trabalhei primeiro por muito tempo no Hospital "x" e agora eu estou aqui pelo "y", é o parceiro com a prefeitura, e eu não tenho sentido isso, mas mesmo assim às vezes, na hora do calor, a agente acaba. Existe também outra questão, devido à própria forma de discriminação a gente fica muito resistente, a gente fica acaba criando uma barreira e fica mais, às vezes, qualquer discussão, que toma um tom mais quente, às vezes, a gente corre, na tentação de achar que é discriminação, mas, nesse sentido aqui. Eu nunca senti nada.

Não [senti diferente em relação a trabalhar num hospital particular] de discriminação, não. Eu trabalhava para o "x", que também era parceiro da prefeitura. Mas então, Hospital Particular eu trabalhei, mas muito pouco, para o Qualis que deu origem ao, não que deu não, que era um projeto o qual inspirou o PSF aqui em São Paulo porque neste tempo já existia no norte e nordeste. Mas assim com o Qualis e que eu é uma espécie de precursor, foi um projeto, que acabou permitindo a implantação. 
A cultura brasileira, não é que tenha se exista [diferença no preconceito quanto ao afrodescendente e o negro brasileiro], mas é como eu te falei, na verdade a questão do preconceito, falar do preconceito, a gente fala assim, parece que tudo que se diz respeito ao preconceito que a pessoa leva como uma coisa racial, só. Preconceito é uma idéia que você pré-concebeu antes e ponto final. Ah existe realmente uma dificuldade muito grande do negro brasileiro, como vocês costumam dizer, afrodescendentes aqui no Brasil, e como o negro é negro, pelo que se espera, porque do asiático você não sabe, porque quando é africano, é africano, então às vezes, no meu caso, porque eu também não posso generalizar, mas quando eles percebem que você é Africano, o tratamento muda, no momento, então tem aquela receptividade, aquela coisa assim, então aí neste momento você parece um bicho de estimação, querido, bonitinho, sabe aquela coisa toda? Incomoda, assim, e quando não se sabe, e aí você percebe e ainda a gente enfrenta outra coisa, em relação à discriminação, por exemplo, aqui no meu caso, no serviço público uma insegurança, o paciente nunca acredita em você, que você é capaz como negro, naquela sua formação, então às vezes você é obrigado a mostrar muito mais que isso. Há sim uma diferença da forma de discriminação quando você conhece um pouco. Agora existe aquele preconceituoso brasileiro costumas, ele é contra tudo e todos, entendeu? Então esse aí, se você for africano, você pode ser africano, pode ser negro, que não rola. Então tem essas coisas assim.

Não [sofri preconceito de colegas de trabalhos]. Em "x" eu tive uma situação semelhante [de preconceito em relação a capacidade], mas me custou muito caro e eu não gostaria de falar sobre isso, porque a gente foi parar no Conselho de Ética e acabei sendo absolvido, e ficou por assim mesmo, eu tinha tudo, tinha toda a papelada se quisesse acabar e entrar com um processo, mas eu achei que ia dar muita dor de cabeça e acabou que eu achei melhor deixar pra lá.

Espero que eu tenha ajudado. 


\section{Colaboradora 4}

[Sou] Negra. Eu, particularmente prefiro ser referida como negra. Também não aceito como preconceito se for referida como afrodescendente.

[Me formei em] 1999. Eu fiz para ministrar aulas, ainda na faculdade a Licenciatura em Enfermagem em 2001 e depois a Especialização em UTI em 2002. [Minha família apoiou minha decisão] Sempre. [Entrei] Pelo vestibular universal. Quando entrei ainda não se falava em cotas. Na verdade ainda não tem cotas na USP, certo? Não [concordo com as cotas], pois acredito que este tipo de incentivo aumenta o preconceito, já que se acredita que os negros só estejam na universidade por causa das cotas; eu penso que todos os brasileiros deveriam ter as mesmas condições de ensino, e assim enfrentar um vestibular universal e como todo outro aluno conquistar sua vaga.

Sim [existe preconceito racial no Brasil], porém hoje com a lei contra o preconceito racial este está velado; mesmo assim ainda existe, não sei como explicar, mas dá pra sentir no olhar quando alguém não te aceita pela cor de sua pele, é muito ruim! Acredito que a melhor forma de combate seja que o negro continue lutando, estudando e principalmente se colocando no mercado de trabalho. É muito importante que o negro tenha bons empregos, boas casas, filhos na escola e poder de compra, porque acredito que o preconceito esteja muito ligado à questão financeira, já que os negros foram libertados das senzalas e ainda hoje tentam encontrar o seu espaço.

Já o vivi [preconceito] diversas vezes pela vida, porém nunca me intimidei e nunca desisti dos meus sonhos e dos meus objetivos. Quando estava no colégio tinha a idéia de fazer medicina, porém estava muito difícil pra mim, já que sempre estudei em escolas públicas; mas não desisti. Também tinha uma prima que já era médica e que me aconselhou a fazer um curso profissionalizante em enfermagem e, foi o que eu fiz, e dai pra frente me apaixonei por este mundo e nunca mais pensei em fazer medicina; então prestei enfermagem e passei. Quanto ao preconceito, como já trabalhava em hospital sempre percebia que os negros quase nunca estavam inseridos em trabalhos de nível superior, havia muitos negros, porém estavam sempre 
envolvidos com trabalhos de nível médio, mas nenhum tipo de preconceito. Já na EEUSP, percebia que havia pouquíssimos negros na sala de aula, somente uma professora em toda a graduação e muitos profissionais de nível médio na escola e, nunca passei por nenhum tipo de constrangimento.

Nunca senti preconceito na EEUSP. Havia cerca de cinco negros para cerca de setenta e cinco brancos. Em toda graduação só tive uma única docente negra.

Sim [sofri preconceito no trabalho]. Por parte dos colegas e usuários. Senti mais preconceito por parte de alguns profissionais de nível médio que não acreditavam que eu era a enfermeira da unidade. Sempre que vinham realizar algum serviço na unidade se reportavam as outras pessoas que se encontravam ali, brancas é claro, e por último por não haver mais opções acabam descobrindo que eu era e enfermeira da unidade.

Uma única vez, os familiares de um paciente não acreditavam que eu era a "enfermeira padrão", e que era eu quem cuidava de sua familiar. Quando chegaram para realizar a visita prontamente fui dar as informações sobre o quadro da paciente, e os familiares ficaram me questionando se eu era mesmo a enfermeira e não técnico que cuidava de seu familiar. Tive que pedir para o médico conversar com a família e ele reforçou que todas as informações já haviam sido dadas pela enfermeira e que não era necessário que fosse tudo repetido e qualquer outra dúvida poderia falar novamente com a enfermeira, que era eu.

Não acredito [no preconceito por parte da iniciativa privada]. Eu acho que têm e deve se colocar no mercado de trabalho e, antes de achar que seu currículo vai ser rejeitado, deve se tentar, deve se encarar como mais um desafio ou meta a ser alcançado. Eu trabalho numa empresa privada e não senti esse tipo de preconceito em nenhum momento.

Acredito que sim [o negro é reconhecido profissionalmente se tiver a mesma graduação de um branco], talvez eu possa ser um exemplo de que isso é verdade, é claro que sempre se colocando sem medo de sentir preconceito.

O que eu sei é que existem pessoas que não gostam e não aceitam as pessoas negras, acredito que por um problema exclusivo delas. Eu não pego isso como se fosse um problema meu. 


\section{Colaboradora 5}

Eu sou negra. Me formei em 1974. Fiz vários cursos na área de enfermagem medicina do trabalho. Minha família apoiou [a decisão de fazer enfermagem]. [Escolhi a enfermagem] Para cuidar mesmo das pessoas.

Não sei se é por isso [por ter a cor da pele mais clara]. Não sei. Eu nunca me disse branca, nunca me considerei, sei lá, a nível de preconceito, porque assim, às vezes as pessoas vêm, na minha família mesmo tem gente que já teve problema, tem problema e é uma coisa concreta, das pessoas falarem mesmo no sentido deles perceberem, sabe? Mas eu nunca... Nem assim no local onde eu trabalhei, pode ser que tenha, acredito que possa ter acontecido, mas foi um a coisa sutil e eu como tava assim, eu me sentia bem fazendo o que eu estava fazendo, sabendo que eu estava fazendo certo, então eu não tinha o porquê ficar preocupada com a postura das pessoas. A nível mesmo de trabalho, a nível mesmo de colegas ou de docentes, nunca tive problema assim. Eu tive problema no começo, às vezes o funcionário me chamava e me apresentava como chefe da unidade, ou às vezes o médico me chamava e me apresentava como chefe e o acompanhante ou o paciente achava que era brincadeira porque eu tinha cara de criança. Eu lembro que tinha a unidade de internação onde eu ficava, eu ficava com 3 andares. Então a gente tinha, às vezes o funcionário chamava porque o médico queria que fizesse alguma coisa que a gente não permitia que fosse feito. Ou ele queria que o funcionário ficasse com o paciente dele o tempo todo. Aí eles falavam que não pode "Como não pode? Ah, chama a chefe". Aí eles me chamavam eu chegava e eles olhavam pra mim e diziam assim: "Você?" Primeiro porque eu era desse tamainho e depois com essa cara de criança então eles, imagina, achavam que eu tava brincando. Então eu dizia: "Sinto muito, mas sou eu!”.

Não [sofri preconceito na EEUSP]. Se teve eu nunca percebi, fui muito privilegiada porque nunca senti nada. Não [percebi nenhum tratamento diferenciado em minha trajetória]. Eu sempre fui reconhecida pelo meu trabalho, fazia tudo direitinho. 
Não [senti preconceito na vida profissional]. Como eu te falei desde que eu comecei a trabalhar foi sempre em instituições privadas. Inclusive eu fui a primeira enfermeira negra do HX. O que acontecia é que eu sempre tive cara de novinha então às pessoas não acreditavam que eu era já formada.

Olha só, deixa eu pegar uma foto da turma pra você ver. Isso aqui era em 74, aqui nós já estávamos saindo. Foi no último ano. Sempre foi um número muito pequeno [de discentes negros]. Eu não sei [porque eram tão poucos].

Não [haviam docentes negros]. Deixa eu ver. Não que eu me lembre. Tem uma pergunta que você esqueceu de me fazer: Porque no HX eu era a única negra. Durante muito, muito tempo eu fui. Durante 20,20,24 é, durante 24 anos eu fui. Olha, eu já estava, pra você quer ver quando entrou, uma nova enfermeira negra, eu já havia ido dar aula na escola então eu tinha pouco contato com os colegas. Então quando eu fui para a medicina do trabalho, eu tive mais contato com os novos funcionários. Porque ainda eu conhecia muitos funcionários. Eu entrava em contato com todo mundo, tá certo? Mas, eu estava mais em contato com o funcionário novo, porque ele passava na entrevista e tinha que fazer exame médico e tinha que levar a carteirinha de vacinação. Quando o Hospital começou a fazer o exame periódico de todo mundo eu pude conhecer o pessoal do meio, porque presta atenção, eu conhecia os mais antigos de quando eu trabalhava na assistência, aí eu fui para escola e perdi o contato. Depois na medicina do trabalho, eu comecei a conhecer só os novos, então com o exame periódico de todos os funcionários é que eu pude conhecer esses do meio. Então entrou, entrou enfermeira negra, mais de uma, duas, três. Que eu diria, não sei se ela se considera, também porque não é nada assim tão negra, de você não ter dúvida não. Depois de 18 anos, se for não, foi menos. E como, porque tem isso, também, como eu fiquei na área de educação continuada, eu fazia a triagem, não era o RH que fazia isso, agora é, antes eu fazia a triagem, eu aplicava o teste, fazia entrevista. Chegou uma hora que eu aprovava estava aprovado. Então teve uma época na minha época, acho que isso aconteceu uma ou duas vezes que tinha enfermeiras negras, mas que não dava para aproveitar, porque não tinha o perfil aceitável. Porque muitas vezes pra mim tinha perfil, mas para o hospital não tinha, então o que fazer? 
O perfil do hospital é assim, por exemplo. A primeira coisa é você ter conhecimento. Você está disposta, por exemplo, no tempo que eu estava lá, você está disposta a se atualizar, tem disponibilidade de pra fazer cursos, quer fazer alguma coisa. Não é enfermeira, porque tem enfermeira que diz assim, "Eu sou enfermeira quero ficar aqui, quero ficar assim”. Tem, é a tal história, porque a gente também não tem bola de cristal, mas tem de ser uma pessoa que tem determinação, que é objetiva quando fala, que saiba, que a pessoa quando for conversar com você imponha a sua opinião, demonstra de que é capaz de discutir com o médico, que não vai baixar a cabeça para médico. Isso era no meu tempo. Mas isso eu percebi que mudou bastante, que com a mudança de direção do hospital, o pessoal de hoje são muito... Eu acho que as enfermeiras de hoje elas são muito. Eu acho que elas abaixam muito a cabeça. Eles querem agora enfermeira novinha, nova e bonita. Porque quando eu entrei, nós entramos na nossa geração questionando. Porque a enfermeira era submissa. Então quando eu entrei no HX era muito complicado porque os médicos antigos não aceitavam isso. Mas a gente achava que você não podia pegar o seu conhecimento e colocar no bolso. Sinceramente eu percebia no hospital vendo alguns acontecimentos que você fala, poxa vida, a enfermeira podia, questionar, perguntar, questionar porque você via algumas coisas, e isso me incomodava, por que na minha época eu perguntava e hoje não. Então eu não sei. Eu já estou afastada mesmo, eu já estou a 3 anos, desde que eu me aposentei e o contato com as enfermeiras que eu tenho já estão afastadas, mas ainda assim, pelo o que eu vejo, as enfermeiras de hoje não questionam mais. Porque também tem aquela picuinha que quando você chega no hospital e continua, mas na medida que você vai questionando ela diminui. Comigo mesmo aconteceu do médico ele te olhava de cima, te olhava assim, e falava: "mas você é enfermeira, o que você tem haver com isso? Fica na sua. Quem é o médico aqui sou eu". Por exemplo, de o médico fazer uma prescrição e você achar que a dose está errada ou ele se enganou, pode acontecer, ele não. Deus, então era complicado, a gente como enfermeira pra gente falar sobre isso era duro! É pior ainda quando era um auxiliar ou um técnico que vem perguntar para você: "É isso mesmo?" É porque está mais você tem que ir no DEF, entrar na internet ver se era isso mesmo, primeiro eu vou me balizar, senão na primeira pergunta você entrega os pontos, né? Então você vê e fala: "Doutor, o senhor tem certeza, eu vou ler o que está escrito aqui”. "Mas eu escrevi isso 
mesmo"? "Bom é tá escrito aqui, a não ser que com essa letra nova..." quanto era médico mais conhecido, que você tinha contato, já tinha brigado então já estava tudo nivelado, aí você ainda podia brincar. É igual quando você recebe prescrição de medicação pelo telefone, aí você pergunta se o médico vem pra cá, se não o que eu vou fazer, vou pedir para o plantonista de plantão prescrever, mas caso contrário eu não vou fazer. A gente só aceitava quando era repetição de alguma coisa, quando era rotina e de um médico confiável.

\section{Colaboradora 6}

O conceito de etnia ele é bastante discutido. Etnia quer dizer, pelo pouco que eu sei, tem muito a ver com não só com a cor da sua pele, com toda uma cultura que vem envolvida, junto com aquela determinada quantidade de pessoas, porém, se for considerar o que é dito por aí e o que eu me considero, eu me considero negra.

Me formei em dezembro de 2006. Não [fiz nenhum outro curso]. Minha família apoiou [minha escolha de fazer enfermagem]. Eu gosto de cuidar de pessoas, e sempre gostei muito da área de biológicas e de humanas e eu descobri que eu tenho certo sangue frio que eu acho que é necessário para se da área de saúde, e ai eu escolhi a fazer enfermagem. Ah, eu fiz uma pesquisa antes de escolher a profissão, eu estava no cursinho ainda e estava indecisa sobre qual profissão escolher para prestar vestibular e motivada pelos conselhos dos professores eu dei uma pesquisada. Como era o mercado de trabalho, salário e vi a dificuldade de passar no vestibular, então eu ponderei por todas as coisas e acabei colocando os prós e os contras em cima da mesa e aí eu acabei decidindo por fazer enfermagem.

Não [senti preconceito], no ingresso não. Pela escolha também não. Bem, no decorrer do curso o que eu observei foi uma indiferença em relação a algumas dificuldades que a gente passa, não porque a gente é negro, necessariamente pela nossa cor de pele, mas mais pela história que a gente tem que e vem envolvida, que vem embutida junto com a gente. Porque, normalmente, sendo você negro você, provavelmente, vem de uma situação desfavorecida economicamente, também, e foi 
esse o meu caso e da maioria dos negros. Aí eu enfrentei algumas dificuldades como morar muito longe e não ter dinheiro para pagar moradia mais perto da universidade e eu não consegui a assistência social da universidade logo de inicio não me ajudou neste sentido de moradia, então eu acabava tendo que me deslocar da longa distância que era minha casa até a universidade e vice versa, gastava muito tempo com isso, era aproximadamente de 5 a 6 horas por dia no trânsito e isso, é lógico, diminuía muito meu desempenho acadêmico também, né? E eu acho assim, que os docentes principalmente os docentes e os colegas também são muito insensíveis a essa realidade. Então eu acho que deveria ter mais, as pessoas deveriam ter uma percepção, acho mais que, mais apurada mesmo dos fatos. Porque eu tenho colegas que realmente passavam por situações que não são situações de igualdade, são situações de desigualdade extrema e que ninguém ta tá nem aí com isso, né? E você é obrigado a ter o mesmo desempenho, estudar bastante pra ter, para poder passar nas matérias e a universidade ainda cobra um alto desempenho, ter nota, você tem que ter nota muito alta para você conseguir várias coisas na faculdade, só que não são dadas às mesmas condições para você e seu colegas, sabe? Já vi colega e, não to falando por mim, necessariamente, mas vi colega que não tinha como necessariamente ter nada para comer e ninguém tá nem ai, e outra coisa, e esses problemas financeiros, esses nossos colegas negros, eu percebi nitidamente, assim problemas com esse mesmo problema financeiro que eu te falei ele se refletiu na nota nos finais de semestre assim que e que a pessoa não passava na disciplina ou que ficava de recuperação ai eu percebi assim uma coisa chata por parte dos docentes de você não ter um apoio, uma ajuda assim por mais que as pessoas não falem, é porque você é negro mais eles não tão nem ai Eu não sei explicar. Tem uma disciplina, por exemplo, uma disciplina no primeiro semestre da faculdade, e que hoje tem outro nome, mas pra gente foi histologia. E, assim, três colegas só ficaram de recuperação e dos três colegas dois eram negros e dos três, os três moravam longe e passaram por problemas. E isso e uma incompreensão muito grande e as pessoas só olham pra si mesmos, e não vêem os outros, não tentam ajudar. Ah, sei lá, estudar, se vê que o outro tá com um pouco de dificuldade, e ter um pouco de compreensão. E acho também que entra um pouco na coisa das fraudes na questão de moradia, né? Eu vi colegas que, uma colega que falou abertamente que tinha fraudado o processo seletivo e conseguiu moradia e outras pessoas que necessitam tanto não conseguem. 
Então, deixa eu ver para eu não perder o raciocínio, não perder o foco, o fio da questão, então no Brasil é difícil você ver alguém te dizer que eu não gosto de você porque você é negro,você esta indo mal por que você é negro.É muito difícil ver uma coisa declarada, você vê a coisa que está encoberta, mas é muito fácil de perceber quando você para e presta atenção

Ah, sempre, sempre [percebi coisas encobertas na EEUSP]. Como eu te falei, porque assim, quando, você enxerga a cor de quem está indo mal, sabe? Indo mal com nota, com o desempenho acadêmico e, sabe? E assim, ás vezes, você percebe que alguns professores dão mais atenção, sabe? E o outro o colega que, sei lá sabe, não dá atenção, eu percebi isso algumas vezes. E, assim, coisas que a gente que é negro vive com isso desde criança, a agente conhece esse preconceito desde criança e muita gente fala, as pessoas não reconhecem, falam que isso é coisa da sua cabeça. Imagina, mas, não é, sabe? Porque assim e como eu te falei não e apenas pela nossa cor. Você tem uma cor, você tem uma condição socioeconômica que é desfavorecida você tem, você já não se veste tão bem, então você vê o tratamento que e diferenciado assim e a pessoa chega e conversa com a professora assim você vê a diferença de uma pessoa que conversa com a professora e você chega, às vezes, com a roupa toda amarrotada, assim, eu já vi até com a roupa um pouco suja, e acontecer de um ver colega assim negro que morava longe, conseguiu moradia, mó luta sabe, e que não tinha dinheiro nem para comprar sabão para lavar a própria roupa e que tava na maior luta e a professora nem deu atenção pra ele e ficou olhando para a roupa que tava suja, sabe? E o cara é muito inteligente, sabe? Muito inteligente, admirável a inteligência dele e a professora nem deu bola pra ele, sabe? E ai você vê que a maioria dos colegas, que são brancos, não é tanto nem pela cor e pelo favorecimento econômico também ai você vê que antes ate mesmo de chegar no docente a 'professora eu queria fazer uma Iniciação Científica com você. Ah, então, é bacana. E você tem inglês? Ah professora, fiz 5 anos de Cultura Inglesa'. E por ai que vai indo. Então e a cor atrelada a essas coisas também a coisa socioeconômica.

Olha a gente sente [preconceito] de colegas, dos colegas a gente sente de alguns grupos que se fecham. Acontece de excluir assim e também por parte dos colegas eles fecham grupos, panelas, assim, que são quase instransponíveis. Ás vezes você e tenta, tenta entrar, mas não consegue. 
Dos docentes a gente sente muito com essa coisa acadêmica e quando você tenta alguma coisa. Uma vez eu propus pra uma professora e ela tava incentivando a gente a ter novas idéias para um projeto de iniciação cientifica. E ai, uma coisa que me inquietou foi não ter nenhum docente negro. E ai, eu cheguei para falar sobre isso e, assim, foi batata quente que um foi jogando na mão do outro, que ninguém queria falar sobre isso.

Disseram que tem uma [docente negra] na pós-graduação, eu não conheço, mas disseram que tem, entre assim, uma centena de professores, disseram que tem uma na pós. São questões históricas [a falta de docentes negros]. E os negros dentro da sociedade brasileira, ele vem cumprindo um papel de marginalidade, um papel imposto por todo o sistema desde a época da escravidão em que houve abolição da escravidão, em que houve a abolição da escravidão, em que os negros, ao invés de terem emprego, a indústria que esta crescente no Brasil, eles trouxeram, os governantes daquela época eles trouxeram imigrantes e na maioria europeus para virem trabalhar aqui no Brasil ao invés de passarem para os negros e darem trabalho pros negros, e dai pro negro vem o retalho de viverem na marginalidade mesmo. De não terem trabalho e de morarem nos lugares mais sombrios e de lotarem as cadeias e etc e tal. E é o que vem acontecendo, porque aquela pessoa tem trabalho e remuneração, o que resta pra essa pessoa é tentar continuar mantendo sua vida e sustentar teus filhos e crescer. E ai são os descendentes que se tem hoje, os descendentes dos brancos. Os descentes dos brancos europeus que vieram para o Brasil e dos negros, dos descentes negros o que é que a gente tem? Eles estão aí penando são os descendentes dos negros que estão penando desde aquela época, desde sempre, desde aquela época em que vieram para o Brasil. Pra gente ficou reservada, que a descendência daqueles negros daquela época e a descendência que esta na favela, que está na favela que é da onde eu vim, que e a descendência de um povo que, até na USP e muito perceptível enxergar que o que foi, o que onde você consegue ver negros é mais dentro de funcionários, assim, que quanto menor for à escolaridade exigida ai que você enxerga esses negros. E quanto mais baixa a escolaridade e isso ai e histórico. Vem desde essa época então na nossa faculdade só tem docente branco então que a as pessoas que tiveram acessos mesmo. Ao, ao ensino e então eles chegaram lá, e pros negros então não é dado nenhum acesso. 
No meu curso nós temos 80 vagas pelo vestibular entramos no primeiro ano. Éramos 80 pessoas e mais ou menos $10 \%$ eram negros. 8, um pouquinho menos. Quase todos, a metade eu acho [se formaram].

Eu acho que quem vai ouvir a entrevista talvez vai dizer que é o que muita gente fala, que é muito, que é muito o argumento classe média branca. E que é que não é uma questão de raça em si, que é um problema socioeconômico, e isso é um fato, essas diferenças socioeconômicas existem e o problema de cor existe muito, muito, mesmo. É complicado e eu não consigo explicar direito. Só quem vive, só quem vive mesmo isso desde pequeno, desde suas primeiras lembranças da infância, sabe entender que esse preconceito, como é que eles são e que e eles existem o tempo todo numa conversa com seus colegas, com seus amigos, com os docentes na escola, com os funcionários etc. Então, eu peço assim que a pessoa que ouça isso não duvide, sabe? Por que isso existe, existe e muito mesmo. Eu não sou agora, como é que eu posso explicar, por exemplo, a gente percebe assim uma preferência muito grande por uma pessoa quando ela tem assim a cútis mais clara. Quando ela tem a cútis mais escura. A preferência de qualquer coisa assim que vá acontecer. Até eu que sou negra, mais tenho a cútis mais clara. Colegas que me dizem, eu já vi, meninas amigas que são mais escuras que eu, sentem mais preconceito que eu. E quanto mais o seu cabelo é mais crespo mais preconceito você sofre. Com piadinhas, sabe? O que as pessoas falam no dia a dia. E, às vezes, te diminuindo tipo, colocando assim: 'Ah, você é morena, moreninha, aquela menina moreninha alta que você ta vendo ali'. As pessoas colocam diminutivos, acho que, para tentar infantilizar ou diminuir a gravidade do que ela ta falando e machuca, sabe? Sei lá, eu acho que parece que pra ela é danoso falar negra, 'aquela menina negra que ta ali'. Como se não fosse orgulho pra mim ser negra, como se fosse ruim pra mim ouvir que sou negra, é a mulata, sabe? Sempre aquele estereótipo de mulata, eu ouço muito isso o tempo todo. As pessoas falam muito isso sem questionar. E tem muito.

Não, ainda não [exerço a profissão]. Eu vou ser bem sincera com você, eu tenho pavor em pensar em entrevista de trabalho pra emprego. Eu to fazendo de tudo assim, to fazendo de tudo para passar em concurso público, para que eu possa passar em todos os processos e que ninguém tenha de olhar na minha cara. E que só saia no Diário Oficial e que fulana passou e tem que entrar tal dia. Isso eu quero dizer assim. 
Em concurso publico é, eu acho mais fácil de você entrar no trabalho, eu acho que é mais fácil você entrar no trabalho que no hospital particular. Porque é assim, você tem que enfrentar a uma prova e depois tem que encara alguém na entrevista assim de frente, sabe? Eu vi isso acontecer com colegas de outros anos, deles irem pra entrevista e a pessoa com a mesma capacitação, só porque era branca e tinha um rosto bonitinho uma chapinha á bem feita. Meninas brancas coisas e tal e a outra pessoa que era negra a menina conseguiu e a negra não conseguiu. Ai, eu não consigo enxergar qual seja o outro motivo desta pessoa não ter entrado sabe? E, na nossa área que é enfermagem, eu acho que os homens negros ainda sofrem mais preconceito, porque a nossa área é uma área assim que a gente lida muito com as pessoas na situação assim mais, muito vulneráveis, e em situação de nudez. Lidar com as mulheres deve ser bastante complicado pros homens principalmente. Mas, então, voltando a historia da questão de trabalho, eu não penso nisso mais, por exemplo, eu gosto do meu cabelo sempre assim mais cheio e se eu for me preparar para uma entrevista, eu já to até pensando nisso, que eu tenho de me cuidar, deixar o cabelo sempre mais baixo, de uma maneira que cause sempre menos impacto porque é pra eles sempre um impacto e é difícil aceitar a gente, aceitar como a gente é e mais fácil aceitar um cabelo alisado que aceitar um cabelo cheio.

Então no meu caso eu não faço no cabelo, eu não gosto de alisar o cabelo porque eu acho que isso é uma filosofia que eu admito. Mais eu acho que a mulher tem liberdade de fazer e que ela quiser! E pode alisar pintar de vermelho, pintar de loiro, eu acho que ela tem liberdade de fazer o que ela quiser. Eu acho que isso não é nenhum pecado em fazer. Eu, particularmente, não gosto da idéia de alisar para ficar parecido com branco. Com as pessoas de pele branca. Se eu tiver de alisar que tiver a fim de fazer uma escova, tudo bem. Vai ser uma fase que eu quero, sei lá, que eu to a fim de mudar um pouco. Mas eu não vou fazer isso porque eu quero parecer com uma mulher branca. E é raro, faz mais de 10 anos que eu não faço uma escova, aliso o cabelo, que eu não faço uma escoava mesmo porque eu gosto é de deixar o cabelo cheio. Mas para uma entrevista, o que eu quero dizer, é deixar o cabelo mais molhado mais baixo, entendeu? Pra causar menos impacto. Porque tem hospitais que eu, incrível ver as pessoas dizendo 'nossa mais só tem funcionário bonito ali'. E o que é bonito pra essas pessoas? Bonito para essas pessoas são pessoas altas, magras, brancas. E tem hospital particular que só tem pessoas com essas características. E eu 
posso te dar com certeza que mais de $90 \%$ da população de funcionários são pessoas que tem essas características que eu to te falando. E você acha que eu não devo ter receio de fazer uma entrevista num lugar desses? E você acha que eu não devo ter receio de ficar desempregada num mercado de trabalho como esse? Que prima pela boa aparência. E que boa aparência é essa? Essa boa aparência que é essas coisas. Então eu prefiro mesmo, tudo que eu vejo falar de concurso publico, eu vou e me animo muito, mas eu prefiro passar pela minha capacidade intelectual do que passar por esses processo seletivos que eu sei que vai pesar, sabe? E não adianta a gente dizer que não que isso, não, porque é uma certeza, sabe? E a cada vez mais com essa historia de mundo globalizado, em que os hospitais também têm que cortar custo e ao mesmo tempo trazer lucro. Então tem cada vez mais essas coisas.

\section{Colaboradora 7}

[Sou] Negra. De verdade, pra mim não faz muita diferença se você me chama de afrodescendente ou de negra. Eu acho que nenhum, eu não enxergo afrodescendente como sendo um termo preconceituoso como você disse que tem uma discussão por causa disso. Muito pelo contrário, eu não vejo diferença, eu me considero negra assim, talvez afrodescendente respeite lá ao meu pai que é branco, me chamar de afrodescendente. Pra mim não faz diferença.

Me formei em 2006. Estou fazendo mestrado aqui mesmo na escola [EEUSP]. Ah, eu acho que sim [minha família me apoiou], mas no eu quis medicina. Eu queria várias coisas e a medicina foi uma delas. E quando eu entrei pra fazer cursinho, medicina foi o que eu queria, uma profissão que tem um status social que a enfermagem não tem, que a maioria das profissões não têm. Como eu estava há 3 anos fazendo cursinho, eu acho que até que a minha família apoiou, médio. Porque quando eu me inscrevi a minha mãe ainda perguntou assim: "Ah você tem certeza?". Apoiou. Mas acho que o resto da família, assim, fora pai assim, acho que todo mundo enxergava enfermagem como um acesso para medicina. Eu acho que na verdade até pouco tempo eu tive de ouvir minha avó dizer que eu sou quase médica, porque agora eu tô fazendo mestrado, depois eu vou fazer doutorado, então, um dia 
eu vou ser médica. Então assim, eu acho que teve um apoio, mas também teve uma expectativa de que a enfermagem seja um acesso. Conhecimento popular sobre a enfermagem mesmo. É um degrau para chegar à medicina. Na verdade eu vim fazer enfermagem porque estava de saco cheio de fazer cursinho, na época eu acho que eu tinha, acho não, eu tinha uma visão muito preconceituosa sobre a enfermagem. Eu queria vários cursos, na verdade a minha primeira opção de início era antropologia, que eu acabei desistindo porque eu achei que eu não ia ter condições de me manter depois, se eu pesquisasse civilizações antigas. Então eu achei que não ia rolar, porque eu sou de uma família pobre e precisava de grana. Então não ia dar para ficar fazendo faculdade a vida inteira. E aí, enfim, como eu gostava de biológicas eu fui lá, medicina, o top. Eu acho que eu queria medicina mais pelo status social também. Que a gente quer. E aí a enfermagem eu acho que entrou no cursinho aqueles, como é o nome? Aqueles testes de psicólogos para falar de profissão.

Eu lembro que eu queria bater na psicóloga, porque ela falava pra mim assim, 'enfermagem, pedagogia, não sei o quê'. E eu achava isso um absurdo: “como assim?". Porque na época o divulgado era pedagogia curso para arrumar marido e eu sou louca para fazer pedagogia, vou fazer um dia e enfermagem era babá de médico, enfim, profissão de frustrado. Essas coisas todas, solteirona. E não é verdade, mas como eu tinha uma visão mais preconceituosa que isso, porque eu achava assim que o único curso da saúde que prestava era medicina, não que prestava, mas que era o melhor porque era o que tinha, eu tinha uma preocupação em ter governabilidade das coisas e a visão é que quem tem a governabilidade é o médico. E, às vezes, é assim mesmo. É a medicina. O resto em alguns lugares é meio difícil de articular assim. E aí eu achava que todos os outros cursos não prestam e enfermagem não é medicina mais presta. Então eu vou fazer enfermagem. Foi assim, com esse pensamento cretino que eu cheguei na enfermagem.

Preconceito em que sentido? Racial? Aqui na escola? Na escola, sim, teve uma, algumas. Uma que eu lembro, naquela semana de recepção de calouros, a gente faz aquele bibliotur. Aquela coisa. Aí eu lembro que elas falaram que tinha um programa de compra de livros na biblioteca, que seria assim, que teria desconto para quem quisesse fazer essa compra. Aí depois, eu e uma estudante que também é negra, e africana ainda, então o preconceito sobre ela ainda é maior, fomos até a 
biblioteca, porque a gente queria ver livro, enfim. E aí fomos até o segundo andar, onde as pessoas que não são da universidade não têm um acesso, porque não tem livro, enfim, elas são mais barradas por lá. Ai eu lembro que teve uma funcionária da biblioteca, diga-se de passagem, a funcionária que nos deu a palestra, ela que é nitidamente afrodescendente, pelo menos, e ela veio com a gente com uma cara de indagação: "Vocês estão perdidas, meninas? Precisam de alguma coisa?" Mas assim, o tom que ela usou era, era nítido que a gente não pertencesse ao espaço. Então a gente deveria estar procurando alguma coisa ou algum livro, enfim, e que não era lá, e ela ia nos encaminhar para o espaço que nos era dado. Teve outra também, é que assim, o preconceito ele aparece disfarçadamente, meio que encoberto. Numa disciplina do X, até, eu acho que era XX enfim, não lembro, a professora contando um caso importante, de uma mulher que teve dois filhos, que era um de cada pai. Enfim, estava discutindo essas coisas. E ela ainda falou que "foi uma crise na família, porque um bebê nasceu loirinho, de olho azul, lindo. Assim bebê de propaganda. Maravilhoso. E o outro escurinho. Então foi um problema para a família isso". E foi exatamente assim que ela disse, um bebê loiro, de olho azul, lindo maravilhoso, de propaganda e ou outro era escurinho. Acho que foi um problema, um era negro. Deixa eu ver. Ah, eu acho que sempre tem, tem assim. As mocinhas da cantina até te conhecerem não acham que você é aluno da escola porque você é negro. E é nítido isso. Eu lembro que eu quando entrei aqui eu era mais agressiva para lidar com essas coisas, principalmente porque eu acho que eu não tinha vivido isso, muito. Então acho que a o medo na escola enfim, não tinha. Então eu acho que eu já tinha aquela coisa de perceber e se fizer comigo vai levar porrada. E eu lembro que eu soquei a carteirinha na cara da moça da cantina, porque eu lembro que todo mundo tava comprando as coisas sem carteirinha. E aí ela pediu a carteirinha. E aí eu falei: “Ah, não tá aqui”. Aí ela falou: “Ah, eu não posso vender sem a carteirinha”. E aí eu lembro que uma colega, ainda, que comprou que estava com carteirinha e ela ainda falou: "Ah, eu sei que você está comprando pra ela". E a minha colega respondeu: "Não eu tô comprando pra mim, eu quero dois". Mas eu subi com tanto ódio que desci e quase enviei a carteirinha na cara dela e disse assim: "E aí, tá vendo o a carteirinha?" "Tô" "E agora você pode me vender?" "Agora eu posso". "E eu não quero. Você pega e...” Bem, enfim, foi. Mas eu acho que dos alunos, não sei. Eu não me lembro. Mas da instituição eu acho que sim. 
[Preconceito durante o estágio por parte de] Usuário, acho que não. Mas de funcionário. No HX, eles sempre achavam que eu era, porque você tem que usar uniforme, então você está de roupa branca, se você está de roupa branca é claro que você é alguém da saúde de lá. Então eu era auxiliar de enfermagem, que era o que me cabia, enfim, você olha lá no HX têm negros trabalhando. Tem. São auxiliares de enfermagem. Não desmerecendo a profissão, mas é uma profissão que exige uma menor formação, são da faxina, da limpeza. Como eu estava de branco não dava para eu ser da faxina porque elas têm uniformes. Então acho que fazendo coisas que eram de atividade da enfermeira. Os outros funcionários mesmo, às vezes negros mesmo, os funcionários, todos, em geral pensam que você é auxiliar de enfermagem, ou se você é estagiária, você é estagiária do curso técnico de enfermagem. No sentido de ser assim que não cabe, não cabe você estar numa universidade que é a melhor do País. Então assim, não cabe.

Então, quando eu entrei, não tinha cota ainda. Tinha cotas só em algumas universidades do Rio de Janeiro, que eu acabei não prestando, até por uma dificuldade minha de lidar com o preconceito. Eu achava que eu não ia dar conta, então, por orgulho meu mesmo, então não. Quando eu prestei vestibular tinha alguns lugares que tinham cota e eu lembro que uma colega minha até que não conseguiu, acabou não passando, mas ela enfim, prestou medicina e foi lá para o finalzinho e quase passou porque tinha cota, ela não era negra, mas tinha uma ajuda para quem era estudante de escola publica. Aí eu lembro que ela falou para mim que como eu era negra ainda ia somar e enfim, mas eu achei que eu não ia bancar, porque as pessoas que estão lá sofrem bastante preconceito. Que estão nestas escolas que tem cota. Eu optei por prestar outra escola que não tinha cotas porque eu também não tinha uma posição política ainda sobre isso e eu preferia passar como os outros. Porque as pessoas entram com uma nota menor e tem toda uma discussão de acesso e permanência, do que te levou a situação de precisar ter um acesso diferenciado, o que eu não tinha na época, eu tinha muito pouco. E, também, eu acho que era muito longe, tinha outras coisas.

Eu acho que capacidade não diferencia em nada. Eu acho que o vestibular que não reflete a nossa educação, que é meramente decorativo, que as escolas privadas são eternos testes. Na verdade não educa, domestica a pessoa a passar no vestibular. 
Acho que não tem diferença nenhuma de quem entrou com cota, quem entrou sem cota, mas poderia ter cota, enfim, eu não vejo a menor diferença nisso. A capacidade não tem diferença nenhuma. O que tem diferença é que a população mais pobre tem uma dificuldade muito grande em acessar a faculdade, nesses modos que a gente tem de poucas vagas, a gente vem de escolas públicas muito ruins de ensino fundamental e médio e isso gera uma necessidade de que a seleção acabe favorecendo um pouco. Não porque essas pessoas não tenham capacidade, mas as escolas que elas estudaram não preparou o suficiente para fazer essa prova ridícula que a gente têm, "decoreba", essas coisas todas que favorecia a classe média e alta branca a acessar a universidade.

A porcentagem [de discentes na turma], bom, negros, deixa eu contar mais ou menos eram 80 e tantos, 85 acho que entraram. Entrou de negros eu, vou fazer a conta, eu acho que deviam ter na minha concepção assim olhando, acho que sei lá, na minha conta deviam ter 8 mais ou menos. O problema é que sei lá, desses 8 ou 9 , quem definitivamente se achava negro era eu mais uns 3 . Eu, um que não tinha como negar mesmo porque era um negro que tinha a pele escura, que a família toda era negra e que não tinha como dizer "não sou negro". E várias outras com chapinha no cabelo, tentando se enquadrar no padrão que se consideravam moreninha. E que tinham até um acesso a bens e serviços e outras coisas diferente que a maioria da população negra. Porque eu era de uma família que já tinha condições sociais melhores. Acho que sei lá, aí era uns 8. Mas a minha turma é a que tem mais. Quase $10 \%$, não é padrão na enfermagem, pelo contrário, o padrão é ter um ou dois.

Procurar emprego eu ainda não procurei. No começo do ano, lá pra março, que eu ainda não sabia se ia sair a bolsa, eu até sai mandando alguns currículos pela internet. Mas foi pouco, e eu tenho uma coisa de que eu não quero trabalhar em hospital, não sei, pode até ser que eu caia lá, mas não é o que eu quero pra minha vida. E eu tenho um problema muito sério com instituições privadas, então eu não pretendo trabalhar num hospital privado. Eu mandei alguns currículos para umas escolinhas aí, mas também as aulas já tinham começado, mas eu mandei currículo. Eu acho que tem, tem uma dificuldade, dos hospitais X e "piriri e pororó" que você vê que as enfermeiras são todas com o cabelo bem presinho, na redinha, que elas tentam se padronizar. A enfermeira branca, classe média alta, magra. Todos aqueles padrõezinhos bonitinhos da sociedade, perfeitinhos entre aspas. Mas por todas as 
coisas que eu acredito, eu não tentaria me inserir nestas instituições por todas as coisas que eu acredito. E nestas instituições com certeza eu teria problemas. Tem instituições que pedem currículo com foto, a gente já sabe por que. Porque pede a foto no currículo, é um meio de selecionar, é a "boa aparência". Tem lugares que com certeza é nítido se você olhar o corpo de funcionários o que contou muito foi aparência, as pessoas são muito parecidas, são muito brancas, não refletem a realidade. É que o discurso de boa aparência abre o espaço para você selecionar as pessoas que seguem o padrão da instituição de classe media alta, muita alta, branca, geralmente loira, alta, magra, se tiver olhos claros é muito bom. Porque a boa aparência, quando se discute boa aparência, são pessoas que se enquadram num padrão. Que padrão é esse? Padrão da classe média alta. Padrão europeu de preferência. E o que mascara? Aí eu não sei. Eu quero trabalhar em instituição pública, de ensino de preferência, que ainda é concurso. Mas assim, tem as OSSs aí que estão virando. Não de ensino mais a as de assistência, então ainda não sei. Não sei como eu pretendo trabalhar em instituições publicas e é via concurso, não sei se terei muitos problemas sobre isso, ainda não sei. Pode ser que sim, concurso pra docente tem aquela prova. Você tem que dar uma aula e tem aquela avaliação bem subjetiva, e essas coisas também podem barrar. Quantas professoras negras você vê aqui na enfermagem? Uma. Tem mais alguma? Você já viu mais alguma na história daqui da enfermagem? Apesar de que também nem podia entrar negro aqui. Sei lá, se bem que os processos não são tão, éticos, mas com certeza são muito melhores do que os processos para entrar na assistência nestes hospitais privados.

Eu não tenho vivência profissional, então do vivido eu não tenho muito do que contribuir. Mas eu acho que é uma coisa sim, do próprio preconceito racial, de que você tem de provar que você é competente, porque se espera que você não seja. Eu já ouvi depoimento de pessoas de outras áreas dizendo que tem que provar por "A mais B" de que sabe mesmo. E é uma realidade mesmo aqui no Brasil, a gente sabe que as mulheres ocupando o mesmo cargo que os homens ganham menos. As mulheres brancas, porque se for as mulheres negras ganham menos que elas. Os homens brancos ganham mais, depois as mulheres brancas, os homens negros e só depois as mulheres negras. Então, pensando nisso dá para tirar mesmo que você tem que provar que você é competente. Em tese você não é. 
Acho que o preconceito é velado. Você quer saber se é pior, ou melhor, né? Não é uma criação, e eu acho que a gente sente assim o preconceito é nas pequenas coisas. Quando a professora que fala bebe lindo, branquinho, loiro, de olho azul e bonito, uma maravilha e o outro um escurinho é um problema. Acho que isso reflete um preconceito muito grande. Não sei se ela sabe que tem esse preconceito ou não. Mas que isso reflete, reflete. Quando você vê uma propaganda na televisão que diz que o sol nasceu para todas, mas só tem mulheres brancas. Reflete. Porque o céu nasceu para todas, mas de que "todas" estamos falando? É acho que negros. As negras não existem ou a gente exclui? Reflete um preconceito que está velado, tanto que a gente tem uma Lei contra isso, só que acho que pela própria mestiçagem que aconteceu forçada, os próprios negros no Brasil, acho que pelo fato de terem sido escravos e a abolição do modo em que aconteceu, tem uma auto-estima muito baixa. Não sei até que ponto as pessoas conseguem discutir sobre isso. As pessoas da minha sala o pai é negro e fala que meu pai é moreninho e eu sou, eu sou morena, ah, o meu cabelo é cacheado. A pessoa não consegue entender. Porque não é legal ser negro nesta sociedade. É melhor ser enquadrado. Se você não se enquadra você tem outros prejuízos. Não sei dizer se é melhor ou se é pior, mas eu acho que quando você tem declarado como tem nos Estados Unidos, por exemplo, que é nítido. Acho que eu consigo enxergar lá que o movimento negro é muito mais forte, eles têm um poder de reivindicação muito maior tem umas discussões muito mais profundas. Eu estava em contato com algumas pessoas do Canadá, negros, que vieram para cá e discutiram essas coisas, é muito mais forte. É de massa mesmo. A gente tem um movimento negro forte, mas a maioria nem sabe o que acontece, então eu acho que talvez o preconceito declarado faça com que as pessoas saibam melhor como lidar com isso. Faz até com que os brancos entendam que isso não deveria existir. Então abre até um maior espaço para discussão e reivindicação, aí. Agora, não sei também se é melhor, acho que tem ônus e bônus aí. Porque acho que as pessoas conseguiram se articular melhor porque nestes lugares onde o preconceito é maior não tem como não se ver como negro. Não tem o disfarce. Você é negro então você está excluído assim. Então você está excluído literalmente, assim fez com que as pessoas se organizarem mais, se mobilizarem mais, diferente do que há aqui. Fez contra a auto-estima mesmo, assim. Então não é mais difícil de trabalhar. Eu acho assim, que talvez para se organizar seja melhor. Mas não sei. Acho que para a organização. E também, tem 
aquilo de você saber quem é o seu inimigo. Então a coisa assim fica muito mais clara. Aí você sabe quem com quem você tem que discutir, com quem é o embate e aqui você não tem. Aqui a pessoa: “Ah, eu adoro gente negrinha. Eu adoro gente escurinha. Ah, eu queria ser moreninha que nem você”. É aquela coisa, é muito disfarçado, a gente tenta ter a política da boa vizinhança e é mais difícil lidar com isso. Porque quando você sofre um ato preconceituoso de fato e que está claro que é aquilo, é muito mais fácil reagir do que quando é mascarado. É nessa, nessa aula, eu fiquei indignada e sai. Eu nem consegui discutir, porque estava muito velado. Eu acho que só eu e mais dois perceberam porque estava uma coisa tão velada. Se fosse uma coisa clara, mais clara talvez tivesse doido mais, mas teria tido uma reação. Teria aberto para discutir, não sei se bom, não sei se seria uma boa discussão, mas teria aberto para discutir.

Então, na verdade acho que no Brasil é o único país que a tonalidade da pele muda muito. Acho que fora do Brasil a gente tem um preconceito que é preconceito puro. Se seu tataravô é negro você é negra, as pessoas te identificam como negro você é apontado como negro. Aqui não, aqui, o que conta mesmo, o que identifica é a cor da pele, as pessoas falam assim: “Ah, você é moreninha. Você não é negra”. Já falaram pra mim que eu sou moreninha, que eu não sou negra. "Imagina, você não é negra, você é moreninha". Eu falei: "Não. Você é morena. Eu sou negra". Eu acho que é por isso, como aqui as pessoas são classificadas pela cor da pele, se você sai um pouquinho mais clara você é moreninha, se mais clara ainda você é branca de cabelo cacheado. É o preconceito aqui é pelo tom da pele mesmo. E quando você é um pouco mais clarinha e tem cabelo cacheado tem que fazer chapinha para ficar mais branquinha. E em outros traços que são mais claramente identificados, eu acho que até população brasileira por ser muito miscigenada, os outros traços que identificam os negros estão presentes na população em geral, então os lábios grossos, o nariz, o corpo enfim. Está presente em pessoas em que o avô é branco e ela nem sabe quem é negro na família dela, então se eu sou branco e meu avô é branco, então eu sou branco, pra mim. Se é mais escura, são negros. Se for mais escura, escura, porque senão você ainda assim não é negro.

Então quando a gente reafirma o ser negro a gente reafirma a nossa origem, étnica, enfim, os meus ascendentes vieram da África sim, vieram ser escravos aqui 
sim, é uma origem. E ser moreno, eu acho que, a minha concepção de moreno é alguém que foi para praia e tomou sol ou alguém que é branco e saiu com o cabelo escuro. Esse é o moreno, é o branco de cabelo escuro. Tem o loiro, loiro é o branco de cabelo claro, e moreno é pó branco de cabelo escuro? Ou que tomou sol, enfim, não tem uma identificação étnica. Acho que é como dizer loiro, dizer ruivo, o loiro e o ruivo são pessoas brancas, mas a cor do cabelo é diferente, um tem uma manchinha aqui ou outra, mas não representa uma etnia. O moreno é a mesma coisa. E o moreno, acho que aqui no Brasil, o moreno é usado para "desrraçar". Acho que as pessoas não querem mostrar que são preconceituosas e mostram dessa forma, chama de moreno. Enfim, se elas se sentem politicamente corretas e não são preconceituosas porque elas não falam negra que parece uma ofensa. Assim você tenta tapar um preconceito com outro, o mesmo. Então você camufla o preconceito de uma forma que ele fica menos visível.

Eu acho que algumas coisas são preconceituosas, outras não. É uma denominação de cor que não reflete a realidade. As pessoas negras não têm uma cor de pele preta. Preta no sentido de cor, por mais pele escura que seja está muito mais próxima do marrom do que do preto. Eu acho que tem essa diferenciação no sentido de cor, assim como as pessoas brancas não tem a cor da pele branca cor de papel. Não sei se você está conseguindo entender. Independente de ser próximo ou não é um termo usado para identificar a cor da pele, não sei, pra mim não é. Eu não me incomodo de ser chamada de preta. Acho que como foi dada aqui no Brasil, apesar da cor de pele ser mais próxima do marrom, eu acho que chamar de marrom aqui no Brasil é preconceito. Eu acho que alguém te chamar na rua de marrom. Pelo jeito que se dão as coisas no Brasil eu acho que é preconceito. Que é como a palavra chata é preto, chamar de marrom pra mim já é disfarçar. É como chamar de moreno, amenizar. É aquela classificação tosca do IBGE. Preto, pardo, moreno, a cor da pele não é o que determina a etnia. Isso é que é importante, as pessoas sofrem o preconceito no Brasil devido a cor da pele. Isso é fato, as pessoas que tem a pele mais escura são as pessoas que sofrem mais preconceito, mesmo assim, os descendentes que são mais clarinhos são sofrem todos os problemas sociais criados pelo jeito que se deu da escravidão pra cá. 
Bem, eu acho que, enfim, preto, pardo negro, pra mim são todos negros. A etnia parda não existe. Amarela existe, é a característica de uma etnia. O branco também. Agora o pardo não, eu acho que a gente está criando uma nova etnia. A etnia dos desestruturados. Então eu acho que o pardo veio muito para dizer que a pessoa tem uma origem mista aí. Mas isso pra mim não quer dizer muito alguma coisa. Não sei se eu também sou um pouco muito radical, mas eu acho também que é uma tentativa de como o moreno veio para tentar disfarçar, é uma tentativa de ser democrático é como o pardo é. Se o pai é branco então você não tem o ônus de ser negro então eu acho que é muito mais nesse sentido. Hoje quando você vai registrar uma criança no cartório, eles perguntam para o pai, mas quando eu nasci na época o cara olhava. Então a minha certidão de nascimento veio numa época em que já não se colocava mais. Mas a minha irmã, eu não sei por que cargas d'água colocaram branca. Porque meu pai é branco, mas a minha irmã não é branca, a minha irmã é negra. E da outra irmã está escrito parda. E na minha não está escrito nada. Então eu acho que essa ignorância total de quem trabalha nesses lugares. E não sei também porque tem que estar escrito na certidão de nascimento.

\section{Colaboradora 8}

Sou Negra. Acho que afrodescendente é aquela pessoa que tem ancestrais que vieram da África, certo? Se você considerar que todos os negros que vieram para o Brasil vieram da África, então acho que todos somos afrodescendentes, mas eu não gosto dessa denominação. Sou negra. Acho muito mais bonito se referir à pessoa negra como negra. Não acho que é preconceito usar a palavra negro.

Me formei em 2005. Ainda não [fiz nenhum outro curso], mas pretendo fazer mestrado o mais cedo possível. Por enquanto estou apenas procurando trabalho.

Acho que a minha família apoiou sim [minha decisão de fazer enfermagem]. Ainda acho que a minha mãe me queria ver médica ao invés de enfermeira, mas eu prefiro assim. Não que ela seja contra a enfermagem, mas sabe como é, médico ganha mais que o enfermeiro e tem mais status, então os pais sempre querem que os 
filhos sejam os melhores e tenham melhores condições do que eles, por isso eu acho que ela pensa assim. Mas minha família sempre apoiou a minha decisão. Eu só sabia que queria um curso da saúde, mas não sabia se era medicina ou não. Então foi meio que por eliminatória, sabe? Aí eu entrei e gostei do curso. Depois que você conhece você acaba se apaixonando.

Pra escolher a profissão? Ah, sempre tem [preconceito]. Todo mundo acha que você vai fazer enfermagem pra fazer medicina. Como se a enfermagem não fosse uma boa profissão. Ou então que você quer fazer enfermagem pra casar com um médico, essas coisas. Mas a gente se acostuma com isso depois. Agora, dentro da escola, você diz preconceito racial? Acho que teve alguma coisa sim, mas não vou lembrar agora. Acho que [veio] dos colegas mesmo. Não lembro de docente nenhum me tratar com preconceito, mas porque isso é meio subjetivo. Ás vezes a pessoa faz um comentário, mas não porque ela é preconceituosa, mas porque, sei lá, ela ta acostumada. Coisa que você escuta a vida inteira e fica enraizado dentro da gente. Mas não lembro de nada que tenha me atingido pessoalmente.

Conhece aquele ditado que diz que segunda-feira é dia de branco? Então, coisas assim. Não acho que todo mundo que diz isso é preconceituoso, mas se você reparar bem é um ditadinho bem preconceituoso sim. Porque o negro também trabalha tanto quanto o branco, ás vezes até mais, então porque a segunda-feira não pode ser dia de negro? Mas acho que foram só essa coisas. Coisas que a gente que é negro percebe, mas a pessoa que não é, que nunca sofreu preconceito nem percebe.

[Entrei na EEUSP] Pelo vestibular da FUVEST mesmo. Acho que é o único jeito. Na minha época não tinha cotas ainda. Acho que na USP ainda não tem. Acho que é só pra quem veio de escola pública. Nada a ver com a raça. Olha, eu conheço uma pessoa que entrou numa universidade pelo sistema de cotas. Não sei se é errado, porque querendo ou não, o sistema dá uma ajuda praqueles que não tem tanta facilidade de acesso assim. Só que eu acho que as cotas poderiam ser só pra quem fez a escola pública. Sem essa de negro ou branco. Porque quem estudou em escola pública é porque não tem acesso a escolas melhores, não importa se é negro ou não. E depois, se você passa pelo sistema de cotas fica aquela marca sabe: "Fulano só ta na universidade porque é cotista”. Isso não é bom. 
Acho que vai ser feroz [o mercado de trabalho]. Eu queria mesmo era fazer o mestrado e depois passar em concurso público, porque aí você tem toda uma estabilidade que as instituições privadas não te dão. Lá eu acho que é mais difícil conseguir emprego, apesar do salário ser muitas vezes maior. Sem contar que hospital privado tem que mandar currículo com foto e todas essas coisas. Tem que ser daquele padrãozinho que eles querem. Linda, magra, loira, sorridente. E eu não sou nada disso. Então acho que vai ser mais complicado, mas eu to procurando mesmo assim. Eu não tenho experiência profissional, mas eu já estive nesses hospitais. Você chega lá e você percebe que as características físicas influenciam na hora de conseguir o emprego. Todo mundo tem assim, o mesmo molde.

Olha, a gente sabe que tem poucos negros assim, em cargos de respeito. Que são chefes, donos, gerentes, essas coisas. Mas se você pensar bem, também tem pouco negro bem, assim, qualificado pra esses cargos. Nem to falando no sentido de capacidade, é mais no sentido de que, tem menos negros em universidades, como por exemplo, a USP, a Unesp, essas públicas. Onde o ensino é melhor, onde o diploma pesa mais. Então eu não acho que o negro tem que fazer mais e coisa e tal. Não acho que eu tive que estudar mais do que alguma menina branca da minha sala porque sou negra e ela é branca. Acho que o negro tem que estudar pra provar que é bom, que é capaz, assim também o branco, o amarelo, o indígena. Porque o mundo é competitivo. Então o que serve pra mim, como mulher negra, também serve pra uma mulher branca. Acho que, profissionalmente, a mulher tem que batalhar mais pra ganhar o seu espaço. Talvez não na enfermagem, porque é uma profissão predominantemente feminina, mas, por exemplo, nas profissões dominadas por homens a mulher tem que correr atrás, porque ela vai encontrar um monte de homens querendo puxar seu tapete. Acho que é isso.

Eu não acho que vou ajudar muito, porque eu não sou muita atenta nesse negócio de preconceito. Graças a Deus isso não acontece comigo, mas eu sei que acontece com bastante gente. Eu só acho legal vocês fazerem essa pesquisa pra mostrar pras pessoas que tem bastante negros por aí que são formados na universidade e que mesmo assim sofrem preconceito. E o preconceito é um negócio tão bobo. Mas enfim, eu acho que era só isso mesmo. Boa sorte na pesquisa. 


\section{Colaborador 9}

Sou Negro. Me formei em 2006. Infelizmente não [estou trabalhando na área]. Não [fiz nenhum outro curso após a formatura]. [Minha família] Me apoiou e eu não tive problema na decisão de fazer enfermagem. Tudo começou com um enfermeiro que cuidava da patroa da minha mãe, que é doméstica. Aí o enfermeiro cuidava do senhor para qual ela trabalhava e aí ele foi me explicando da profissão e eu me interessei porque eu já trabalhava nesse negocio do cuidar, porque eu já fui monitor por uma instituição de caridade e, além disso, instrutor de informática. Então eu sempre estava ali perto, eu sempre cuidava de criança e essas coisas, e aí eu gostei da profissão pelo que ele falou e o aspecto financeiro me interessou bastante também. Aí eu optei pela profissão, eu não tinha nada em mente antes disso. E foi assim que eu me decidi.

Se for relacionado à etnia eu não senti nenhum preconceito não [na EEUSP], até porque na sala de aula eu sempre fui representativo assim, por participar de instituição dentro da faculdade, por representar a sala, nunca senti nenhum preconceito relacionado à etnia. Quanto à profissão, o preconceito foi pouco, mas dentro da faculdade mesmo a agente pode falar assim que uma boa parte dos professores pensa que a enfermagem é uma profissão exclusivamente feminina. Aí, na sala de aula, é muito comum você ouvir dizer "vocês enfermeira, futuras mães. Você tem que ficar quieto porque nós somos a minoria, ou algum alguns setores como Saúde da Mulher e Saúde da Criança, onde você chega no campo e o profissional da área ou o próprio docente chega e fala 'olha é meio complicado trabalhar aqui, ou aqui por causa dos profissionais aqui você não tem vez'. Então é uma coisa que eu senti, meio comum assim de acontecer. Até que criança nem tanto, porque de criança é uma coisa que eu até gosto, sou até paciente, gostam muito de mim, agora por parte dos profissionais e de alguns docentes isso acontece. Isso em relação à sexualidade. Então, conforme eu disse, nas áreas de estágio relacionadas, a área de Saúde da Mulher, que por sinal o movimento feminino ta muito forte.

[Preconceito no campo de estágio] Não. Pelo menos que eu tenha percebido não. Sempre, por sinal, fui muito respeitado, até porque, assim, todo lugar que eu cheguei para fazer estágio, essas coisas, eu procurei sempre me impor, saber fazer, 
assim, essas coisas. E assim, a gente pode perceber preconceito, em relação ao aluno, em você ser aluno em relação ao paciente, mas ainda assim é muito, muito raramente. É muito raro isso, porque geralmente me deram, um voto de confiança no procedimento e no que eu tinha que fazer.

Bom, o que é um pouco complicado [no mercado de trabalho] é que alguns hospitais têm alguma preferência pelas etnias fundadoras dos hospitais, imagino eu. Então se for, eu imagino que o hospital que seja judeu, alemão, ou sei lá qual for, talvez dêem preferência pra quem tenha conhecimento desta cultura. Até aí, se existisse um hospital afro-brasileiro, eles também dariam preferência pra gente, então eu até concordo. Eu acho que agora a dificuldade fica maior, assim, na hora de procurar emprego que me chama a atenção é que, se você for para pra pensar, você está em igualdade com outra pessoa, eu nunca ouvi falar de preconceito de branco, agora, assim, pelo que geralmente os diretores, quem vão ser geralmente os brancos. Agora que eu te digo se for parar para pensar nisso, é melhor nem sair de casa e procurar emprego, se for pensar nisso, eu prefiro não pensar nisso, deixar de lado. E como eu tive um problema de preconceito no serviço que tive durante a graduação, então eu prefiro não pensar nisso.

Bom, o que acontece é que é um processo histórico [com relação aos poucos negros na sala de aula] porque desde que chegou ao Brasil na forma de escravo e tal, não houve espaço ali para o crescimento do negro na sociedade e foi libertado abriram as cancelas e se virem. Aí fica complicado porque se essas pessoas não tiveram um estudo adequado pra elas conseguirem se colocar na sociedade, vão seguindo, e os filhos vão se seguindo por esse processo e ficam as dificuldades, de começar a trabalhar cedo porque não cabem numa mão o numero de pessoas que trabalham na sala de aula, durante a graduação, mas, é necessário o esforço para chegar em algum lugar, uma vez que meus pais não poderiam me sustentar na graduação, coisas que outros pais puderam, mas porque, os meus avós tiveram o ensino primário. Meus pais se formaram no ensino médio, e eu e a minha irmã estamos no mesmo ano e no ensino superior. Espero eu que eu possa ir mais longe e que meus filhos possam entrar no mestrado, seja lá o que for, mas isso, isso tem um peso muito superior. A gente não tem aquela condição de levar o estudo mais longe ali pros filhos, então o que vai acontecer é que seus filhos têm que entrar mais cedo 
no mercado de trabalho, estudar em detrimento da possibilidade de ensino que pode receber, mas entre pescadas de sono na sala de aula, mas foi possível chegar até aqui e a tendência, pelo menos na minha família, é que a gente tem conseguido o crescimento. Os dois se formaram na USP, por sinal, e tem esse fator agravante, eu acho que o fator agravante está bem por ai. Então tem que ter condições, mas também parte do próprio negro correr atrás disso. Então eu fiz isso e eu sei de outras pessoas que se formaram na USP e vieram de uma situação bem mais complicada que a minha. Então cabe a própria categoria, a própria etnia procurar o seu reconhecimento e ir atrás das coisas também, porque não adianta lamentar só que eu nasci negro e sou coitado por causa disso, porque eu falei que eu que nunca passei pela situação de preconceito, mas, porque, então porque no serviço que eu trabalhei era professor, cargo de destaque, fui diretor, quem é que vai desobedecer uma pessoa que esta num cargo superior dessa forma? Dentro da universidade eu fui aprovado no vestibular e quando você chega na instituição você tem uma certa autonomia e o respeito que você ganha com a faculdade, então quando você chega em algum lugar de branco é porque você é o cara! Então, por isso que simplesmente a questão de preconceito, eles tratam mal o outro é porque vê que você está mal vestido e não tem posição. Quando você aparece de branco você é o doutor. Fui trezentas vezes chamado de doutor e senhor, então to cansado de ser chamado, inclusive até por pessoas mais velhas, por causa da posição social que você atingiu. E eu acho que não seria necessário isso para você ganhar respeito, mas infelizmente a nossa sociedade vive em torno desses valores e isso acaba me embranquecendo.

[O fato de ter trabalhado durante a graduação] prejudicou porque, pode perguntar para qualquer docente aí, assim, eu acho que eu pude aprender, mas eu poderia ter aprendido bem mais se eu não tivesse trabalhando porque você falta, você chega atrasado, você tem sono, você chega cansado, tem a questão de você ter uma jornada integral, de estágio, aula e ainda tem uma questão de você ter uma terceira, quarta vida aí. E o estágio, e a aula, o serviço, e você tem a sua função como filho dentro de casa, então você fica 24 horas. Então dos quatro anos, foi três anos dormindo quatro, cinco horas por noite e eu sei que se eu tivesse que fazer isso, eu faria tudo de novo, mas foram diversas festas que eu não pude ir, os passeios, mas isso é o de menos. Mas o que me complica mais é que eu acho que eu poderia ter aprendido mais. Eu espero que isso não me faça falta mais tarde. 
A minha irmã, se formou em letras e atualmente trabalha como revisora em uma editora de revistas daqui de São Paulo e do Rio de Janeiro.

Bom, [fui chamado de doutor] porque não é a uma questão de respeito pelo professor, por mais que seja uma categoria que esteja defasando atualmente, eu respeito, por que acreditasse que ele é o provedor do conhecimento. Então, a partir disso todo mundo tem um certo respeito, apesar de você ter o poder da bronca, da advertência de mandar cartinha por pai, destas coisas, eu nunca apelei pra isso, eu sempre consegui ser respeitado antes, e é uma coisa que eu acho até estranha porque todo mundo reclama da juventude de hoje em dia. O vestir de branco é evidente, é bem próximo da profissão e o estar andando pela rua, é bem fácil porque, é só você observar. O shopping é o símbolo, em geral, na cidade moderna contemporânea, você tá dentro do shopping, se você ta de bermuda de chinelo, nem precisa ta de chinelo, pode ser de tênis e de bermuda, você pode até estar arrumadinho, aí logo que você entra numa loja ficam do teu lado e vão perguntar o que você quer ali e vão ficar ali parado. Agora se eu entro e eu tô de branco ou eu to de social, que são meus trajes de serviço, logo eles vêm e vão dizendo: 'Pois não, o que o senhor quer? O que o senhor deseja? Nós temos isso, aquilo'. Você percebe fácil isso. E assim, uma coisa muito evidente também é se estou passeando com algum primo meu, pronto, é gangue. Mas se eu estou passeando com a minha namorada, que não é uma questão de preconceito nem nada, mas ela é branca e loira, aí o tratamento muda mais ainda, porque além de eu mostrar o status pela roupa, ainda pensam que com certeza eu tenho dinheiro, porque o que oferecem de roupa, pensam que ou eu sou jogador, ou que sou pagodeiro. Alguma coisa passa pela cabeça, mas é muito diferente de eu andar sozinho, ou eu andar com um parente, andar com uma roupa de serviço, ou andar com a namorada então é o clímax, fiquei altamente superior. Com certeza [isso é uma forma de preconceito]. Eu acho que eu deveria ser tratado a "pão de ló" da mesma forma, de bermuda e camiseta, da mesma forma que eu sou tratado a "pão de ló" quando eu to com a minha namorada do lado.

Eu acho que foi bastante interessante essa pesquisa, assim, eu espero que eu não seja assim que pessoas que estão interessadas nesse trabalho, que não sejam as últimas e que eu não seja parte de uma minoria. E, assim, tentando fazer minha parte que eu acho que é tentando passar isso para os meus descendentes, que é tentar o 
crescimento e, independente do preço que ele tenha, ir a adiante e que isso possa acontecer com todos os meus irmãos indiretos aí. E é isso.

\section{Colaboradora 10}

Eu me considero negra pelo fato de que meu pai, meus avós eram africanos, da África mesmo, meu pai. Meu avô era de Angola e a minha avó era portuguesa. Ai eles acabaram vindo aqui pro Brasil em torno de mil oitocentos e pouco, ai eles se conheceram aqui, mas não aqui em São Paulo, eles foram pra região norte, daí eles trabalharam na lavoura e tudo. Meu avô segundo eu não cheguei a conhecê-lo, mas, meu pai falava que ele chegou a morar no Quilombo dos Palmares. Ele não chegou a ser escravo, meu bisavô chegou a ser escravo, meu bisavô veio como escravo e a minha bisavó não era escrava, era portuguesa. Pelo que falam ela era dona de um pedaço [de terra] na região próximo ao Ceará. Ela era filha de um fazendeiro daquela região próxima de Pernambuco, daquela região.

Então, daí, meu pai que era aquele negrão enorme e tudo, minha avó também, mas ai minha avó já era, acredito eu que eles devam ter separado, os dois. Imagina, que em mil oitocentos e pouco eles iam permitir que a sinhazinha iria ter alguma coisa com escravo e ia ficar tudo numa boa. Eles devem ter separado os dois. Ele deve ter ido pro tronco, deve ter morrido. Isso meu pai não conta detalhes. Minhas tias assim, elas acham que essa parte é um parte muito ruim da vida. Então, daí elas não, simplesmente, elas ignoram. Ai meu pai que já nasceu na região de Curitiba, na região de Minas meu pai nasceu. Mas também ele veio de, a minha avó já era alforriada, tudo, já morava aqui no Brasil, então, meu pai já nasceu aqui no Brasil em 1921, então, eles já moravam na região de Minas, mas ele trabalhava assim, na roça e tudo. Ai, depois de algum tempo, ele saiu de Minas e veio aqui pra São Paulo pra trabalhar no Banco da Amazônia, mas não pra trabalhar no Banco da Amazônia, porque tinha toda aquela parte de borracha e tudo, cultivo da borracha. Então, o Banco da Amazônia era responsável pelo transporte e a guarda dessa borracha até que fosse pra manufatura de pneus, desses negócios. Então, daí como o meu pai trabalhava em Minas e trabalhava pra uma gerente de produção, não sei bem como é 
que era o negócio. Ele chamou o meu pai que ele viesse pra cá, pra São Paulo, porque eles estavam abrindo um armazém aqui em São Paulo, que viria borracha de Manaus até Santos, até o Porto de Santos e de Santos iria ficar num armazém e meu pai iria ficar tomando conta desse armazém. Ai, nesse meio de tempo, ele conheceu a minha mãe, casaram, a gente morava ali do lado da Vila Prudente.

Meu pai morreu, eu tinha 10 anos, então eu não cheguei a pegar assim muita, ai ele foi, eles estavam no quilombo e eles vieram pra Minas pra poder ajudar na fazenda de pessoas lá em Minas. Daí, de Minas que o meu pai acabou vindo pra São Paulo. Ele conheceu a minha mãe aqui em São Paulo. Então ele morou um tempo no quilombo, foi pra Minas como trabalhador na roça e tudo, mas foi. Daí, aqui em São Paulo, ele trabalhava pelo Banco da Amazônia, mas na parte de armazém de guardar borracha.

Minha avó, eu não conheci, minha avó eu a conheci, mas assim, ela era assim, aquela senhora, aqueles negócios de velha. Enorme, gordona, mas assim, ela sempre morou no sítio, na fazenda, nunca morou aqui na cidade nem nada, daí ela, como eles moravam em Minas, depois que nós estávamos aqui em São Paulo, eu nasci aqui em São Paulo, mas meu pai sempre ia para Minas e voltava. Então, daí, foi quando, eu era gêmea com a minha irmã, só que a minha irmã morreu quando nasceu, de parto normal, mas prematuro. A minha irmã morreu aqui mesmo em São Paulo, no hospital Matarazzo, sendo que a minha mãe estava saindo daqui de São Paulo pra ir pra Minas, foi quando arrebentou a bolsa, aí nascemos aqui. Então, como era prematura eu tinha que ficar aqui mais tempo. Porque naquele tempo, em 1950, não tinha nada. Não tinha condições praticamente nenhuma e, naquele tempo, já sobrevivia com um quilo e seiscentos. Diz meu pai que a minha irmã era enorme, gordona, tinha três quilos e tanto e tinha eu que era aquele rato, horroroso, feio. Ai na hora que ele foi registrar a gente ele disse: "Não, a que era bonitona morreu, então, põe um nome bem feio nessa daí, porque essa também vai morrer. Pra quê que vai colocar um nome todo sofisticado? Essa aí não tenha dúvida, vai morrer também". $\mathrm{Ai}$, nesse meio de tempo, depois que a gente ficou maior, que tinha uns 5 anos mais ou menos, nós fomos pro Rio, nós fomos morar no Rio porque a minha avó começou a passar mal, ela já tava com muita idade e, em Minas, não tinha recurso. Minha mãe precisava trabalhar, meu pai ganhava pouco, então, ela falou assim: “Pra mim ir pra 
Minas, eu vou ter que ir morar numa fazenda e como é que eu vou tomar conta da sua mãe numa fazenda? Tomar conta dos meninos e, além de tudo, ter que trabalhar? Então, é melhor eu ir pro Rio, porque eu tenho melhores condições de trabalho". Então a minha mãe foi como empregada doméstica mesmo. Então ela foi pro Rio e minha avó veio de Minas pra Niterói. Então, até que ela se adaptou bem, porque naquele tempo Niterói era assim, um ovo, mas a gente morava perto da colônia dos pescadores e tudo, então ela se adaptou bem. Até que depois que o meu pai morreu, ela passou a morar praticamente junto com a gente, ela sobreviveu. Ela morreu faz uns 10 anos mais ou menos, ela viveu bastante. E daí ela ficou muito confusa, muito desorientada, daí veio a minha tia pra morar com a gente, pra morar com ela também. Depois assim, eu precisei colocar ela num asilo em Teresópolis, daí porque eu não podia ficar lá, eu queria fazer enfermagem e eu não queria fazer lá no Rio, porque o Rio sempre foi assim, lá, é um lugar muito bonito pra você passear, mas, em condições de saúde, esse tipo de coisa, sempre foi muito ruim.

Lá, sempre o povo foi muito mais tranqüilo, enquanto a gente se preocupa em ficar trabalhando eles não. É carnaval? Então, todo mundo saía. Eu trabalhei lá no Rio um pouco como atendente de enfermagem, mas foi assim, 2 anos que eu trabalhei lá que eu me desesperei, porque na época de carnaval todo mundo saía. Saía assim, metade do hospital e você ficava. Naquele tempo, chegava atendente dava medicação, fazia de tudo. Então, você ficava com três, quatro andares. Então, a gente ficava esperando os distintos que tinham ido pro carnaval voltar pra poder continuar a dar o plantão. Enquanto isso, você ia dando medicação, acudindo um, acudindo outro. Daí eu falei assim: "Não, não é isso que eu quero. Eu quero aprender a enfermagem e que realmente eu faça jus aquilo. Que eu to acudindo, que eu to cuidando dos pacientes pro bem e não assim desse jeito”. Ai então foi por isso que eu peguei e falei: "Não, eu vou embora pra São Paulo, eu vou embora pra São Paulo, eu vou entrar na escola de enfermagem e eu vou estudar na USP, porque eu não tenho condições de estar pagando escola, eu preciso ir trabalhar". Ai ela falou assim: "É que a USP é período integral. Como é que você vai fazer?” Eu peguei e falei assim: “Ah, eu dou um jeito!”. Daí eu trabalhei 2 anos antes, guardava tudo, tudo, tudo, tudo o que recebia pra poder, porque a minha idéia já era entrar na USP e fazer a USP. 
A minha avó materna a gente praticamente não tem conhecimento nenhum porque a minha mãe foi adotada por uma família do norte do Rio, norte do Estado do Rio. Parece que ela foi adotada pelos padrinhos e não sei o quê, então, ela foi uma pessoa muito lutadora, mas assim, não se tem nada de verídico do que foi realmente a vida dela antes. E nem por os antecedentes dela. Ela [minha mãe] já tinha morado no Rio um período e depois ela queria vir pra São Paulo, queria trabalhar em São Paulo e essa família permitiu que ela saísse, ela já tinha completado 21 anos, eles permitiram que ela saísse de lá e viesse pra cá. Ela falou assim: "Não, eu vou voltar pro Rio, por que no Rio, pelo menos eu sei por onde começar".Ir até eles e começar a trabalhar. Meu pai faleceu, eu tava com 10 anos, eu era gêmea e depois a minha mãe não conseguiu engravidar mais.

Eu sou da raça negra, negra mesmo. Pra mim, eu não considero preconceito e nem eu considero, pra mim é indiferente, sabe? Pra mim, se chamar de negra, ou se chamar de afrodescendente ou me chamar de preta, pra mim, é indiferente. Agora, uma coisa que eu acho que não deveria de haver é essa discriminação em você dar cotas porque ele é negro. Isso eu discordo. Eu discordo porque tanto o negro quanto o branco, todos podem ter a mesma possibilidade de estudo. Você tem, talvez, não a mesma oportunidade. Se você tem um pai, uma mãe que preze que você seja, que você tenha uma condição de vida melhor do que a deles, então, você vai entrar numa escola. Eu sempre estudei em escola pública, eu sempre estudei em escola pública desde o primário, fui e fiz até o fim e não me arrependo. Minha filha estudou em colégio particular e agora ela ta na faculdade, ta na XXX, mas não porque, quando eu a tive, não que eu não tinha condições, eu queria botá-la no parquinho, só que o parquinho só pegava com 3 anos. Ela não se adaptou a creche do HX, porque a creche do HX agora ta aqui no prédio dos ambulatórios, na parte de baixo e tudo. Antes, a creche do HX era, mas era mais pra lá um pouco e tinha tipo, era um sistema de refrigeração, que, como tinha a lavanderia ali dentro tem um verdadeiro forninho. Na hora que você tirava as crianças de lá era um 'Deus nos acuda', porque São Paulo era, agora que São Paulo ta dando 4 temperaturas assim, mas antes, isso aqui era assim, 6 horas da manhã, era aquele frio, frio, frio, frio, uma coisa, daí por volta de onze e meia, meio dia, dava aquele sol. Quatro e meia, cinco horas ele estava saindo, já estava caindo a temperatura, dependendo de onde você morava. Eu chegava em casa já a noite, não com o frio que você tava de manhã, mas um frio úmido, uma 
garoa. Então, uma criança que fica 8 horas da vida dentro de um ambiente quentinho forninho e coisa, ai você sai no vento e coisa, olha, foi um 'Deus nos acuda'. Enfim, essa criança começou com crise de bronquite, com febre, com isso, com aquilo e com aquilo outro e não conseguimos fazer com que resolvesse. Minha mãe veio do Rio, ficou aqui em casa pra poder tomar conta dela porque não tinha outra solução. Porque eu não tinha condições de funcionária. De ta pagando uma creche a altura, porque sempre teve creches ótimas e esse tipo de coisa aqui em São Paulo, só que, essas creches cobravam um dinheiro muito grande e não dava, na realidade não dava, porque essas creches demandavam um dinheiro muito grande e não dava, na realidade, não dava. Aqui no HX a gente ganhava 200 cruzeiros, esse era o ordenado da gente no comecinho. Então, como que ia dar, pagando apartamento e tudo, não tinha jeito. Então eu falei assim: "Não mãe, a senhora vem aqui pra São Paulo, fica com ela e a gente vai dando um jeito".

Então, eu acho que foi um erro muito grande, eu acho que foi assim, um menosprezo que se "auto deram" em dizer assim: "Não, nós somos uns coitadinhos, nós precisamos ter uma cota, porque se nós não tivermos uma cota, nós não vamos conseguir entrar numa USP, conseguir entrar em qualquer Universidade que seja”. E só que por uma infelicidade teve um erro muito assim dos governantes então, passou essa determinação, mas, eu discordo. Discordo mesmo. Eu acho que foi um retrocesso, foi a mesma coisa que você falar assim: "Vocês são incapazes, só que nós estamos dando pra vocês uma oportunidade de vocês, não precisa nem estudar muito vocês vão passar, vocês têm esse número de cotas". Assim como essas leis de diretrizes e bases que vai passando os meninos conforme Deus assim o permite, então eu vou chegar na oitava série, eu mal sei escrever o "c", a casa, capaz de ainda botar com "z" ainda, então, isso também é outra coisa. Que seria muito melhor se você visse, avaliasse, ou: "Você não tem condições de passar porque você ta ruim, isso, isso, isso e isso, então você estuda, então você vai ter as condições". Porque nisso, você também estaria dando uma lição de cidadania pra esse indivíduo, porque na medida que você facilita: "Imagina, porque que eu vou ficar me preocupando durante o curso?" Aqui em São Paulo nem deu pra eu perceber muito, porque eu to mais pra lá do que aqui, ai não deu nem muito pra perceber, mas, lá no Rio, é uma pouca vergonha. Porque o pessoal vai e: "Não, nós temos direito, nós entramos na cota, e nós vamos fazer e nós entramos na Universidade”. Então, daí o que você gera 
disso? Mais conflito ainda. Cada vez que você vai gerando mais conflito, cada vez você vai piorando a situação. Eu acho que isso, além de não valorizar a pessoa, porque daí ela vai ficar com aquele estigma: "Entrei porque sou negra, se eu não fosse negra, eu não teria entrado". Então, eu acho que isso foi uma bobagem, uma bobagem muito grande.

[Entrei na EEUSP] Era o processo que você fazia, toda área de saúde, porque era CECEM, CEFEIA e MAPOFEI. A CECEM era pra área de saúde, então era medicina. Porque sempre tinha muito pouca 'fisio', praticamente não tinha, mas era medicina e enfermagem, daí o CECEM e o CEFEIA era pra área de humanas e o MAPOFEI era pra área de exatas. Era o vestibular como hoje é o da Fuvest. Então você vinha, você fazia a inscrição, e você não tinha nada de prova na metade do segundo grau, você ia ler livro, ENEM, não tinha nada disso. Nós tínhamos ainda, no primeiro ginasial, nós tínhamos latim além de tudo e eu me sentia ainda prejudicada porque a enfermagem fazia a mesma prova da medicina, só a pontuação que era diferente. E o pessoal da medicina fazia o que o segundo grau era o científico e eu tinha feito escola normal, então, a matemática, química, física e tudo, eu não tinha tido a base que o pessoal tinha. Então foi quando eu acabei a escola normal, daí no ano seguinte eu falei assim: "Eu não vou ser professora!” Eu fiz a especialização pra pré-primário, eu fiz lá no CC, na Praça da República, fiz tudo, só que eu falei assim: "Eu não vou ser professora, eu quero ser enfermeira. Então, eu vou fazer esse ano agora que entra. Eu vou trabalhar, eu vou fazer um cursinho!" Eu ainda fiz biomédicas, acho que artes médicas era aqui na Consolação, porque o X, já naquele tempo existia o X, estava começando, mas era assim, muito caro, muito caro, assim muito, muito, muito, uma coisa assim. Então eu fui pra esse ai, que era assim, alguns professores dissidentes do X, então, daí a gente tinha aula e tudo. Então, eu trabalhava durante o dia no escritório, como auxiliar de escritório e eu fazia o cursinho toda noite.

O meu pai era analfabeto e a minha mãe mal sabe ler e escrever. Minha mãe foi empregada doméstica até o tempo que eu entrei aqui no HX ela era empregada doméstica e o meu pai, não é porque ele trabalhava no banco estivador, porque pra mim, aquilo lá era estivador. Ele só não coletava borracha, mas ele pegava aqueles negócios de borracha, aqueles 'farpos', aqueles negócio, pra pode estar mandando 
pra Pirelli hoje, pras outras, pra fazer pneu, porque e borracha era matéria-prima pra poder ta fazendo. No entanto, eu sou radicalmente contra isso [cotas], porque eu acho que as pessoas têm oportunidade pra se estudar, não se estuda porque não quer. E muitas das vezes você tem oportunidade, só que você tem o meio ambiente faz com que você mude, faz com que você perca aquele seu objetivo principal. Então, daí, é muito mais fácil hoje você pegar que fala assim: “Olha, vamos lá que hoje eu te dou cigarro, te dou Coca Cola, eu te dou lanche, tudo, não sei o quê, não sei o quê, não sei o quê". Pra que você vai? Amanhã você vai ter que trabalhar pra poder ter, pra você comprar, sua Coca Cola, comprar seu lanche ou isso ou aquilo outro que o valia. Ou então, uma turminha vira assim e fala: "Não, vamos lá que eu te levo de carro". Porque que eu vou querer tomar o metrô, apinhado de gente e tomar o ônibus apinhado de gente, ficar em pé e levar? Eu vou querer uma carona que é muito mais. O próprio modismo, a própria condição de vida, faz com que distorça o norte que as pessoas poderiam estar tomando. Então, eu acho que, por esse motivo, não deveria de dar cota. Deveria ter a mesma oportunidade, então, todos tendo a mesma oportunidade vai fazer com que eu tenha que estudar hoje. Meninos de 8 anos: 'eu tenho que estudar por quê? Se eu quero ser um engenheiro amanhã eu vou ter que competir com quem ta estudando numa escola particular, isso, daquilo, daquilo outro. Outro menino que ele tem uma vida, que ele tem carro, que ele tem empregada e coisa. E eu, sou filho de uma empregada, então, eu tenho que ter isso na cabeça. Agora, do jeito que tá hoje, o que você mostra pra esses meninos? Muita calma nessa hora! Amanhã você não precisa, você já vai entrar com um pouquinho de pontos, então, você já não precisa se preocupar tanto.

Eu acho que não [devem ser cotas sociais], porque se fosse assim você teria que estar pegando todos os pobres. Porque você não tem só negros ali na favela. Você tem o branquinho também que ta ali na favela e que também ele quer ser um engenheiro, no entanto, ele não vai ter condições porque ele não tem a cor. Então, nessas alturas, nós estamos criando uma outra desigualdade que talvez seja pior. Eu acho, porque você vai ter um pobre, um menino que mora ai em Paraisópolis que é branco, a origem dele é branca e você tem em Paraisópolis um menino que é negro. Esse menino que é negro, ele ganhou a cota, ele entrou na USP, ele estudou em escola pública em tudo e coisa. Esse branquinho, também fez escola pública e tudo, só que esse branquinho, que também é pobre, tão pobre quanto este outro, que ali, eu 
não vejo quem seja mais rico ali, morando na mesma favela, só que esse branquinho, deixa eu falar com sinceridade, dificilmente ele vai conseguir entrar na USP, ele não vai conseguir porque, se a gente partir do princípio de que, estão privilegiando quem é negro, então, ele vai ta tendo que concorrer com o menino que fez Mackenzie, ele vai ter que concorrer com o menino que fez o Mario Cabrini e tudo porque ele é branco! E por quê? Então, eu não dou nada pra ninguém e todos lutem pra se conseguir alguma coisa.

É isso que pelo menos a mim me preocupa, será que todos esses cotistas eles chegaram a terminar essa faculdade que começaram? Agora, em terminado, se eles fizeram uma área, se eles fizerem enfermagem, eles podem ser um empregado, agora, se eles fizeram, outra área, até medicina, ou qualquer outra coisa, eles vão ter condições de estar montando um consultório? O fato de ser cotista e 'eu não vou no seu consultório ou coisa que o valia'. Isso daí eu nem muito me preocupei, nem muito pensei pelo fato de que é uma coisa tão rara, de conseguir chegar a terminar aquela faculdade. Ele vai ser merecedor, buscar das coisas que ele conseguiu, os méritos que ele teve perante aquilo que ele fez, então, ir no consultório de um alemão, ou ir no consultório de um negro, pouco importa, pra mim, o que importa é que ele fez uma escola, ele estudou, ele se formou e ele dá de si o melhor do que aquilo que ele possa dar. Agora, eu não aceito que muitos sejam: "Não, eu fiz USP!" E eu sou o pior funcionário que possa existir e, no entanto: "Eu fiz USP, eu sou a elite". Mas assim, as condições de vida são muito complicadas.

Eu me formei em 73. E eu fiz vários cursos livres. Eu fiz auditoria, não cheguei a fazer mestrado, não cheguei a fazer doutorado porque eu sempre trabalhei na área de assistência, então eu sempre fiz cursos relacionados à sociedade. Eu sempre trabalhei dentro de UTI e amo o que eu sempre fiz.

Minha mãe sempre foi uma pessoa assim muito liberal "Você faça aquilo que você melhor achar". Ela sempre falou assim: "Eu gostaria que você fosse professora porque você teria sábado, domingo, feriado, férias pelo menos 2 vezes por ano, na hora certa você tava de férias. Já que você ta fazendo enfermagem, você não vai ter que ter ciência que você vai trabalhar sábado, domingo, feriado, de noite e tudo". Eu falei assim: "Eu, seu disso!”. "Não, tudo bem, quem vai trabalhar é você, quem vai resolver a tua vida, tua vida é sua, você que tem que ver o que você quer". Era uma 
coisa assim que eu já, eu tinha 16 quando eu acabei a escola normal. Eu poderia ter permanecido, no entanto, eu conheci uma das patroas que a minha mãe teve, ela foi a doutora AA, eu achava assim. Ela vinha dos Estados Unidos, muitas vezes eu ia pra casa dela lá aonde a minha mãe trabalhava. A minha casa era muito longe ai eu dormia na casa aonde ela trabalhava e, muitas das vezes, a doutora AA tava chegando dos Estados Unidos, Inglaterra e tudo e ela falava assim pra mim: "Olha..." Ela chegava assim toda de branco, toda de uniforme ai ela falava assim: "Ta vendo esse uniforme? A sua mãe vai lavar, engomar porque amanhã eu tenho que ir pro hospital". Eu falava assim: "Nossa, muito bonita a profissão da senhora". Ai ela falou assim: "É, é muito bonita, é muito trabalhosa, mas é muito bonita". Então, eu conheci uma enfermeira, mas não na atividade e eu não fui uma pessoa assim doente, nem tinha contato com hospital nem nada, só de pequenininha.

Quando eu decidi fazer enfermagem, eu trabalhava como auxiliar de escritório, pelo seguinte, porque eu não podia trabalhar em hospital porque eu era menor. Eu tinha 16 pra 17 anos. Só podia trabalhar no hospital quem tivesse 21, então, eu não podia. Então, mesmo eu trabalhando como atendente, ai eu trabalhei como atendente na Santa Casa, mas aí acho que foi em 69, 70, daí eu já tava com 19 anos, daí a irmã deixou, mas foi o quê? Eu trabalhava de noite e a fiscalização não ia até lá porque se não, também não ia poder. A fiscalização, era a fiscalização da farmácia, quer queira, quer não, eles alegavam que a gente poderia estar encaminhando pra vício, drogas, porque as drogas sempre houve. Dolantina, morfina, essas coisas. Então, por isso que eles não deixavam quem tivesse menos de 21 anos ta manipulando drogas. E, naquele tempo, enfermagem era, potencialmente, os atendentes.

Enquanto estudante de enfermagem, eu trabalhava aqui na $\mathrm{X}$. Em cada férias eu ia pra Praia Grande, eu ia pra olhar criança, eu ia trabalhar com 'recreacionista'. E, só no último ano, quando eu tava fazendo Saúde Pública, que eu trabalhei num hospital. Daí também foi como atendente de enfermagem, eu trabalhei num hospital aí na Lapa, que era um verdadeiro, um necrotério humano! Nossa, era terrível! Terrível, terrível! A judiação que faziam com as crianças. E a primeira denúncia que eu fiz, eu fiz enquanto atendente, trabalhando a noite, hoje no INSS, naquele tempo era o SUS, porque era uma coisa assim, terrível. As crianças, você botava aquelas 
crianças tudo assim em cima de uma mesa, hidratava com soro, todo mundo ali, você tinha que ver quem fazia xixi, só que, o primeiro a fazer xixi, molhava a fralda do outro, do outro, do outro, só Deus sabe. Era muito triste aqueles adultos maltratados, como era difícil. Daí, quando eu acabei, eu já prestei concurso no HX, entrei, eu tinha que fazer a escola novamente, eu fiz. Daí, quando eu acabei, mas, daí eu já fazia, sábado e domingo eu ficava no hospital pra poder acabar de pagar as horas da semana, porque naquele tempo a gente fazia 48 horas. Aqui, eu trabalhava com, foi tanto que surgiu todo o pessoal, todos os professores deveriam receber tese, mas ninguém tinha tese. Só quem tinha tese era a doutora VAH, era a única que tinha tese, então, como todos teriam que estar saindo com a as suas teses eu não tinha gente pra datilografar, porque naquele tempo não tinha computador. Então tinha que datilografar, aí eu datilografava as teses do pessoal. Daí eu pagava o valor, porque a gente tinha uma cota mínima, um valor mínimo pra poder a gente ficar aqui. E, ao mesmo tempo eu limpava a casa, a gente tinha almoço, tinha janta, tudo, mesmo assim eu tinha que me deslocar e tudo.

Olha, por parte de casa não [senti preconceito racial] e por parte dos coleguinhas, que naquele tempo a gente tinha, eu acho, que nem tanto porque todo mundo era, a gente estudava em colégio público, aí todo mundo tava no terceiro, no colégio normal, todo mundo chegava com a intenção de ir trabalhar. Não tinha ninguém assim que tivesse com a intenção se ser uma donzela. Então, quando eu falei que eu não ia ser professora, que eu iria ta estudando, que eu queria fazer uma faculdade, a própria secretária lá da escola, do FD, falou: "Nossa, que bom”. Então eu falei assim: "Não, eu vou fazer enfermagem, eu vou fazer". Daí, aquele ano eu trabalhei como auxiliar de escritório, daí o outro ano também. Trabalhei 3 anos, só que no terceiro ano, no segundo ano eu fiz cursinho e, no final do segundo ano, eu entrei aqui. Daí eu trabalhei até o mês de fevereiro, ainda quando eu pedi demissão, porque eu trabalhava na Kodak, ai o meu chefe falou assim: "Porque que você vai fazer enfermagem e não prestou bioquímica? Porque você já ta dentro do ramo, porque a Kodak vai mudar lá pro Morumbi”. Eu falei: "Não, eu quero fazer enfermagem".

Não, eu acho que não [senti preconceito racial na EEUSP]. Porque, naquele tempo, você tinha a doutora $\mathrm{N}$ que era negra, você tinha, aquela já morreu, você tinha 
a N. Na minha turma eu tinha $\mathrm{D}$ e tinha mais outra, uma outra menina que eu esqueci o nome dela que ela era de uma turma anterior a nossa. Acho que era $\mathrm{C}$ o nome dela, esqueci o nome dela. Ela era bem assim 'fortona'. E, ao mesmo tempo, nós tínhamos aqui na USP, nós tínhamos muitos funcionários negros, então, parece assim, que eles tinham cá comigo, como se fosse assim, um filho que tinha saído de casa e que tava morando aqui. Então, aonde eu ia eles ficavam muito ansiosos, porque eu também sempre fui muito chata pra comer, então, eles falavam: "Não, você tem que comer, você vai pra Cidade Universitária, tem que comer ovo de manhã, tem que comer isso, que não sei o quê." O pessoal, de um modo geral, se preocupava muito, pelo menos, eu sentia, que se preocupavam muito comigo.

Morei [dentro da EE]. Eu morava no terceiro andar e o meu quarto era o segundo de lá pra cá, era o 215 se não me engano, o número do meu quarto. De noite a gente fazia pipoca, muito contra as vontades da Dona MR, nossa, era um barato. No final do segundo ano começou a desativação porque eles queriam aumentar as salas de aula e o refeitório pros professores. Daí, eles reformaram lá em cima no terceiro andar, eles fizeram aquela sala grande lá do fundo, ai eles fizeram aquela sala grande. Eu já tava morando aqui em São Paulo e ficava morando aqui mais por conveniência e na nossa turma tinha bastante gente que ficava morando aqui e morava aqui em São Paulo, então daí, deixaram somente pro pessoal que era de fora. Daí ficou só assim uma ou outra, daí depois no terceiro ano o pessoal, ai já mudou mesmo, ai foi morar no apartamento e tudo.

A escola não dava nenhuma bolsa nem nada. À medida que eu datilografava a tese pras professoras, a gente pagava, a gente tinha que pagar um determinado valor, era um valor mínimo, que a gente pagava não por causa de comida, era pra poder tirar xerox, mimeógrafo, essas coisas. Então, a gente pagava tipo assim 20 cruzeiros, uma coisa assim, mínima que a gente pagava. Daí quando passou não ter a residência, nós precisávamos pagar a alimentação, daí como nós precisávamos pagar a alimentação, que também era um valor muito menor do que era aqui na redondeza, mas a gente podia ta tomando café aqui e almoçando, jantando, só que a janta era cinco e meia da tarde. Aqui, acho que era até seis e meia ou quinze pras sete se não me engano, porque as 7 fechava. 
Não [eles não davam ajuda financeira], eles partiram assim do princípio que eles deram quase 6 meses. Eles avisaram tipo, na metade do ano que, a partir do outro ano, só ia ficar assim aquele que estritamente não morava realmente aqui em São Paulo. Que realmente não morava aqui em São Paulo. Então, eu lembro que ficou a A, tinha as pessoas dos outros anos também, tinha, tinha dos outros anos também. Que, muitas das vezes, ela saia pra dar plantão, e voltava no outro dia, iam pro estágio e voltavam, sabe? A Ca, que hoje ela ta no $\mathrm{XXX}$, nem sei onde ta a $\mathrm{Ca}$ hoje, a Ca era minha vizinha.

[No começo da vida profissional] Eu fiz o concurso e, depois do concurso, eles me chamaram e eu comecei a trabalhar. Então, inclusive, logo no comecinho, eu não tinha 21 anos ainda. Então o doutor V, que era chefe do Pronto Socorro, eu entrei, me botaram no pronto socorro, daí disseram assim: "Vixi, essa menina não vai dar certo aqui não, ela é muito criança, ela não pode ficar aqui”. Justamente porque eu tinha que assinar no pronto socorro, eu tinha que assinar o pedido de entorpecentes, então, daí não podia. Me mandaram subir pro sexto andar onde tinha pediatria e clínica médica. Nós tínhamos acabado de formar, mas não tinha saído regulamentação, não tinha nada.

[Logo que eu me formei] foram criados os conselhos, ai começou a ter os registros. No meu diploma eu ainda tenho o carimbo da especialização da farmácia. Não [mudou nada no meu diploma depois da criação dos conselhos] Não, pra mim não. Quanto foi por volta dos anos 90 mais ou menos, eu sempre fui engajada, líder, participava bem desse tipo de coisa, ai me chamaram porque eu moro a uns 3 quarteirões do conselho de São Paulo. Daí então, falaram: "Você não quer vir ajudar aqui no COREN, porque a gente ta com uma série de problemas, com muito poucos funcionários e tudo, você não quer dar uma ajuda, ainda mais que você mora pertinho? Vir ajudar a preencher, fazer tudo e preencher as coisas”. Ai eu falei: “Ah, tudo bem, vamos lá!”. Ai eu fique, não trabalhando, porque no Conselho se você não era concursado, não é funcionário, você é conselheiro. Então, me botaram como conselheira e assim eu fiquei. Daí, quando começou o código de ética, daí eu fui para a comissão de ética pra poder estar avaliando vendo os problemas de enfermagem e tudo. Ai quando foi em 2001, a R me chamou e falou assim: “Oh, você não quer ir lá pro Conselho Federal? Porque a representante nossa daqui de São Paulo ela teve um 
desentendimento com o presidente e a gente precisa de ter um representante lá, você vai?" Ai, eu falei assim: "Eu preciso ver lá no HX como é que vai ficar porque tem que ir lá nas reuniões". Ai ela falou assim: “Não, a reunião lá é uma reunião por mês. Dois dias de reunião, no máximo 3 dias. Se você aceitar, eu mando o ofício e tudo pra poder estar resolvendo". Conclusão, fui. Quando chegou em 2005, o presidente que o Senhor GLT, assim como vários funcionários e vários conselheiros pertencentes dos outros conselhos, a Polícia Federal deu um cata e ta todo mundo preso, então, eu era a primeira secretária, eu tive que assumir a presidência do Conselho Federal. Eu tinha que assumir a presidência do Conselho Federal, sendo que a minha experiência administrativa era de uma unidade de trabalho, uma unidade com o paciente, e isso, eu falei e deixei muito bem claro no dia em que eu fui pra lá. Eu falei assim: "Eu entendo de enfermagem em UTI e em cardiologia, agora, eu não entendo da parte administrativa". "Não, pode deixar que a gente lhe ajuda". De 2005 eu cobri até 21 de abril de 2006. Eu assinei todos os cheques que vinha pra ser assinado. As coisas lá no Rio é muito atrapalhado, muito confuso, sabe? O pessoal não leva as coisas a sério. Agora, hoje, eu to pagando o ônus disso tudo porque que eu fui simplesmente, eu continuei a falcatrua e tudo que estava ocorrendo anteriormente, então, agora, eu tenho que estar respondendo por tudo isso. Por isso, que muitas das vezes você não me acha aqui em São Paulo, eu tenho que ir pro Rio porque eu tenho que ir pra reunião porque eu tenho que estar respondendo processo, tenho que estar respondendo isso, isso e isso. Então, foi uma experiência a qual eu não desejo ao meu pior inimigo. Porque, pra você ir para um Conselho, pra você ir para uma coisa assim, hoje, mais do que nunca, eu vejo que a pessoa precisa ter uma experiência anterior administrativa. Mas, não só administração assim de uma unidade e coisa que o valia. Você tem que ter uma noção, e uma noção muito boa de uma administração pública, na qual, eu nunca tive. Então, foi isso assim uma coisa que machuca muito, porque você vai pra uma coisa, sendo que você, praticamente, te impedem de dizer: "Não quero!". Porque todos falavam assim: "Não, imagina, você tem condições de ficar fazendo e você vai fazer e a gente vai lhe ajudar". Depois você vê que tudo aquilo era uma pontinha de um iceberg e que, abaixo de tudo era uma estrutura totalmente... Porque esse desgraçado roubou nós pobres, porque se eu discordo e ele tivesse roubado ricos eu não estaria dando honras e glórias. Só que ele me roubou, você talvez não porque você ainda não tem, você não trabalhava na área, 
mas dos atendentes, porque tudo $25 \%$ é do COFEN, qualquer taxa que você pague no COREN 25\% é direcionado pro COFEN, e daí, o que ele fez? Passou a mão nisso tudo, se enriqueceu ilicitamente. É acusado hoje de que ele é mandante de mais de 4 mortes e que hoje, acredite se puder, eu acredito que realmente ele tenha feito isso. Eu não acreditava, menina. Eu não acreditava! Assim como eu acreditava que a enfermagem é uma coisa muito bonita e que você tem tudo pra torná-la melhor e cada vez mais científica possível, e eu acredito nisso piamente, mas eu discordo do roubo, do matar, do fazer.

Então, eu ainda acredito, a enfermagem vai ter uma amanhã melhor, mas hoje, nós não temos um líder dentro da enfermagem que possa estar tocando esse Conselho, sabe? Vislumbrando uma amanhã melhor, eu não vejo. Eu fui, assim, eu achava que o Conselho Federal era o supra sumo da natureza. O supra sumo onde você não tinha desvio de dinheiro, você não tinha. Porque, quer queira que não, está roubando pobre. Inclusive, no tempo em que eu estava trabalhando eu achava um grande absurdo: “Ah não, pega uma seringa pra você fazer uma injeção em casa e não sei o quê". Eu falava: "Mas gente, não vou levar. Se eu trabalho é pra mim ter". Ainda até umas pessoas que falavam: "Credo, que chatice". Eu falei assim: "Não, se é pra dar pra um doente fazer um curativo eu pego e dou, agora, se é pra mim pegar uma seringa, pra mim levar pra mim, pro meu uso, isso eu nunca levei”. Agora, eu nem mecho com mais nada na área hospitalar. A pessoa entrar num carro pra roubar é uma coisa assim que eu não me conformo. Eu não concordo e acho o cúmulo do absurdo. Eu sei que pode ser que eu esteja errada no meu ponto de vista, mas eu condeno e não aceito, acho assim, se é pra ficar preso ele tem que ficar preso não pra cumprir um sexto da pena, ele teria que estar cumprindo a pena integral. Ainda bem que tem outros processos pra serem avaliados e vai ser julgado. Porque na hora que esse homem sair de lá, ele vai vir como um trator pra cima de quem estiver no Conselho e eu espero em Deus não mais estar por lá, espero em Deus. Porque no ano passado eu fui várias vezes na penitenciária pra visitá-lo e sempre foi assim: "Eu vou sair amanhã e eu vou voltar pro Conselho porque lá não tem nada de errado, nada, nada, nada". Só que é assim, eram contratos bilionários sabe? De coisas assim, por exemplo, coisas mínimas, comprar lâmpada. Então eram assim, licitações de 80 mil reais de lâmpada, sabe? Coisas assim, mudar pra Brasília, que segundo a Lei do Exercício teria que ter uma sede em Brasília, isso, logicamente Brasília seria um 
lugar que ficaria mais difícil de ele ta pegando dinheiro. Então, ele sempre deixou isso de lado e sempre mostrou que isso daí não era uma coisa real e sendo que é uma coisa real e parece que, tudo indica que até o ano que vem a obra vai estar pronta, porque a gente já tem um terreno lá ganho, na época estava distribuindo os terrenos e coisas lá de Brasília, até isso o COFEN tem um terreno maravilhoso, no entanto, ele construiu uma casa pré moldada, pré-fabricada lá no meio pra dizer assim: "aqui é o escritório administrativo". Sendo que as coisas todas eram feitas no Rio, porque era mais fácil. Então, é um lado da enfermagem assim que dói muito, dói muito de você ver que estava dentro de um sistema. Eu realmente não sabia de nada, nada, nada, nada. Eu acreditava que aquilo tudo que ele estava fazendo, quando ele dizia que estava indo pra tal lugar, tal lugar, pra isso, pra aquilo e que tinha que comprar tal coisa, isso, aquilo, aquilo outro. Comprar mais um andar no prédio, lá no COFEN que seria a solução. Ah, minha filha. Acredito eu que ia uma parte, um percentual, pra ele e um percentual que nem um enfermeiro que é de nível sócio-econômico baixo consegue ter uma casa, praticamente uma mansão nesse país, nesse Brasil. Ele fala que não que não é rico. "A minha mãe me deu". Esses dias eu falei assim: "Nossa, mas você tem muitos recursos". "É, minha mãe era pobre, auxiliar de enfermagem, mas ela me deu condições, eu estudei fora e não sei o quê”.

Eu era a primeira secretária, daí eu assumi a presidência, fiquei até 2006 na presidência, aí saí. Nesse meio de tempo, teve outra eleição e pela própria contingência dele mesmo, do próprio ex-presidente que estava ainda preso, e que ainda está, ele mesmo fala que o pouco de conhecimento que eu tinha tido eu tinha que estar dando subsídios pra outra presidente que ia entrar e que era pra mim ficar. E eu relutando dizendo que não queria ficar, quer queira quer não minha licença no hospital ia terminar em julho de 2006 e que eu não ai ficar porque eu não ia, que a outra gestão ia até 2009, que é isso, aquilo e aquilo outro. Então, nos finalmente, eu acabei ficando. Eu fiquei no sentido de ajudar a outra presidente. No começo eu estava cega, eu não enxergava nada, depois eu comecei a ver que tinha alguma coisa ali de diferente e que alguém tinha que tomar uma providência e que alguém tinha que solucionar aquilo. Esse foi um dos motivos que eu aceitei a ficar. Agora, esse ano ta indo todos os processos e tudo pra serem respondidos. Ela tinha uma vontade política muito grande e ela tinha uma noção de administração pública boa, ela tinha assessores bons, enquanto que pra mim eles falaram que eu não tinha que ter 
assessores nenhum, que eu tinha que funcionar com o próprio corpo, como próprio conselho. Então, eu não posso ter assessores e não posso ter ninguém que conheça mais do que eu, então, eu tenho que ouvir aqueles que estão lá. Aí, no ano passado, em agosto saiu a minha aposentadoria, eu aposentei, fiquei lá no conselho só pra. Mas agora eu to de licença lá do conselho, porque realmente me fez ficar mal. Eu fui operada no final do ano de varizes, mas não tive um pós-operatório light nem nada, porque eu tinha excesso vascular crônica, então, daí eu tive mais repouso e tudo, então daí eu não cheguei a fazer tudo certo. Continuei tomando antiinflamatório, tudo com prescrição média, daí eu ganhei uma pequena pedra na vesícula, minha amiguinha, então daí essa minha amiguinha tava me deixando meio irritada, nervosa, porque há dias que você tem cólicas péssimas então eu falei assim: “Ah, eu vou sair pelo menos uns 3 meses, então, quem sabe, saindo do estresse e essas coisas, acalma um pouco e consegue evitar". Dá tempo de ir ao médico, se ele marcar pra fazer um bombardeamento, seja lá o que for, dá tempo de você ta indo no médico tudo direitinho, então, eu to de licença até junho, depois de junho. Mas ai, mesmo que eu volte, eu já não vou mais voltar pra ficar lá a semana toda, eu vou só assim tipo uns 2 dias na semana porque daí já dá pra presidente despacha as coisas se precisar fazer alguma portaria, se precisar fazer alguma coisa daí eu faço nesses 2 dias porque se não, porque se não desgasta muito a gente.

Exatamente [eram 3 reuniões por mês], agora passou a ficar a semana toda e eu vivo no hotel, eu não tenho casa lá no Rio. Porque naquele tempo, quando a minha avó morava lá, eu tinha casa, tudo. Depois manda minha avó pro asilo, manda a minha tia pro asilo e a casa ia ser invadida por tudo nessa Terra. Então a gente vendeu a casa lá e compramos o apartamento aqui em São Paulo, moramos aqui. Então aqui ficou a minha filha, ficou a minha mãe, eu não posso arrumar uma casa lá e ter uma casa lá e uma casa aqui. Então lá eu fico no hotel. Então o hotel mesmo, o melhor que seja, o melhor dos melhores, é muito caro e você não pode, eu não podia estar comendo nada que tivesse gordura dada disso e daquilo outro, eu não podia, então, de noite, eu não comia. Mas eu não podia ficar sem comer, então é meio complicado. Então daí eu falei assim: "É melhor eu dar uma pausa, estar melhorando e daí depois que eu tiver melhor". 
Olha, dentro do COREN eu também acho que praticamente eu não tive [situações de preconceito], pelo fato de que também, dentro da enfermagem tem muitos negros. Você tem a menina do departamento pessoal, só eu ela não é da área de enfermagem. Agora dentro da própria fiscalização, acho que só tem uma menina, uma negra. Agora, o atual chefe da fiscalização, a gente tem basicamente, nem todo mundo gosta do verde nem todo mundo gosta do amarelo, então ele tem logicamente algumas divergências, mas assim, não acredito que seja por causa do racismo, acredito ser mais assim por ciúme, vontade de estar ocupando aquele cargo o qual eu estava ocupando. Porque imagine eu, uma reles morta, negra, trabalho dentro de uma UTI, ocupando o cargo da presidência, de presidente do Conselho? Então, acho que isso incomodou muita gente, só que não chegavam a expressar, mas que isso era bem nítido.

$\mathrm{Eu}$ acho que talvez sim [tudo que aconteceu pode dar nova esperança a enfermagem], mas acho que vai ser um período. Porque vinha um período que era só ganhos, ganhos "que a enfermagem é assim, que a enfermagem é assado" e vinha mandato de segurança. Por exemplo, a 271 que era pra prescrição de medicamento, no entanto, quando saiu essa resolução, eu já sabia. O próprio G, eu falei assim: “G, nós não fazemos diagnóstico de doença, fazemos prescrição de enfermagem”. E ele disse: "Não se preocupe, deixe isso quieto, deixa isso pra lá! Quando começar a chover mandato de segurança, daí nós vamos ver”. Daí o que deu agora? Deu a liminar dizendo que tem que suspender. Deu aquilo que a gente tinha falado naquela época só que a gente não foi ouvida. Se você olhar, representa que a enfermagem tinha ganhos e que de repente agora, começou tudo a se perder, mas não que foram ganhos, foram máscaras que agora estão caindo. Por exemplo, todo auxiliar de enfermagem que entrou desde 2001 pela nova Lei de Diretrizes e Bases, ele não poderia mais ser auxiliar de enfermagem, pela resolução ele não poderia mais seu auxiliar de enfermagem, seria só um itinerante pra ele ser técnico. Só que nessa época eu também falei pra ele: "G, gente acontece que em muitos estados você não tem vagas no serviço público pra técnico de enfermagem, como por exemplo, o Estado de São Paulo", daí a presidente do Rio Grande do Sul disse: "Isso é uma bobagem. Até lá o governador já assinou vagas e coisa”. Assinou? Assinou coisa nenhuma. Então, antes que aconteça o que o ano que vem vai acontecer: uma chuva de mandatos de segurança que a gente vai ter que, desculpe a expressão, botar o 
rabinho no meio das pernas e registrar todos esses auxiliares de enfermagem. Então teve um simpósio agora e foi decidido que vai ser revogada a 276 e vai-se dar o registro de auxiliar de enfermagem pra aquele que ter na localidade, porque técnico de enfermagem aqui você não tem, na cidade de São Paulo, não tem. Teve as vagas que o Mário Covas ia assinar, morreu! Daí ninguém mais teve vontade política de botar isso na Câmara e tudo.

É o tipo da coisa que ta na Lei do Exercício, o pessoal fala "Ah, vai acabar o auxiliar?" Eu falo: "Gente, não vai acabar o auxiliar porque ta na lei. Se tivesse sancionado a lei e tivesse outra que tivesse dando, mas pra mudar uma lei, quantos mil anos vai?". Então todos que fizeram concurso público, a pessoa tem direito adquirido, porque se fez um concurso, apresentou na hora, no momento do concurso, apresentou inscrição provisória e valeu aquela inscrição provisória, então nós vamos ser obrigados a dar um registro definitivo, porque o concurso não tem validade de que hoje eu fiz o auxiliar de enfermagem, amanhã ele vai ser técnico de enfermagem. Pela escolaridade, amanhã ele seria um técnico de enfermagem, mas, pelo concurso prestado, ele prestou na função de auxiliar de enfermagem e ele vai morrer na função de auxiliar de enfermagem.

Pela própria lei, quem trabalha dentro de UTI, deveria ser somente técnico de enfermagem, então, o que essa resolução adiantou? Eu acho que essa resolução teve o seu grau de validade, porque daí você cobrou principalmente dos hospitais particulares a contratar o técnico de enfermagem pra trabalhar na UTI. Só que, infelizmente, eles sempre têm 2 serviços. Têm o serviço público e têm um serviço privado. Então, no privado, ele tem que ter um registro de técnico de enfermagem, agora no público, ele prestou concurso como auxiliar de enfermagem, além de tudo nós estamos onerando essa criatura em 2 mensalidades porque tem que pagar a do auxiliar e tem que pagar a técnico.

[Os auxiliares, hoje, estão fazendo faculdade direto] Não tenho nada contra a UniX, não tenho nada contra escola nenhuma, acho que a escola, você faz a escola, sabe? Se você quiser, você consegue desde que você tenha as condições mínimas dentro daquela escola. Então, o que acontece? Você tem muitos auxiliares de enfermagem fazendo cursos noturnos nas universidades. Então, daí o que você vai ter amanhã? Auxiliares melhorados é o que eu chamo. Eu não posso considerar esse 
menino, eles tiveram boa vontade, mas de boa vontade o inferno esta cheio. Porque você acha que aumentou tanto o número de processos éticos? Você tem que ver a quantidade de processo ético que tem, é uma coisa assim impressionante! É medicação que estava errada, é veia que estava errada, é diluição dada errada. Chegou lá no COFEN, até que eticamente a gente nem poderia estar dizendo, mas eu também não vou dizer o nome. Uma enfermeira, colega, ela diluiu a vacina que era da saúde de trabalhador. Que eles tinham que tomar? A vacina, eu sei que ela diluiu, ela tinha que diluir 5000 doses, aquela quantidade ela tinha que diluir 5000 doses, o que ela fez? Ela diluiu em $5 \mathrm{ml}$ e aplicou $1 \mathrm{ml}$ em cada criatura, advinha o que aconteceu? Deu hepatite em todo mundo, deu tudo quanto foi doença e uma das pessoas morreu só que, o que nessa época aconteceu lá no COFEN, eles falaram assim que foi um erro, imagina que ia estar crucificando a menina e tudo. Então, eu na aceito.

Uma coisa que eu acho que vai ser assim uma coisa muito boa pra enfermagem é o exame de proficiência. Isso nós estamos lutando e eu tenho muita fé, eu já to assim pro lado místico, mas eu tenho assim muita fé que vai realmente. Ta um grupo de trabalho já trabalhando no exame de proficiência e vai fazer cursos à distância para que as pessoas possam estar se atualizando e vai ser feito o exame de proficiência e quem não passar no exame de proficiência será cancelado e ele vai ter que estar voltando pra escola pra poder estar revendo conceitos, revendo as coisas. [Se essa prova for] De um nível muito baixo, você vai pegar a todos, vai fechar por baixo. Se for muito alto, ai [muita gente] não passa.

Não hoje [muita gente] não [passaria], infelizmente. Vai cria emprego. Aí que ta. É uma coisa que eu tenho muita esperança de que esse exame vai ser um norteador pra se definir inclusive não só carga horária, mas também o currículo. Porque você não vai poder pegar uma UniX e pegar uma USP, sabe? Não tem lógica, não tem nada, então, é o tipo da coisa que não dá. Agora, ao mesmo tempo, você tem um contingente de pessoal que, como diz o outro entre aspas "é um direito adquirido". Não sei até que ponto é um direito adquirido.

Eu acho que não, é um pouco da enfermagem [essa coisa de não discutir problemas], parece assim que é uma acomodação que as pessoas passam a ter, é uma coisa estranha. Eu falo assim: "eu não gosto desse crachá”. Eu tenho que ter um 
motivo pra dizer que eu não gosto desse crachá. Na enfermagem, eu não gosto desse padrão dessa seringa, por exemplo, você se aquiete, cale, porque isso aqui foi comprado não sei quantos mil e tem que ser usado esse tanto. É muito assim, parece aquele militarismo, aquela coisa assim. Talvez seja, apesar de que a Florence, coitada, todo mundo joga a culpa nela, mas ela em si, ela revolucionou, talvez seja um resquício dela, enfim, que ta alí, do horário e isso, aquilo ou aquilo outro, mas, ao mesmo tempo se dá honras e glórias pra Anna Nery. Agora, a Anna Nery, coitada, eu sinto a dor do parto, era uma mãe que queria ficar junto com os filhos soldados. Então, ela foi chamada de enfermeira e assim ficou como enfermeira, mas, de enfermeira ela não tinha nada.

Eu acho que você teria que estar lutando por uma enfermagem, sabe? Ensinar o enfermeiro a ficar ali dentro de uma UTI, onde ele lê o eletrocardiograma, ele vê a arritmia, porque uma arritmia mal vista, ela pode no final do plantão esse indivíduo pode estar indo a óbito. Se você olhou e você detectou aquilo no começo do plantão, se você ficou bobeando e, tomando café, de manhã você pode ter um óbito. Sendo que se você detectou aquilo, você foi lá e avisou e coisa. Por que eles gostavam de dar plantão comigo? Porque eu falava assim: "Eu sou chata, sou chata. Doutor, levante e venha ver porque aumentou o número de arritmia, está aqui registrado, levante e venha ver". Ai depois, às vezes vinha, às vezes não vinha, daí na hora que vinha, isso os que eram mais antigos e que me conheciam, falavam assim: “Ó, quando ela chamar, venha porque as coisas vão. Ela tem um sexto sentido". Eu falei: "Não é que eu tenho um sexto sentido, eu vejo, eu detecto". Não é porque eu to vendo aquele, que eu to dando banho, ou to ajudando a dar banho no outro lá ou to dando banho, to desembaraçando o cabelo do outro, to lavando outro e coisa, eu to de orelha em pé no alarme que pode ser uma coisa fatal, mas isso, hoje, não é passado. Na escola não se valoriza nada disso, então daí o que valoriza? Valoriza a prescrição de uma coisa que existe, por que existe médico? É pra ele prescrever.

Se o PSF tem uma demanda que você precisa ter um atendimento de 1 milhão de pessoas num espaço territorial "x", então, daí o que eu preciso pra isso? Preciso botar pessoal pra que cubra isso e não tapar o sol com a peneira. "Eu vou mandar o enfermeiro lá na casa", sendo que o enfermeiro seria muito útil no PSF de ter úlcera varicosa, ele tem que prescrever a evolução dessa úlcera, o curativo então eu vou ter 
que ir lá na casa dessa pessoa. $\mathrm{O}$ auxiliar de enfermagem vai segunda, quarta, na sexta-feira eu vou junto pra avaliar como foi a evolução da semana, pra mim poder tratar a evolução, o como vai ser a prescrição da semana seguinte. Agora, isso não é feito. Ela ta indo lá no PSF pra quê? Pra ver se os meninos estão vacinados? Ta, perfeito! Mas, ela teria que estar cobrando porque que não levou aquela criança pra vacina, estar programando que tal dia assim, assim vai-se um grupo aqui vai-se fazer a vacinas, sabe? Tinha que ser uma coisa dinâmica, não pra pegar o serviço do médico tinha que ser uma coisa com o objetivo do cuidado do paciente, sabe? Não que ela esteja errada e ela chega lá e ela vai fazer o peso da criança e a criança teve com peso menor. Pra que ela vai prescrever farelo de soja, vai prescrever não sei o quê. Não é função dela prescrever isso. Tem uma nutricionista que essa mãe tinha que ta lá, tinha que ta ensinando. Essa nutricionista teria que ta ensinando como é que faz o farelo de soja, como é que faz isso, como é que faz aquilo ou aquilo outro. Pode até na hora que a equipe multiprofissional chegar lá na casa dessa pessoa pra ver como é que está indo a evolução, porque dentro da parte da criança desnutrida também tem assistência de enfermagem pra se dar. Então, ela vai avaliar se a criança ganhou peso, não ganhou peso, é edema, aquilo não é edema, ver como é que está a evolução e não você ficar prescrevendo Capoten, prescrevendo isso, prescrevendo aquilo que isso não é função da enfermagem. Você vê no caso de pré-natal, que existe uma diferença muito grande no caso de pré-natal, com obstetras e o pré-natal com enfermeiras, mesmo que elas não sejam obstetrizes, só que agora, pelo pouco que eu entendi, essa enfermeira não pode sequer prescrever o ácido fólico.

Porque o próprio grupo médico ta se achando lesado porque esta se tirando o filão deles. Porque antes era a primeira consulta era do enfermeiro, ele prescrevia os exames, que eram aqueles exames básicos e a segunda consulta era com um médico. Se tivesse alguma coisa nesse intervalo, ela voltaria no pronto socorro e voltaria no grupo médico. Só que daí, o número de enfermeiros também é um número reduzido, daí o que ela faz? Ela delega pro auxiliar de enfermagem, esse é o grande " $x$ " da história. Ela delega pro auxiliar de enfermagem, ela delega pro técnico de enfermagem, o agente de saúde ta aí. É a hora em que tudo acaba virando nessa confusão. 
O agente comunitário não tem capacitação nenhuma, o atendente era até mais capacitado. Se torna até uma coisa mesquinha. Dentro de uma população carente, precisa de condições mínimas, mas o enfermeiro, no meu ponto de vista, teria muita condição de fazer a prescrição, a consulta de enfermagem, de fazer toda a anamnese sobre o ponto de vista da enfermagem e não sob o ponto de vista médico, deixa pro médico fazer.

Aqui [no COFEN], pelo menos antes de eu sair de licença estava fervilhando [a discussão se o enfermeiro pode ou não ser responsável pelo pré-natal de baixo risco], as próprias prefeituras, porque eles investiram em pessoal, em contratar enfermeiro pra eles estarem fazendo o pré-natal e tudo. Tem muitas localidades que eles já são, propondo casas de parto, então daí, precisa se dar uma boa, uma ótima estrutura para que essa casa de parto funcione sem dar problema pra mãe e pra criança. Então, ao invés de você constituir dentro das unidades condições de que essa mãe possa ser tratada no posto de saúde essa mãe seja evoluída e seja vista por todos os pontos de vista. Não. Joga-se tudo pra cima do enfermeiro como sendo o salvador da pátria e não é isso.

Então daí depois que você já ta um tanto enfartada de profissão, a parte ética, a parte, sabe? Você fala assim: "Meu Deus, a que nível estão essas escolas?!" E que montam uma realidade porque você está formando auxiliares melhorados. Você não ta formando enfermeiras, enfermeiros, sabe? Não que eu ache que a enfermeira tenha que ser aquela supra sumo, de coisinha, de toca, mas você tem que dar um apoio, você tem que dar um apoio a equipe, você tem que esta vendo certas particularidades no qual, que é um auxiliar melhorado não vê isso, muito pelo contrário, ele vê como sendo, por exemplo agora eu de enfermeira formada, eu vou pisar naquele auxiliar ou naquele técnico que esta trabalhando comigo. É essa a filosofia que você vê a vingança. Não vê o paciente direito, o importante é você e mais nada. Eu tenho muita preocupação com a enfermagem de amanhã. Você partia do princípio do qual você ia, você olhava o paciente, você fazia o exame físico, você olhava alí minúcias e tudo e, na hora que você se forma, o que você faz? Você tem 40 doente, no qual, mal e porcamente, dá pra você ver um dois. Daí você ta vendo aquele, daí o outro para lá no canto, você tem que largar tudo lá, daí na hora que você volta, vai fazer uma prescrição de enfermagem nas coxas. E a colega que te substitui diz: “Ah, não, não 
tenho tempo". Que é o grande "x", você não se beneficia da outra. Aqui na ortopedia teve um tempo que a prescrição médica tinha validade por 3 dias. Nesse tempo nem tinha prescrição de enfermagem, nem nada, ai se fazia a prescrição de enfermagem, mas assim, sinais vitais, isso, aquilo, aquilo outro, banho, isso, aquilo, então, sabe assim, umas coisas que não acrescentam nada, não orienta, não mostra, é uma coisa muito. Tem horas que eu falo assim, minha menina falou assim: "Mãe, uma coisa que eu tenho certeza que eu não vou fazer". Eu disse assim: "O quê?" "Enfermagem, a gente tem que ter somente um louco por família, o segundo louco, a gente tem que jogar no meio do mato, a gente tem que deixar preso numa árvore, então, eu vou fazer qualquer outra coisa".

Eu acho que foi mais uma questão social [minha filha não cursar USP], pelo seguinte, porque ela ficou em colégio particular desde o maternal, daí, na hora de prestar um vestibular, a turminha dela, todos ali, ninguém pensava em prestar uma USP. A turma dela e a turma do colégio em si, eles não incentivavam, tipo assim: "Olha, vamos estudar, vamos trabalhar pra poder a gente entrar numa USP para que os pais de você parassem de pagar". Mesmo que fosse assim, pelo fator econômico, que parem de pagar uma escola pra você. Não, o que se cultivava era assim que, o padrão ideal já que eles sempre estudaram em colégio particular, que eles mantivessem o nível de colégio particular e tivessem numa universidade particular. Na turma dela inclusive, eu fui a várias reuniões, como ela estava desde o maternal e foi até o colégio, eu sempre questionei muito isso com as irmãs. Elas falavam assim: "Não, não, não, nós estamos inclusive montando uma faculdade para poder os alunos continuar". Eu falei assim: "Mas, irmã, acho que não é bem por ai, a senhora ta criando os meninos dentro de uma redoma de vidro, na qual eles são impenetráveis, eles são daqui e eles vão continuar na turma em determinada universidade e esse tipo de coisa". "Ah, assim é muito melhor, pra eles não se misturarem". De estarem competindo se os pais tiveram condições de estar pagando até agora, então, deixa a USP pra quem nunca teve condições de estar pagando nada.

E ao mesmo tempo o que deu a entender: a criançada já vinha com aquele pensamento deste tipo, então, daí a hora que chegou a nível de colégio, a nível de se decidir o que vão fazer, você pode ver, na turma dela, ninguém prestou USP, ninguém prestou UNICAMP, não, pra não dizer, teve uma menina que prestou 
UNICAMP, mas também não passou. E vários deles entraram, começaram e desistiram no final do ano. Daquele curso, pegaram outro curso. É um padrão assim que, tem horas que eu paro e penso:, "Gente, será que vocês foram criados num mimo tal que vocês não conseguiram perceber o que é que vocês queriam fazer do amanhã de vocês?".

Mas você vê que esta sendo praticamente um empecilho você estudar pra prestar uma UNICAMP, pra você prestar uma USP ou pra você prestar uma UNIFESP [quando há uma dificuldade sócio-econômica]. Porque você tem nas federais e na USP, você tem o período integral, na hora que você tem um período integral, entre aspas, você impede que aquela pessoa vá trabalhar. Agora, na universidade particular, o que você tem? Por que você tem maior parte dos cursos noturnos superlotados? Porque eles trabalham e têm, entre aspas, um desconto astronômico e se você fizer o noturno é bem mais barato ainda. Então daí, o que a pessoa faz? "Se eu vou concorrer com 5 mil pessoas, ou eu vou concorrer com 500, mas eu vou pagar". Então assim, a filosofia do jovem de hoje, diz "eu pago, mas eu não vou concorrer com aquele outro". É grande [a concorrência], então quem vem de uma escola particular, não quer concorrer. Eles vão até pra uma medicina, eles concorrem pra uma medicina, porque é um status, mas ao mesmo tempo, você pode ver que tem muitos dos meninos que fazem medicina, que eles fazem Santa Casa, e sabe quanto ta uma Santa Casa hoje? Acho que ta 3.500. Ai que ta, nessas alturas é muito dinheiro, no entanto, papai paga. O meu, coitado ta já até morto que não tinha condições e tal, mas é muito difícil. Então o pessoal hoje procura de estar mantendo o status e indo para uma universidade particular, por quê? A concorrência é menor, papai e mamãe assumem o pagamento, então, já é uma comunidade muito maior e, quando encontra uma mãe como eu que fica enchendo o saco porque já tinha entrado em biomedicina, daí tava entre a FX e a UniX, eu falei assim: "Você fica na FX porque esse curso da UniX não presta". Só que é teimosa pior do que tudo. "Eu vou pra UniX". Eu falei assim: "Bom, na hora que você se formar você nunca que vai conseguir arrumar um emprego, escuta o que eu to falando". Isso eu fui lá e falei como o coordenador, eu falei: "Com essa carga horária, depois da reforma universitária, já esgotaram? Esses alunos vão ficar no limbo, eles não vão conseguir emprego em canto algum e nem se quer fazer um curso de pós-graduação, porque vocês não fizeram a base mínima". Nossa, o coordenador quis morrer comigo, quis 
morrer. Eu fali assim: "E de hoje em diante eu não pago mais a faculdade dela, pago uma multa porque eu to rescindindo o contrato e tudo". Paguei a rescisão do contrato e falei assim: "Você vai pra FX, vai pra onde você quiser, aqui na UniX você não vai fazer mais".

Ela foi, só que foi naquele período de 2005 que eu estava mais no Rio, quando eu cheguei aqui eu vi. Eu falei assim: "Não, não vou gastar meu dinheiro com esse curso, não! Ta fazendo FX”. A carga horária lá é bem melhor, o nível de aproveitamento é bem melhor. Eu tava certa. Mas, foi bem por esse lado. Tudo tranqüilo numa situação que papai paga, mamãe paga, então, pra que eu vou me desgastar? E o restante da turma, porque hoje eles acham assim, eles vão muito pelo que os pais da turma, então, a turma, o basal da turma é fazer tal coisa, então, vamos todos nós pra fazer a mesma coisa. Coisa que a minha geração era diferente, a sua foi deferente, já bem diferente da minha, e agora, eu vejo da minha menina ser bem diferente, bem diferente. É isso que eu falo, a gente tem que ver o que será dos nossos netos. Mas eu não consigo dizer o que será o amanhã dessa criançada, com a educação desse jeito. Essa irreverência total assim desse jeito. É complicado. Que presidente nós queremos ter? Quais são os líderes que nós vamos formar? Acho que isso é um dever de cada geração em estar formando um líder, pode ser até que seja um líder ruim demais. Porque o Lula seria da minha geração, é um líder que hoje a gente vê que não deu em nada, infelizmente. Foi-se dado um poder no qual ele não tinha condições pra tal e ta dando no quê ta dando, é governado pelos outros. Agora, da geração que estão aí, tem diferença muito bem porque hoje dentro do senado, dentro da coisa, não tem ninguém que assuma ou se volta ao sistema militar, veja bem, não tem. O socialismo hoje ta todo avacalhado. A gente tem que pensar que vai conseguir alguma coisa e que vai melhorar as condições.

Eu acho assim que é um trabalho muito bonito esse que vocês pretendem e vão conseguir estar fazendo. É bem provável que vocês vão conseguir um número muito mínimo de participantes. Acho que é assim, se vocês conseguirem uma por turma será que nem isso você não consegue? Eu vou ver se eu consigo entrar em contato com a $\mathrm{G}$, ou então você vê se consegue achar a AM e você vê com ela se ela tem o contato da D. Quem sabe, porque da nossa turma, eu acho que só tinha o que? $\mathrm{O}$ L era branco, aquele outro menino também era branco, o restante não tinha, só 
tinha eu e a D. Olha, isso é porque eu ainda vim de Ribeirão, porque se não ia ficar só a D e a DA também era aluna de escola pública.

$\mathrm{Na}$ escola em si você tinha muitos poucos negros, você tinha mais os funcionários. Entre os professores tinha a A e depois a D passou a ser professora. Dá uma perguntada pra menina ai na secretaria, talvez ela tenha até aposentado. É DS.

\section{Colaboradora 11}

Então, essa é uma pergunta interessante, etnia. Até, essa relação histórica também, até onde eu entendo esse conceito de etnia, eu não tenho uma etnia, mas eu pertenço a cor, a raça negra e me identifico como de cor preta. E etnia aqui no Brasil é uma coisa meio inexistente. Parece me que a gente não utiliza esse termo. Mesmo eu que, eu tenho uma aproximação com o movimento negro. Uma aproximação porque, num dado momento da minha vida eu estive dentro de um grupo que discutia a questão racial, aí eu me formei e fui trabalhar e logo no começo da minha vida profissional me vinculei ao movimento sindical e abandonei a militância do movimento social negro. Os meus amigos, que eu tenho de vida aí, as minhas, os meus momentos particulares, eles são militantes do movimento negro. Então até onde eu sei o movimento negro não usa essa terminologia etnia, quem utiliza são os indígenas. Os indígenas fazem questão, então ao IBGE ao fazer a suas pesquisas e solicitar a cor, raça dos cidadãos, eles colocam lá a raça, a cor, que são formas das pessoas se manifestarem quanto ao seu pressentimento identidade. Em vez que a etnia, até onde eu sei, nos movimentos sociais, é uma terminologia utilizada apenas pelo seguimento indígena e não pelos negros. Então eu desconheço, no Brasil, o uso da etnia negra, mas a raça negra, a cor preta, é assim que eu me identifico.

Essa discussão é polêmica dentro do movimento negro [a terminologia afrodescendente], isso divide o movimento, porque parte do movimento refere-se à comunidade negra e espera que assim sejamos denominados e outros reconhecem que, do ponto de vista histórico, nós fomos denominados negros pelo branco, enquanto estávamos, ou estivemos, os nossos antepassados na África, nós não éramos negros, nós fomos, a partir do momento, tirados da África e exportados para 
os outros continentes é que nos denominaram negros. E afrodescendentes então seria uma denominação na diáspora, para onde nós fomos levados, que nos remete então a nossa ancestralidade africana. Então, aqui nós seríamos afrodescendentes aí os americanos dizem os afrodescendentes, afro-americanos e aí vai. Então há uma divisão no movimento que é polêmica, que é isso: há um grupo que não aceita essa denominação de afrodescendentes e há outros que nos denominam negros, só que negros, então, é também uma denominação preconceituosa de um povo que foi identificado como tal porque era diferente dos brancos que os colonizaram, entre outros.

É, afrodescendente é meio complicado, eu mesma, eu confesso pra você que eu preciso de um pouco mais de embasamento teórico pra isso, pra eu me posicionar dentro do movimento negro a favor dos afrodescendentes ou dos negros, mas eu me sinto mais confortável de me autodenominar negra. Eu sou negra e assim, eu prefiro ser identificada como negra do que afrodescendente. Agora, eu aceito com mais facilidade alguém que ta numa condição de mestiço dizer que ele é afrodescendente, porque pra mim, eu interpreto como: "eu identifico nos meus ancestrais, alguém que pertenceu ao grupo afro", quer dizer, da África. Que tenha seus pais negros vindos da África, então eu sou afrodescendente. Agora, engraçado, eu me considero, por conta da minha cor ser identificada como preta, eu me considero como identidade negra e não como afrodescendente. É bem maluco isso. São coisas do Brasil. Porque nos classificam assim. São coisas do Brasil. Então você perguntou qual seria mais correto, então é uma discussão política aí, colocar afrodescendentes ou negros, eu, particularmente, eu me identifico como negra. Eu considero a mais correta.

Faz muito tempo [que eu me formei]. Nós concluímos o nosso curso em julho de 1979. Eu sou da turma que fez greve e que perdeu aí um semestre do curso que acabaria. Nós estávamos falando isso, eu estava com a $\mathrm{C}$ de manhã e nós estávamos falando isso. Então, tanto a turma dela, que é a minha veterana, como a minha turma fizemos greve um mês e com isso a gente perdeu o curso de habilitação, naquela época, ou de especialização, quer dizer, a habilitação depois na reforma lá do currículo foi definido como especialização. Naquele tempo, o curso era de cinco anos, mas a gente fazia, adiantava essa especialização, essa habilitação no verão. Então a gente tinha férias em dezembro e em janeiro a gente já voltava pras aulas. 
Então nos quatro anos tendo aula janeiro e fevereiro, nós ganhávamos um ano. Então fazíamos o quarto, tínhamos o quinto ano incluído e saímos do curso com essa habilitação já. Quatro anos mais essa habilitação e saímos com dois diplomas. Como nós fizemos greve, nós fomos punidos e saímos. Então a minha turma saiu no meio do ano de 1979. Entrei em 1976 e saí em 1979.

Eu passei no vestibular, depois o primeiro ano da FUVEST. Eu fiz vestibular em 1975 pelo CECEM, ainda era o CECEM, pra você ver como é velho isso, que dividia as áreas em biológicas, exatas e humanas. Isso era o CECEM. Em $1975 \mathrm{eu}$ coloquei as opções odontologia e enfermagem. Aí no ano seguinte, que era a FUVEST, que unificou a prova, essas três áreas em uma única prova, eu inverti a opção, eu coloquei enfermagem e depois odonto e foi isso. Aí eu entrei. Ele era universal, não se tinha cotas. Nossa, nem se discutia isso. Nossa, anos setenta, nem se discutia isso. Era um único vestibular para todos que queriam ingressar na universidade em qualquer área, fosse humanas, fosse exatas, fosse a nossa que é biológicas.

$\mathrm{Eu}$ to fazendo toda a minha carreira pós. Eu fiz especialização, duas. Eu fiz uma que foi denominada especialização em Saúde Pública, eu fiz junto a Santa Casa, e depois eu fiz especialização em enfermagem em Saúde Pública pela Faculdade de Saúde Pública, essa foi a segunda. Aí depois eu fiz mestrado em Saúde Pública pela Faculdade de Saúde Pública e agora eu estou fazendo doutorado aqui na Escola de Enfermagem.

Então, hoje foi o dia de olhar para o passado. Eu tava lá com os seus colegas de curso da disciplina lá na Unidade VD, e a $C$ fez uma brincadeira e perguntou: "quando você vai fazer trancinhas no seu cabelo" e eu respondi pra ela: "Então esse final de semana eu vou porque é o meu aniversário". E ela me perguntou "quando é seu aniversário?”. E, assim, vou fazer cinqüenta e um anos domingo. É só fazer as contas, se eu saí em 1979, faz 23 anos. E eu to me sentindo velha para pós. Porque hoje as meninas fazem mestrado com 23 e fazem doutorado com menos de 40 . E eu to fazendo doutorado ás duras penas, ralando lá aos 50 anos, quando muitos já param a vida acadêmica. Então, nesse contexto que você ta vivendo, que nós estamos vivendo, eu to velha pra um doutorado. Mas é isso. Eu to no doutorado agora, quase trinta anos de formada, me formei em 79 e nós estamos em 2007, quer dizer, daqui 
dois anos eu vou fazer trinta anos de formada e agora que eu to fazendo doutorado. As minhas colegas de turma, lá da faculdade, todas elas (lista as colegas) são livre docentes. Não sei se alguma delas já é titular. Então, elas são todas da minha turma, então eu to atrasadinha em relação a elas. Mas existe vida após os cinqüenta, viu? E eu não escondo, porque você começa a dizer que viveu em 78, fazendo o que, porque aí as pessoas começam a fazer conta. Eu sou solteira, não tenho filhos, mas eu tenho amigos que dizem: “Aí meu filho fez 23”, bom, se seu filho tem 23, então você foi mãe e você tem 43, aí começa. Então, não adianta esconder, as pessoas começam a fazer conta.

Apoiar sim, sempre me apoiaram [minha família], porque eu fui, até bem pouco tempo atrás, a única pessoa da família que chegou ao nível universitário. Então eu sou filha de um pai, falecido, que fez o ginásio. Que há cinqüenta anos atrás, quando eu nasci, ter um ginásio era ter uma alta escolaridade, e ele tinha o ginásio. A minha mãe, formalmente, ela foi pra escola por seis meses, o que a gente identifica como analfabeta funcional. Ela consegue assinar o nome, ela faz todo tipo de conta e nunca erra, mas ela tem dificuldade de ler um texto e interpretar. E eu sou caçula de uma prole de seis. Minha mãe criou quatro. Até eu ir pra universidade eu fui a primeira, então sendo caçula meus irmãos mais velhos não alcançaram a universidade eles ficaram no nível do colegial, agora denominado ensino médio. $\mathrm{O}$ mais velho fez curso técnico, isso, técnico em contabilidade, depois de casado, depois que eu terminei a graduação ele já era casado, já era pai de família quando ele voltou e foi pra universidade fazer contábeis. O outro não acessou a universidade, o outro também não acessou a universidade e eu fui a única a acessar a universidade. Então a minha família, meus pais, sempre apoiaram, porque era muito bonito, era muito orgulhoso ser mulher, ser caçula e acessar a universidade. Isso era muito importante, pra família assim, mais próxima, eu fui por muito tempo a primeira que acessou a universidade, a única, a única que tinha acessado um curso universitário. Então foi muito importante, de certa forma todo mundo apoiou. Ninguém falou: "Não, não vai fazer", ninguém nunca fez isso.

Então, eu digo que foi difícil [escolher a enfermagem] porque eu venho dessa origem humilde, mesmo tendo percorrido toda a trajetória de escolarização na escola pública, eu fiz somente um ano numa escola privada, justamente por isso, porque eu 
era a única menina e o sonho da minha mãe era que eu estudasse num externato. Então ela colocou, meu primeiro ano de escola foi numa escola privada que era uma escola religiosa. Aí não se conseguiu pagar a escola e eu fui pra um grupo escolar que era a escola pública. Então eu fiz o ginásio naquela época na escola pública, o colegial na pública, consegui entrar numa universidade pública e continuo na pósgraduação no ensino público, então eu nunca paguei os cursos, a não ser inglês, línguas e tal, foram as únicas coisas que eu paguei na minha vida, mas a formação escolar eu fiz na escola pública. Então a dificuldade que eu tive naquele momento era que eu tava mantendo um curso que era período integral, então quando alguém me comparava com alguém da família, "Ah, fulano faz letras, fulanos faz contábeis", podia fazer no horário noturno, trabalhava durante o dia e fazia o curso a noite. Eu não tive essa oportunidade porque estudava o dia inteiro. Quando as coisas apertaram, no segundo ano da faculdade, depois da primeira disciplina específica, naquele tempo eles empregavam os estudantes na função de auxiliar de enfermagem, então muitos de nós, naquela época, trabalhávamos a noite, na função de auxiliar, porque já tínhamos percorrido aquelas disciplinas básicas no primeiro ano. E as duas disciplinas básicas da enfermagem, que era fundamentos e, ou enfermagem médica, ou enfermagem cirúrgica, e aí o serviço privado nos empregava a noite. E eu fiz isso durante sete meses. Eu sempre brinco que foi uma gestação prematura. Foi o tempo que eu consegui agüentar fisicamente, porque estudava o dia inteiro na universidade, dava um plantão de doze horas e ia pra universidade estudar mais um dia inteiro. Aí dormia essa noite e no outro dia começava tudo de novo, mais um dia inteiro na faculdade, a noite inteira de plantão mais um dia inteiro na faculdade e aí que ia pra casa dormir. Eu consegui agüentar sete meses, porque tinha dia que eu não conseguia parar acordada depois que ia pra faculdade do plantão. Durante a manhã que era estágio, aquela coisa agitada, eu me mantinha acordada, agora, depois, de um dia inteiro de faculdade, um plantão e uma manhã de estágio e o almoço, impossível ficar com o olho aberto. Então eu não conseguia estudar, meus cadernos viviam riscados, que eu tentava escrever e riscava, caía, dormia literalmente em cima do caderno. Aí, conversamos em casa e a única possibilidade que existia era a minha mãe associar o trabalho doméstico com o trabalho fora de casa, então ela passou a trabalhar fora de casa, para poder me manter na faculdade. E foi isso que aconteceu. Então a grande dificuldade que eu tive foi a dificuldade de me manter na 
universidade, apesar de pública, eu precisava ter uma condição mínima pra arcar com todas as despesas de um estudante. Quem me manteve na faculdade foi minha mãe trabalhando como doméstica.

Não tinha bolsa, a faculdade pública naquela época não tinha bolsa. veja, quem era do interior e não tinha como se manter aqui tinha o COSEAS, mas eu não era do interior, eu tinha família aqui, tinha residência, morava com a família. Meus pais eram vivos estavam empregados, então eu de fato não procurei bolsa. Não me lembro se tinha bolsa nessa era, mas eu fiquei na dependência da família e, no caso, quem me assumiu, quem me bancou financeiramente foi a minha mãe, nessa condição, ela saiu pra trabalhar. Mas eu não fui buscar isso no curso não [uma bolsa], talvez tenha sido uma falta de esclarecimento meu. Ou então os bolsistas eram esses, de fora, que não moravam com a família.

Eu comecei a trabalhar com dezesseis anos. Eu morava aqui nessa região oeste, do lado de uma indústria. Tive uma adolescência muito difícil. Você não tem idéia do que era. Meu pai era funcionário público, nessa condição numa hierarquia de qualificação inespecífica, era porteiro, nessa condição tinha um salário diferenciado porque era zelador de um prédio da Secretaria da Fazendo, um depósito. E ele era zelador e nós morávamos lá. Mas era um salário pequeno para nossas despesas. Eu era menina, precisava me vestir e tinha toda aquela coisa da adolescência. E eu tinha muita dificuldade, tinha uma roupa pra sair, um sapato, enfim, a gente tinha muita dificuldade. Então assim que eu me percebi adolescente e em condições de concorrer a algum cargo eu fui buscar uma ocupação, e o meu primeiro trabalho foi numa fábrica do lado de casa. E acabou não dando certo, eu tinha uma escolaridade maior do que aquelas trabalhadoras dali e acabei sendo estimulada a ir buscar uma coisa maior do que trabalhar na indústria numa jornada de oito horas na linha de produção. Aí ta, aí eu fui ser recepcionista de um escritório. Aquela coisa de atender telefone, de arrumar arquivo, de levar uma correspondência no correio. Aí também eu fui estimulada a fazer uma coisa melhor, porque eu estava fazendo colegial na época. Como eu era menor, eu prestei uma prova pra ser mensageira do Hospital do SPE. Mensageira era um nível menor, utilizada como um office-boy interno. Nós levávamos papéis, pedidos de exames e tal. Tudo que era papel era conosco e o material biológico era com o atendente naquela época. E eu fui trabalhar como 
mensageira no Hospital do SPE onde eu via a enfermeira atuando. Era o máximo. Eu achava maravilhoso ser enfermeira. Um must. Aí eu quis ser enfermeira. Hoje eu não acho que é the must, mas é uma bela profissão. E você tem que gostar do que faz, na verdade é isso mesmo, é você gostar antes de ser. Muitas pessoas escolhem a profissão e aprendem a gostar. Não. O que me levou foi aquele sonho de ver aquela pessoa atuando, naquele lugar, daquela forma, então o ideário me levava a escolher a enfermagem. Foi isso que me levou a escolher.

Não, não. Eu não tenho essa percepção não [de ter sofrido preconceito por ter escolhido a enfermagem]. Quando eu escolhi não. Na graduação também não. Eu não me percebi discriminada lá. A minha percepção era da nossa dificuldade social. Eram duas negras na sala de aula, a outra da minha turma, que você deve ter manipulado lá as fichas era a $\mathbf{M}$, éramos as únicas duas, então nós nos percebíamos pouco, era muito pouco. E a minha aproximação com o movimento negro fazia perceber isso. Nós éramos pouco observadas, particularmente na universidade, mas eu não me senti vista de outra forma, mas, eu não vi, eu não percebi que as pessoas me olhavam diferente, mas nós tínhamos a velha cobrança que é implícita, que é assim, nós somos negros, então nós não poderemos ser menor do que os outros. Então isso sempre veio junto comigo, "Não seja pior que os outros, não seja pior que o branco. Você não é pior que o branco, você é igual". Mas pra eu ser, pra eu ficar igual, eu tinha que me esforçar muito, porque eu era de uma família pobre que não tinha o hábito de leitura, que não viajava nas férias. Eu me lembro que, um dos sonhos da minha adolescência difícil era fazer inglês, porque as pessoas que faziam a UC, ou a CI, que era o must naquela época, ganhavam como prêmio ir para Disney World, lembra? Você não lembra, não era da sua época.

É, eu estudei o ginásio e o colégio eu sempre fiz em Pinheiros. Pinheiros sempre foi reduto da classe média, então os colégios que eu estudei o ginásio e o colegial era reduto da classe média. Classe média, burguesia daquela época mandava seus filhos pra escola pública, e eu estudei em bons colégios, estudei no FD, que era o melhor colégio dessa região, e aqueles adolescentes, meus colegas de turma, tinham atividades extras a escola que eram inglês, a natação e eu me via sempre num ambiente freqüentado por essa classe média, mas eu não tinha as mesmas condições. Então pra eu ser boa aluna eu tive que estudar muito e sozinha, porque não tinha pai 
professor, mãe professora, pai médico, ou pai advogado. Meu pai era um simples porteiro e minha mãe dona de casa que mal sabia assinar seu nome. Então essa era a dificuldade que tínhamos, e nos cobravam o tempo todo, para podermos nos igualar em termos de resultados. Eu só fui perceber claramente a discriminação quando eu fui pro ambiente de trabalho. Aí sim.

Então, eu fui, nessa época a gente saia da faculdade e tinham cinco empregos pra escolher. O mais comum era BP, então eu fui pra lá. Eu me formei em julho e em outubro eu tava empregada. Bom, aí tinha o padrão, que era o padrão do serviço privado. A cor do uniforme, a cor da meia. A cor da meia era cor de mel e eu sou bem pretinha, então, por aquela meia cor de mel na perna era muito estranho, era motivo de gozação minha das minhas amigas, das minhas primas, porque é uma cor de nada, é uma cor muito estranha. Porque era assim que a indústria nos tratava, Nós não existíamos para a indústria de cosméticos, enfim, pra qualquer coisa aí. Então era muito estranho, se vestir de determinada maneira, usar acessório que eram do padrão da moça branca. O cabelo, eu sou dos anos 60, da geração black power, jamais que poderia usar o cabelo assim, mesmo porque eu seria chamada a atenção. Então tinha que ser o cabelo preso ou alisado. Eu me lembro que eu usava trancinha. Então a supervisora chegou perto de mim e "Como você faz isso no seu cabelo? Como que é isso?". Ela não pode me proibir de usar a trancinha porque era muito bonita e chamava a atenção, porque era bonita. Mas era uma coisa que era diferente do padrão daquele local, assim como a cor da meia. Eu comecei a falar da meia, eu respondi uma outra pesquisa e usei o mesmo exemplo. Como eu não gostava da cor da meia eu tingi a meia, e a supervisora viu, e ela me xingou, ela me chamou e perguntou: “que cor é essa de meia que você usa?" e eu "eu tinjo a minha meia", aí ela "procure usar a meia comum". Porque eu tingia a meia de marrom, porque era o que nós negras habitualmente fazíamos, porque o mercado não oferecia outra cor de meia e nós usávamos uma tintura e colocávamos a meia de nylon, no meu caso era meia kendal, que eu também tingia para ficar mais escura e fui chamada a atenção diversas vezes. Então tinha essas coisas ne, a aparência era essa, de boa aparência era dentro desses padrões de mulher branca, então era isso. Então eu passei a ver a discriminação a partir daí, do local de trabalho. E outra coisa era, quando se dirigiam a enfermeira, que era eu, e eu ia eles olhavam: "Você é a enfermeira?", as pessoas tinham que confirmar, "Você é a enfermeira chefe?", então eu "sim, enfermeira 
chefe". Eu tava sempre de crachá, o uniforme era padrão, usava uma cor e o uniforme, a atendente usava uma cor e o uniforme, mas as pessoas precisavam confirmar que aquela pessoa naquele uniforme era a enfermeira chefe.

Não [mudou a “confusão" entre quem é a enfermeira], porque recentemente eu assumi a gerencia de um hospital aqui do município de São Paulo, então as pessoas se dirigiam á sala de gerencia de enfermagem, que tinha uma secretária, e a secretária anunciava a pessoa. Quando a pessoa entrava na sala da gerente ela só tinha uma alternativa, encontrar a gerente de enfermagem, então a maioria das pessoas perguntavam: “A senhora é a chefe de enfermagem?”. Então isso denota a surpresa que a pessoa tem em lidar com uma pessoa naquela função sendo negra. Isso agora, em 2002, tem cinco anos. Isso é muito comum, das pessoas. Infelizmente nós negros também nos deparamos com isso em alguns momentos, porque ás vezes você vai em algum lugar, por exemplo, é difícil você ir num médico negro, então, se por acaso você for passar em algum lugar e tiver lá uma criatura negra sentada de branco naquele lugar você pergunta: "você é o que você diz?", porque eu também não estou acostumada a nos ver naquela posição. Isso é comum que as pessoas façam, inclusive nós, porque a gente se vê pouco nesses lugares.

E eu tenho colegas, outros enfermeiros que eu encontrei por aí que estão em escolas privadas. Enfermeiras negras, bom, têm algumas porque, como eu te falei, eu andei pelo movimento sindical, então, na época em que a ABEN teve uma chapa de oposição, um grande momento na enfermagem brasileira, que foi quando a presidente da chapa era a MJ, uma enfermeira negra, minha "ídala", porque eu tenho uma admiração enorme por aquela mulher. Ela era comunista, mulher, negra, assume a ABEN nacional e teve uma participação muito importante naquele momento, de dar as voltas na enfermagem brasileira, de por uma postura política, que até então a gente não tinha. Na verdade tinha uma postura política que era contra hegemônica, até então a ABEN e suas direções eram conservadoras, elas estavam sempre fugindo de questões hegemônicas. Aquela chapa de gestão contra hegemônica veio para romper com a condição de organização da nossa categoria. Então são poucos os exemplos, a gente tem alguns nomes, mas na Universidade de São Paulo eu não tenho, bom, você tem a F, ela é negra, a M, que era diretora da escola, ela é parda, não sei se ela se assumia como negra ou não, mas era parda. Era naquele tempo, não 
sei se ela ainda vive ou não. Eu não sei. Eu já lecionei várias vezes e tive a oportunidade de ser convidada a acessar a universidade privada porque era um propósito que permitia conciliar o meu cargo no serviço público que eu tenho a mais de anos, eu estou na PX desde 1981, então vai fazer agora mês que vêm 26 anos, é, então quando eu me vinculei, no segundo vínculo, era na condição de descer desse cargo e começar uma outra carreira. Então eu sempre raciocinei assim: "Ah é 40 horas e eu vou ter que sair de PX? Ah, então não quero. Não é 20 horas? Então dá pra conciliar". Então foi sempre assim que eu raciocinei. Recentemente teve um concurso lá na saúde coletiva, que onde eu gostaria de trabalhar, eu gostaria de trabalhar na Universidade de São Paulo, no departamento de Saúde Coletiva, era uma carga parcial, mas a prioridade era o outro vínculo, era conciliar com doze horas de jornada na universidade. Aí eu pensei: "ah, não quero", porque agora, mais de vinte e cinco anos, eu não vou deixar a PX para me vincular a universidade pública. Mesmo agora, concluindo o doutorado eu também não quero ser docente agora de 40 horas, percebe? Então, mas eu me candidataria, nesse momento, a uma prova para a universidade pública, pra encerrar minha vida na num serviço público, porque é uma questão ideológica, prestar serviço do público e não do privado. Porque, inclusive, o privado, nessa visão de mundo que eu tenho está ali para defender o lucro, onde o empregado é sempre empregado. Então essa primeira experiência que eu tive no privado, onde ali a gente era tratado dessa forma, de estamos ali para cumprir. Isso há trinta anos atrás, mas era assim, era extremamente autoritário, pouco exigiam da gente pra pensar, porque as coisas já vinham decididas e tal. E eu vejo o serviço privado muito dessa maneira, você está lá pra cumprir interesses de uma direção que não está a serviço do público, ela está a serviço do privado. Daí eu não ter afinidade com o serviço privado. Daí eu não ter vontade de estar no serviço privado, muito pelo contrário, eu quero estar no serviço público, e também porque agora eu acho que já mudou. Você já vê muito mais enfermeiras negras no serviço privado, mas quando eu me formei não tinha. Vá buscar identificar enfermeiros negros, de pele mais escura, no HX pra ver quantos você vai encontrar. Vai identificar enfermeiros negros, de pele mais escura, no XX, onde existe uma prova de seleção pra ver quantos você vai encontrar. Enfim, vai nesses que são top de linha pra ver se você vai encontrar. $\mathrm{O}$ fato e não encontrar me representa uma seleção, uma preferência por 
um outro modelo que não o negro, porque você tem muitas enfermeiras negras, mas porque elas não estão lá?

Mudou um pouco. Há trinta anos atrás, quando eu me formei você não encontrava uma enfermeira negra por lá, agora você encontre uma ou duas. Não dá pra essas instituições, hoje, deixar de empregar. Mas elas empregam o mínimo, o mínimo possível. Por isso eu digo que mudou, mudou um pouco, porque hoje tem uma pressão social que aponta isso. Nós do movimento negro apontamos isso. Não tem negro na mídia, não tem repórteres negros, não tem apresentadores negros. Os atores negros vivem fazendo determinados papéis, não é? Nós, eu digo a nível de público, quantos de nós negros já assumimos cargos de direção? Então, nós temos um número significativo na rede pública, mas a ascensão nessa carreira é muito difícil, é estrangulada. Ela não é facilitada pra nós. Muito pelo contrário, ela é dificultada. Tanto é que você não vê nós, enfermeiras negras, chefiando hospitais de São Paulo, públicos ou privados. Nós estamos neles. No público então, muitos. Quantos negros não têm em hospitais públicos do estado? Mas não na direção. Então isso configura ainda uma situação de preconceito, de racismo. Mudou? Um pouco, em relação há trinta anos atrás. Trinta anos atrás não tinha agora você encontra um ou outro, ou manifestação expressa das pessoas individualmente, ou do movimento organizado dizendo: "Olha, não tem".

Eu sou coordenadora de uma equipe. Eu trabalho, mas não tenho o ônus da função de chefia. Eu poderia ter, hoje, pela minha trajetória outro cargo de coordenação lá, ou se eu tivesse na assistência ser a chefe de uma unidade de saúde, ou ser coordenadora de uma área temática. Poderia ser, mas não sou, assim como a maioria dos negros não são coordenadores, chefes, secretários. Não são. Teve um período, essa foi outra brincadeira da minha vida. Um período que foi de nove meses, em que eu fiquei na gerência de um serviço de hospital de médio porte da rede municipal. Foi a convite de um diretor com quem eu trabalhei inicialmente nesse hospital que não tinha sido inaugurado ainda, então ali todos, enfermeiros, médicos, fisioterapeutas, nos fizemos profissionalmente, porque éramos todos ali muito jovens, praticamente o segundo emprego de todo mundo. E o hospital começou com a gente lá dentro. Nós fizemos uma prova pública e começamos a ser capacitados dentro do hospital que ainda não tinha sido inaugurado. Então quando inaugurou, 
todo mundo tava muito jovem, com muita garra pra trabalhar, pra criar. Então o que eu aprendi, a ser enfermeira, foi lá naquele hospital e como trabalhávamos juntos a mais de dez anos o médico me fez o convite para chefiar um outro hospital da rede, que era um hospital da zona sul, enfim. Aí eu fiquei nessa função, mas também foi interessante porque eu fui a primeira enfermeira negra daquele local e tinha outras tantas enfermeiras negras, que também, até aquele momento não tinham sido convidadas para fazer chefia de nada. Então naquele momento eu fui conhecendo as equipes e designei uma, que era negra, pra ser chefe da equipe, não porque ela era negra, mas porque ela tinha o perfil pra assumir e porque já estava ali há muito tempo. A outra era do pronto socorro, então ela foi ser chefe do pronto socorro e assim foi. Mas até então nenhuma delas tinha sido convidada a assumir a coordenação, a gerência de nenhum serviço daquele serviço de equipamento público. É natural que as pessoas não nos vejam nesses lugares. É uma coisa que a gente faz, na nossa condição de negra, a nossa invisibilidade, e é um aspecto que eu to, não sei se eu comentei com você que eu vou fazer uma palestra, e eu to me subsidiando para fazer essa discussão, da invisibilidade do negro. Então nós estamos, nós somos $47 \%$ da população brasileira e ainda temos que confirmar "você é médico? Você é juiz?". Bem recentemente foi designado o primeiro ministro do supremo negro. Recentemente nós temos uma ministra, uma mulher negra. Senador nós só temos um, não tem outro, Governador, nós temos um. Prefeito nós tivemos um e é isso. Nós não somos visíveis em alguns lugares da sociedade brasileira, então há de se questionar por quê.

Sim, a resposta é sim [passei por momentos em que houve preconceito racial]. Porque nos é definido um determinado lugar na sociedade, que não é lugar de visibilidade, que não é lugar de comando, que não é lugar de ponta de poder. Nós sempre estamos embaixo dessa pirâmide social, dessa hierarquia social, ou somos intermediários, então eventualmente nesse lugar de intermediários, alguém sobe, mas logo depois desaparece. Mas não é um lugar de constância, um lugar natural. É sempre motivo de notícia, de torcida, de comemoração. Se a gente consegue colocar, por exemplo, MR, foi o movimento negro que colocou. Num governo democrático, que se diz de direito para todos, ele não podia deixar de discutir, de enfrentar a questão racial no país. Como ele vinha de movimento, ele tinha que recolher que essa questão é uma questão que vem sendo discutida e cobrar da sociedade brasileira, 
porque se ela ta lá é porque tem um movimento que colocou ela lá. Assim ficou, ou você se destaca pessoalmente, ou se negocia, se tem alguém que permite que você ascenda para aquele lugar, porque normalmente nós não estamos no comando.

O que melhorou muito [em relação ao preconceito racial] foi o governo da L. Ele foi um marco porque escancarou as diferenças. Ela fez um governo para os oprimidos, não foi? Então fez um governo pra mulher, fez um governo para o pobre e fez um governo para o negro também. Então na saúde, lá foi o primeiro momento que começou a se discutir a saúde da população negra, a inclusão do quesito cor nos formulários dos serviços de saúde. Foi o primeiro momento que veio discutir a questão racial mesmo. No governo como um todo, não só na saúde, mas na educação, na segurança. Então, nós estávamos falando de gestão, essa foi um grande marco para nós. Desde então a gente tem tentado avançar e não recuar naquilo que conseguimos. Então tem vezes que a gente faz muito esforço para avançar.

Eu acho que eu falei bastante. Eu acho que o que a gente espera, agora falando das minhas expectativas, é que a gente consiga trazer o jovem negro pra dentro da universidade pública. Porque hoje, e agora eu vou falar da família, dos amigos, os nossos jovens, das nossas famílias, eles estão acessando a universidade, só que a privada. Eles acham que concorrer na USP é difícil, então buscam outro caminho. Muitas vezes, por conta da razão da família, a família banca ele na universidade privada, ou ele tem bolsa. Mas ainda na universidade pública os negros representam uma parcela infinitamente pequena quando comparada ao universo de estudantes que nós temos no ensino médio. Então hoje, na sua turma, quantos negros tem? Então, olha pra sua trajetória de quatro anos e veja quantos negros estão dentro da Escola de Enfermagem da USP na sua trajetória de 4 anos. Veja quantas enfermeiras negras estão na pós-graduação da USP na sua trajetória acadêmica. Quantos docentes negros têm dentro da universidade. Da Escola de Enfermagem da USP. Então a nossa expectativa é de que nós possamos ocupar esse espaço á exemplo de qualquer outra raça, porque nós não somos minoria na composição da população brasileira. Então nós deveríamos estar ocupando esses espaços. Dentro da universidade pública, seja no banco como alunos, seja na sala como docente. Seja como diretor, como direção. A USP está agora na gestão da primeira mulher na reitoria. Têm quantos anos? 75? Então, agora a primeira mulher na reitoria e eu 
espero ver o primeiro negro na reitoria da USP. Na direção da Poli, da FEA, da Escola de Enfermagem.

Acesso a universidade, eu diria a você que é um problema sócio-econômico e uma condição desfavorável, principalmente quando comparado a população branca. Além disso, nós também discutimos que quando você tem dois candidatos para uma mesma função, o preterido é sempre o negro. Então se eu me candidatar a uma vaga como enfermeira no hospital X, eu tenho que ficar atenta para ver quem é que está concorrendo comigo. Muito possivelmente, dependendo do local, eu serei preterida por ser negra. É assim que a gente explica porque não tem negros na direção da escola, do banco, da empresa, porque nós somos preteridos se comparados a outras raças. E o estudante aqui na universidade tem uma condição social desfavorável e, além disso, a inserção de seus pais também, historicamente, é desfavorável.

\section{Colaboradora 12}

Sou afrodescendente. Me formei faz tempo, em 1988, o curso. A graduação em doze de janeiro de 1989. [Fiz] Licenciatura na Faculdade de Educação e, no mesmo período, habilitações em Saúde Pública. E depois fiz especialização em Saúde Pública na Faculdade de Saúde Pública mesmo e depois eu fiz o de Epidemiologia Hospitalar na Unifesp e, atualmente, vou iniciar outro curso.

[Minha família] Apoiou minha decisão. [Entrei na EEUSP] Através de vestibular universal. Na minha época, isso o que, em 84, isso foi quando prestei vestibular, não existia nenhuma separação, era vestibular mesmo, para todos, hoje tem parcelas para afrodescendentes, existe para negros, existe com uma série de outras vantagens na minha época não tinha nada disso.

[Fiz enfermagem] Porque ela é a melhor, porque eu queria ser enfermeira, eu sempre quis ser enfermeira. Por que a enfermagem vê o ser humano como um todo, ela está mais próxima do ser humano, aos meus olhos, ser enfermeira. Parece até uma frase pronta, mas é o que realmente eu penso, não era difícil sentir isso, é está mais próximo das pessoas, existe uma quebra de barreiras, e aí eu posso prepor a existência, por parte de algum usuário, por que não é muito fácil entender o dia-a-dia. 
E eu como enfermeira, pelo contrário, eu sinto que o usuário se sente mais à vontade em está expondo um mundo de coisas para mim quando eu vou atender em numa consulta de enfermagem e eu não viso só a queixa do usuário, e eu dou a oportunidade para ele expor outras necessidades, agente trabalha como um todo.

Em determinada parte do curso, ocorreu uma situação com uma docente, e porque ela me escolheu, e me chamou para o corredor, para o corredor externo, no hospital o qual nós estávamos em estágio, estágio de prática, e me perguntou se eu não queria desistir do curso! E eu perguntei para ela porque, ela falou que eu tinha que pensar bem, se você quer mesmo fazer esse curso e eu perguntei para ela: 'Professora qual o motivo? A senhora acha que eu não tenho o perfil para o curso?'. 'Não, não, não, não é por isso não'. 'Porque já que vou fazer, que seja bem feito. Se a senhora quer saber, eu prestei vestibular pra enfermagem, e eu já tinha isso definido, e eu entrei como qualquer outro aluno, através de vestibular. E eu me vejo no direito de estudar até o fim'. E porque eu me refiro a isso como um ato de preconceito e por que eu vejo que sim. Porque na mesma semana, em seqüência das aulas práticas, de estágio, na prática como eu disse, ela veio me apresentar, uma chefe de enfermagem, que na época era bem colocado este termo, da UTI em que era uma mulata, com uma mulata, afrodescendentes, como eu. E aí, para mim foi onde caracterizou ainda mais, para mim, como um ato de um preconceito. E ela me colocou uma fala assim, "é eu estou te apresentando ela, para mostrar que eu não tenho preconceito'. Então não existia a necessidade de ela ter feito esta colocação. Para mim, eu entendi, como uma atitude de preconceito.

[Na escola] Teve outros episódios. Não só este. Foi de uma pessoa e especificamente, hoje eu até vejo assim, até como algo que contribuísse para minha maturidade, para que eu realmente me firmar-se dentro daquilo que eu escolhi, e independente da minha cor de pele, porque eu não sou a minha cor de pele, e sou uma pessoa como qualquer outra.

Por ser enfermeira acho que não [as coisas não seriam diferentes], eu acredito. Acho que esse episódio que ocorreu tenha sido uma coisa pessoal mesmo. Não da escola, mas da pessoa em si. 
[O número de alunos na sala] Não era igualitário. Havia eu e outra aluna que entrou e no meio do curso ela desistiu. [O por que não era igualitário] é uma pergunta que eu não tenho resposta.

Professor, que seja negro, bem, na escola de enfermagem, tinha um, na minha época, tinha um afrodescendente, deixe-me ver, não sei se até hoje ele continua lá, mais tinha um sim. A disciplina dele estava relacionada à pesquisa também. A disciplina dele estava relacionada à área de pesquisa, a disciplina em si, é porque ta distante. $\mathrm{O}$ nome é introdução à pesquisa? Não lembro, estava relacionada à pesquisa, era uma carga horária pequena que foi no último semestre. A grade curricular mudou, porque na minha época de aluna, nós estávamos pleiteando isso, a mudança de grade.

Como eu te disse acho que esse episódio [com a professora] foi muito pessoal, não devo relacionar com a escola como instituição, muito pelo contrário. Poxa como hoje eu sinto saudades, foi uma fase muito boa, muito boa, hoje eu falo e eu não sei se ainda continua. Hoje eu falo e me vem o jardim, que tem interno, sabe dentro? A gente ficava sentadinha, no horário de almoço, no local de encontro, no leme do local onde ficavam os nossos armários, o vestiário. Eu lembro com saudade, foram bons momentos que eu passei lá, com certeza, levo um saldo positivo, com certeza, tanto que me incentivou a continuar com os estudos.

[As atitudes racistas que sofri não se tornaram dificuldades] Porque a pessoa que você vê aqui dentro (gestos com um dedo da mão apontado para a cabeça) não tem cor, conhecimento não tem cor, então não existe. Aquele episódio, infelizmente, foi de uma pessoa. Eu acredito que acabou contribuindo comigo, é aquela história, se a vida te oferece um limão, faça dele uma limonada, e foi o que eu fiz e estou fazendo. Porque me incentivou a estudar cada vez mais. Tanto que tudo que eu quis fazer, eu fiz. Fiz a habilitação, e vou prosseguindo, e vou prosseguir. [Quero chegar] Até onde as minhas pernas me levarem, eu quero, eu pretendo é ser feliz. Porque quando eu falo em prosseguir, e isso eu aprendi quando aluna de nível médio, mas eu penso que ninguém é eterno. E gente, tudo aquilo, tudo o que é experiência que eu aprendi, a gente tem que multiplicar. E eu não quero levar comigo, muito pelo contrário, e o que era que as experiências que eu já tive, que sirvam para quem quiser prosseguir, que vá continuar, senão não adiantou nada. 
Entrevista em instituição particular, sim. Foi Tranquilo, porque foi o que te disse, conhecimento ele não vai, e ele não está relacionado com a cor de pele.

[O preconceito racial] $\mathrm{Na}$ sociedade com certeza existe, mas assim, depende da forma de como você vai encarar essa situação, de como você se põe na frente dela, porque se você encontra um obstáculo, como a cor de pele, e você recua, você está à centelha do veículo você começa a endossar esse, essa pensamento, e agora, se você se posiciona, independente da sua cor de pele, com seu conhecimento, que vão de colocar como obstáculo?

Eu não diria [que há a necessidade de], ter de fazer um esforço ainda maior, mais eu diria que você tem que estar mais instrumentada, não que isso gere um esforço maior, porque conhecimento te enriquece, existe sim, talvez eu não tive mesmo uma situação de preconceito e viva até por ser uma aluna da escola de enfermagem, o que já é uma seleção.

Eu gostaria de reforçar uma frase que eu acho que já falei várias vezes, eu acho que serei até bem repetitiva, o conhecimento não tem cor. Eu sempre lutei e luto para que as pessoas vejam a $X$, o que eu sou. Porque eu não sou o que você simplesmente, todas as pessoas, independente da cor de pele, começarem a ver isso, independente, porque é assim: a gente vai falar de uma pessoa e de repente, hoje a gente fala com a pessoa com relação ao afrodescendente, mas uma pessoa que, de repente, como um deficiente físico ou o nordestino. A pessoa tem que ver a pessoa, e quando digo a pessoa é a essência, e para mim é o mais importante.

\section{Colaborador 13}

Sou da etnia negra. [O mais correto é se referir a minha etnia como] Negros, pois brancos são chamados desta forma e ninguém se sente ofendido.

$\mathrm{Eu}$ escolhi enfermagem na segunda tentativa, pois na primeira tentei engenharia e passei na Unicamp. A enfermagem ainda é pouco reconhecida na sociedade como um todo e há até o preconceito de gênero, por eu ser homem em uma profissão ainda dominada amplamente por mulheres. [O que me motivou foi] $\mathrm{A}$ 
chance de ter uma profissão que eu pudesse ter um reconhecimento financeiro para ajudar a minha família. Eles me apoiaram.

[Entrei na EEUSP pelo] Vestibular universal no ano de 2000. Me formei em 2003. Fiz Licenciatura em Enfermagem, Residência em Enfermagem na UERJ e, 2005 e agora estou cursando o mestrado na EEUSP através do Programa Proesa a partir deste ano de 2007.

Não [concordo com as cotas para negros], pois esconde uma realidade, dando a falsa impressão que todos estão possuindo a mesma chance. Mas, a escola primária e secundária fica em segundo plano.

Sim [existe preconceito racial no Brasil] é um preconceito mascarado. Quando você está no meio social, as pessoas conversam no mesmo grau de condições com você, mas quando você não está com essas pessoas elas te criticam e falam mal de você. [Podemos combatê-lo] mostrando a toda a sociedade que as pessoas recebendo as mesmas condições de igualdade, conseguem se desenvolver, independente da cor da sua pele ou classe social pertencente.

[Já o vivi] Em entrevistas de emprego. Antes de mencionar a qual cargo eu compareci na agência as recepcionistas já me encaminharam para as vagas de ajudante geral e segurança. Ambas as profissões tão dignas quanto a minha. O problema está no pré-julgamento.

Infelizmente, sempre percebo [um tratamento diferenciado]. Hoje sou o responsável pela supervisão de um Centro Cirúrgico, mas quando alguém vai me procurar no setor e não me conhece ficam esperando outra pessoa. Então, quando eu me apresento às pessoas ficam pensativas e um pouco sem jeito. [Senti preconceito na graduação de] Algumas alunas no início da graduação, [através de] Comentários que uma menina da nossa classe não poderia namorar comigo devido o fato de eu ser negro e ela branca.

A minha classe possuía três negros de um total de 75 alunos. Em toda graduação só tive uma única docente negra. Eu não me recordo de ter assistido aula de um docente negro.

Sim [acho que ser um homem negro na enfermagem contribuiu para a ocorrência de atitudes preconceituosas], ambas [racial e sexista]. [Eu senti] No 
processo de seleção de um grande hospital de São Paulo, por profissionais que trabalhavam na instituição. Eu fui barrado na recepção do Departamento pessoal. Pois anunciaram que os candidatos a enfermeiro júnior poderiam comparecer a uma determinada sala. Então, as pessoas se dirigiram ao local e eu fui barrado. Alegaram se eu não havia ouvido que a vaga era para enfermeiros recém-formados na USP e não para segurança. A seleção para segurança seria realizada em outra sala. Eu concordo que possa haver esta segmentação racial. Esta pré-seleção é, infelizmente, feita.

\section{Colaboradora 14}

Eu me considero negra. Me formei em 1996, eu acho. Logo depois de me formar eu fui trabalhar num home care, mas eu fiz especialização em UTI e pretendo fazer outra em obstetrícia. [Atuo como enfermeira]. Eu trabalhei no home care por alguns anos, mas hoje eu trabalho em um hospital particular no interior do Estado.

Eu acho que sim [minha família apoiou a decisão]. Bom, meus pais me apoiaram e, depois que eu passei na USP, acho que eles apoiaram mais ainda. Mas a enfermagem não foi minha primeira opção. Eu queria fazer medicina, mas eu não passei. Olha, eu vou ser bem sincera. Eu queria mesmo era fazer medicina, mas depois de uns dois anos de cursinho você acaba tentando outras coisas. Aí, eu achava que era tudo meio parecido, naquela época, e acabei prestando enfermagem e passando. Foi isso. E depois você acaba se apaixonando pela profissão e tal, então você acaba ficando. E vai vendo as diferenças.

$\mathrm{Eu}$ acho que existe sim [preconceito racial no Brasil]. Eu já fui vítima de preconceito algumas vezes. Mas nem todo mundo acha que existe. Nem todo mundo vê.

Já [fui vítima de preconceito]. Principalmente quando eu trabalhava no home care. As pessoas vêm uma negra chegar na casa delas e acham que você é técnico de enfermagem. Aconteceu mais de uma vez. Mas elas não me trataram mal, só assumiram logo de cara que, por eu ser negra, eu deveria ser técnica, entende? No 
hospital também aconteceu a mesma coisa. Mas você se apresenta de uma outra forma e explica quem você é. E quando você diz que se formou na USP, pronto, ninguém mais duvida de que você é mesmo a enfermeira.

Como aluna, eu acho que não [sofri nenhum preconceito]. Não assim, de cara, entende? A gente sente que alguns colegas ficam mais afastados, não convidam você pra trabalhar no grupo deles e coisas desse tipo. E não tem como explicar se não porque eles têm preconceito com a sua cor. Porque uma coisa é você não gostar de alguém porque, sei lá, vocês não se dão bem, as idéias não batem, mas outra é você nunca tentar nem conhecer aquela pessoa, nem conversar. Assim, sem nenhum motivo aparente. Dos professores eu já não sei. Eu acho que não. Porque eles têm que tratar todo mundo igual, é dever deles, então eu acho que não. Nunca aconteceu.

Eu acho que a maioria dos funcionários também são negros, não são? Pelo menos, pelo que eu lembro, eles eram. Então é meio difícil um negro ter preconceito com outro negro. Por isso eu acho que não [sofri preconceito por parte deles]. Comigo nunca aconteceu.

Eu não sei se é pra provar o nosso valor [que o negro tem que trabalhar mais pra chegar no mesmo degrau que o branco], mas, com certeza, a gente precisa de um esforço maior pra chegar, sei lá, no mesmo cargo, por exemplo. Como eu te disse antes, as pessoas, de primeira, não acreditam que você, por ser negra e tal, conseguiu se formar na USP, ou entrar na faculdade. É um pré-julgamento baseado apenas na sua cor. Naquilo que elas acham que qualquer pessoa com as suas características conseguem ou não fazer. Então, eu acho que a gente precisa provar mais pros outros que a gente consegue, entende? Porque eles já acham que você não é capaz. Não é todo mundo, mas, uma grande parte das pessoas ainda acha que todo negro é pobre e sem futuro. E não é bem assim. Acho que as pessoas precisam de oportunidades. E os negros que tem essas oportunidades precisam fazer bom uso delas. As pessoas precisam ver que nós somos tão capazes quanto qualquer um. Só assim eu acho que elas vão nos respeitar, aceitar, entende? Mas pra isso, as pessoas que podem tem que dar uma oportunidade, senão, não faz diferença o negro ir pra faculdade se depois ele não consegue um bom emprego, uma boa chance. Então, eu acho que precisa de uma série de coisas, mas a primeira é oportunidade. 


\section{UNIVERSIDADE DE SÃO PAULO ESCOLA DE ENFERMAGEM}

Av. Dr. Enéas de Carvalho Aguiar, 419 - CEP 05403-000 Tel.: (011) 3061-7548/8858 - Fax: (011) 3061-7548 São Paulo - SP - Brasil e-mail: edipesq@usp.br

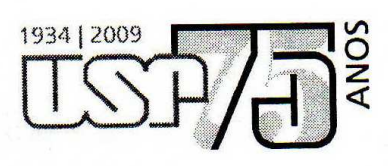

São Paulo, 02 de março de 2009.

$\mathrm{Ilm} .{ }^{\circ} \mathrm{Sr}$.

Prof. Dr. Genival Fernandes de Freitas

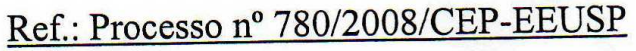

Prezado Senhor,

Em atenção à solicitação referente à análise do projeto "Ser enfermeiro negro na perspectiva da transculturalidade do cuidado", informamos que o mesmo foi considerado aprovado pelo Comitê de Ética em Pesquisa da Escola de Enfermagem da Universidade de São Paulo (CEP/EEUSP).

Analisado sob o aspecto ético-legal, atende às exigências da Resolução $n^{\circ}$ 196/96 do Conselho Nacional de Saúde.

Esclarecemos que após o término da pesquisa, os resultados obtidos deverão ser encaminhados ao CEP/EEUSP, para serem anexados ao processo.

Atenciosamente,

$$
\text { Mania fat fermandes. }
$$

Prof. ${ }^{\mathrm{a}} \mathrm{Dr}{ }^{\mathrm{a}}{ }^{\mathrm{a}}$ Maria de Fátima Prado Fernandes

Coordenadora do Comitê de Ética em Pesquisa da

Escola de Enfermagem da Universidade de São Paulo 


\section{ANEXO B}

\section{UNIVERSIDADE DE SÃO PAULO \\ ESCOLA DE ENFERMAGEM}

Av. Dr. Enéas de Carvalho Aguiar, 419 - CEP 05403-000

Tel.: (011) 3061-7548/8858 - Fax: (011) 3061-7548 -

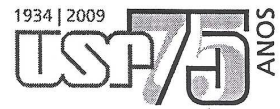

São Paulo - SP - Brasil

São Paulo, 22 de maio de 2009.

$\mathrm{Ilm} .^{0} \mathrm{Sr}$.

Genival Fernandes de Freitas

Prezado Senhor,

Nos termos da documentação contida no processo $n^{0}$ 97/2009/CPq/EEUSP, informamos que V.S ${ }^{\text {a }}$ foi autorizado a realizar, nesta Unidade, a coleta de dados relativa ao projeto de pesquisa "Ser enfermeiro negro na perspectiva da transculturalidade".

Atenciosamente,

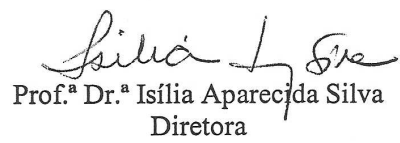

